DEPARTMENT OF THE INTERIOR

UNITED STATES GEOLOGICAL SURVEY

GEORGE OTIS SMITH, DIRECTOR

BULLETIN 605

ASVESLLED

\title{
THE ELLAMAR DISTRICT, ALASKA
}

BY

S. R. CAPPS

AND

B. L. JOHNSON

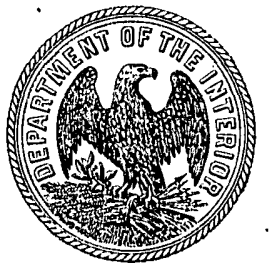

WASHINGTON

GOVERNMENT PRINTING OFFIOE 



\section{CONTENTS.}

Location......................................... 9

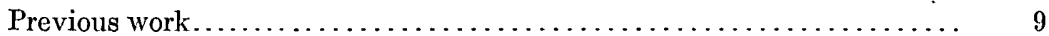

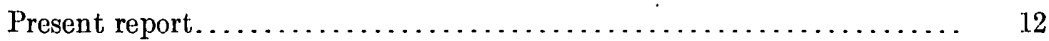

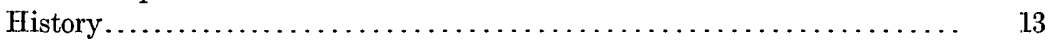

Geography, by S. R. Capps.................................. 14

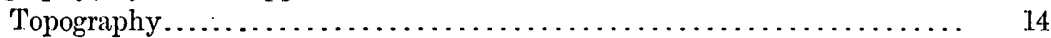

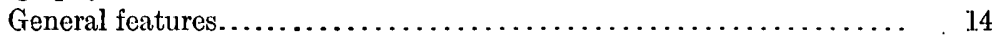

Influence of rock structure on topography.................... 16

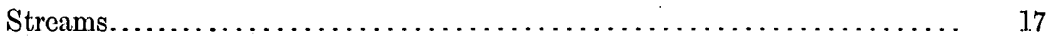

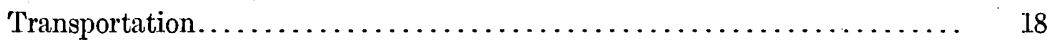

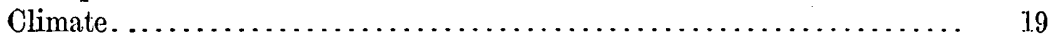

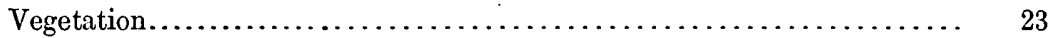

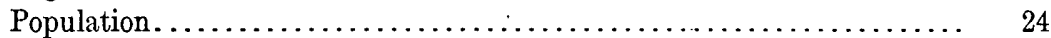

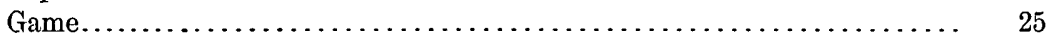

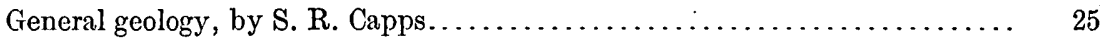

Divisions of the rocks......................................... 25

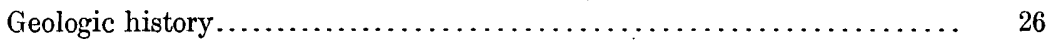

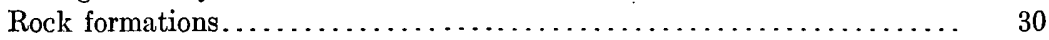

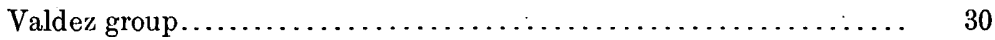

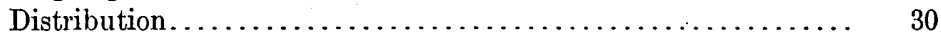

Character.......................................... 31

Structure........................................ 33

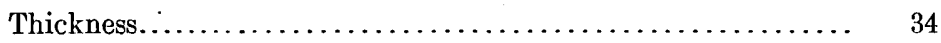

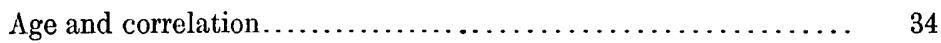

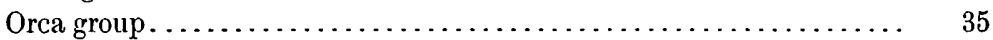

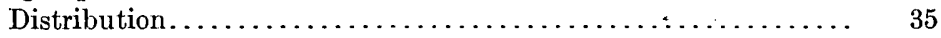

Character...................................... $\quad 36$

Lithologic divisions............................ 36

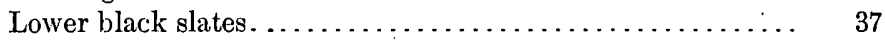

Lower slates and graywackes. . . . . . . . . $37 \ldots \ldots \ldots \ldots . \ldots \ldots \ldots \ldots$

Greenstones.................................... 39

Occurrence................................ 39

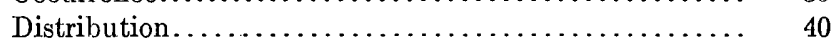

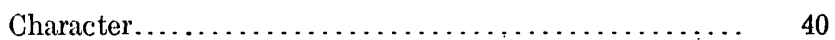

Conglomerate................................. 42

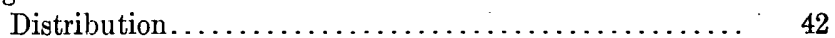

Character.................................. 42

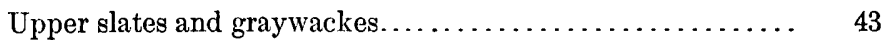

Structure........................................ 44

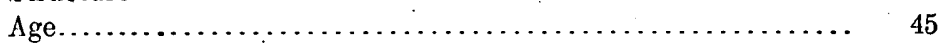

Quaternary deposits................................ 46

Glaciation........................................ 46

Unconsolidated deposits............................. $\quad 47$

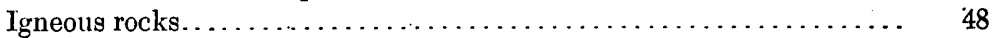




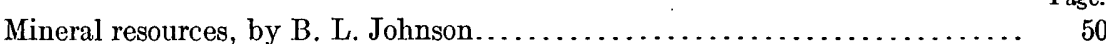

Metals present.............................................. 50

Geographic distribution of the deposits....................... 50

Prince William Sound mineral belts........................ 50

Relation of Ellamar district to Prince William Sound mineral belts. . 50

Distribution of mineral deposits within the Ellamar district........ 51

Production ......................................... $\quad{ }_{2}$

Literature.......................................... 52

Geologic distribution and relations of the mineral deposits............. 62

General features...................................... 62

Structural relations. . . . . . . . . . . . . . . . . . . .

Distribution of fissuring and faulting...................... $\quad 62$

Relation of fissuring and faulting to structure............... 63

Type of faulting.................................... $\quad 63$

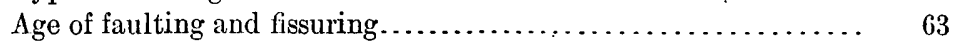

Fissure systems................................... 64

Relation of the ore deposits to fissuring................... 64

Relation of the mineral deposits to the country rock.............. 65

Character of the ore deposits................................ 66

Ore minerals.............................................. 68

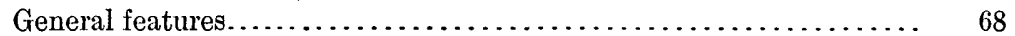

Paragenesis of sulphide ore minerals ........................ $\quad 71$

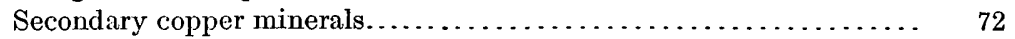

Genesis of the ores........................................... 73

Value and scope of the discussion. ....................... 73

Periods of mineralization in Prince William Sound region........... 73

Deposition of the ores.................................. $\quad 75$

Composition of the ore-bearing solutions...................... 78 .

Course of the ore solutions.................................. 78

Source of the metallizing solutions....................... $\quad 79$

Source of the copper and other metals....................... 80

Time of metallization.................................. 82

Relation of the ore deposits to intrusive rocks $\ldots \ldots \ldots \ldots \ldots \ldots \ldots \ldots .83$

Relation of the mineral deposits of the Ellamar district to metallogenetic

epochs and provinces................................. 84

Mines and prospects of Ellamar district.......................... 87

Copper mines............................................ 87

Ellamar mine......................................... 87

Location........................................ 87

History and development.......................... 87

Equipment....................................... 88

Method of mining and ore treatment................... 89

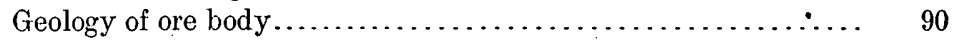

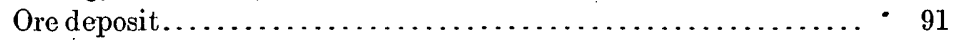

The ore........................................ 91

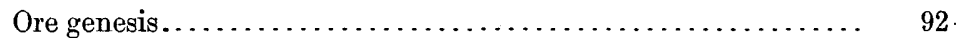

Threeman Mining Co.'s mine.............................. 92

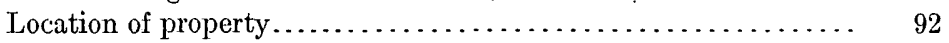

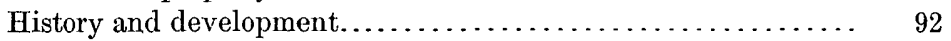

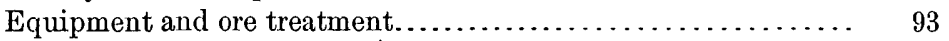

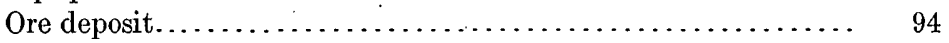

Landlock Bay Copper Mining Co....................... 96

Location of property................................ 96

History and development.......................... 96 
Mines and prospects of Ellamar district-Continued.

Copper mines-Continued.

Landlock Bay Copper Mining Co._Continued. Page.

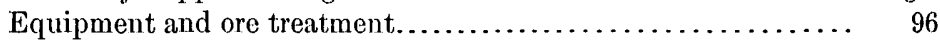

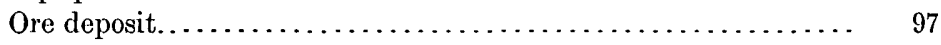

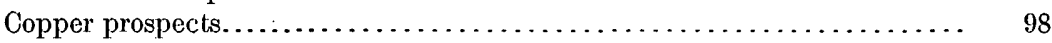

Banta \& Cameron prospect.................................. 98

Fielder \& Hemple prospect................................ 98

Prospects of Galena Bay Mining Co....................... 98

Location. . . . . . . . . . . . . . .

History and development. . . . . . . . . . . . .

Equipment. .................................... 100

Ore deposits......................................... 100

Prospects of Reynolds Alaska Development Co.............. 102

Prospects of L. P. M. Falck ............................. 103

Standard Copper Mines Co............................... 104

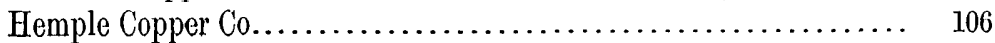

Prospects of Threeman Mining Co......................... 107

Workings of Alaska Commercial Co...................... 107

Montezuma claim.................................. 108

Claims on south side of Landlocked Bay................. 109

Workings on Fish Bay side of Billy Goat Mountain......... 109

Alaska, Pioneer, and Sourdough fractions..................... 110

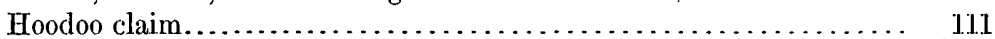

Chisna Consolidated Mines Co........................... 111

Gold quartz prospects..................................... 112

Mines and prospects on Port Fidalgo......................... 112

Fidalgo Mining Co......................................... 113

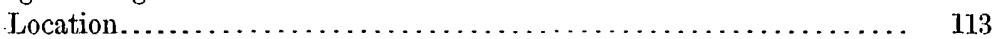

History and development.................................. 113

Equipment and ore treatment........................... 114

Ore deposit....................................... 114

Fidalgo-Alaska Copper Co................................. 117

Location............................................ 117

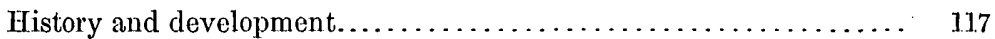

Equipment and ore treatment.............................. 118

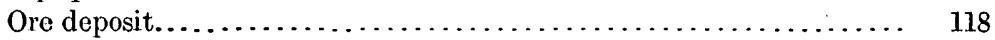

Dickey Copper Co...................................... 120

Location......................................... 120

History and development............................. 120

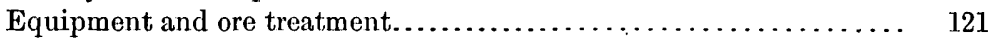

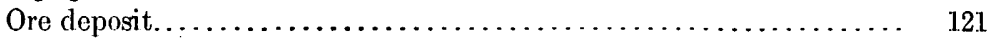

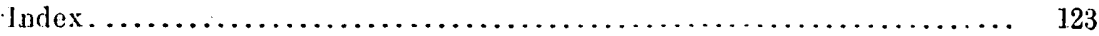




\section{ILLUSTRATIONS.}

Prate I Topographic map of Ellamar district . Page.

II. Geologic map of Ellamar district..................... In pocket.

III. Copper Mountain from the north, looking across the head of Vesuvius Valley.......................................... 14

IV. Boulder Bay from the south............................ 15

V. $A$, Steeply dipping slate and graywacke beds of the Valdez group; $B$, Slates and graywackes of the Orca group conformably overlain by diabase flows................................... 38

VI. $A$, Cross section of ellipsoidal greenstone bed near Rocky Point; $B$, Ellipsoidal greenstones in section and plan near Rocky Point......

VII. $A$, Irregular-shaped forms of ellipsoidal greenstones in plan, east end of Bligh Island; $B$, Shale interbedded with ellipsoidal greenstone.

VIII. $A$, Ellipsoidal greenstone succeeded by conglomerates and shales, which are themselves overlain by lava flows; $B$, Volcanic breccia on north side of Galena Bay near mouth....................

IX. $A$, Tilted and slightly folded slates and graywackes of Orca group, on the southeast side of Bligh Island; $B$, Coarse massive phase of conglomerate of Orca group near Rocky Point..................

X. $A$, Ellamar mine; $B$, Ore body of Ellamar mine, exposed in glory

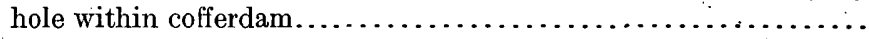

Figure 1. Index map showing relation of Ellamar district to.Prince William

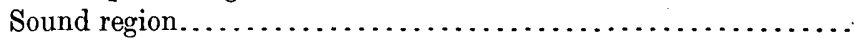

2. Sketch map showing distribution of timber in Ellamar district....

3. Generalized columnar section of the rocks of Ellamar district.......

4. Relations between ellipsoidal greenstone flows and interbedded sediments.................................... 40

5. Strike of fissures in Ellamar district..................... 64

6. Plan of underground workings of Ellamar mine.............. 89

7. Plan of underground workings on Keystone claim, Threeman Mining Co., Landlock, Alaska............................

8. Sketch plan of main underground workings of Landlock Bay Copper

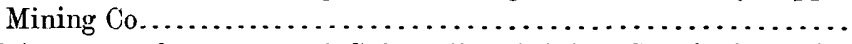

9. Claim map of property of Galena Bay Mining Co., in Vesuvius

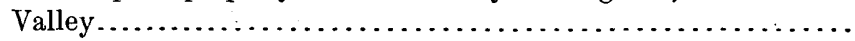

10. Sketch map showing location of properties of Fidalgo Mining Co., Fidalgo Alaska Copper Co., and Dickey Copper Co. on Port

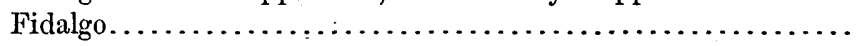




\section{PREFACE.}

\section{By Alfred H. Brooks.}

Reconnaissance surveys of Prince William Sound, begun in 1898 and continued from time to time, were completed in 1908 . These investigations have indicated the general distribution of the mineral resources and something of the larger geologic features. Meanwhile the advancement of both gold and copper mining made evident the need of more detailed information, and for this reason the survey of the Ellamar district here set forth was made. Studies of the other important mining localities are planned, but to carry out such a plan it.is necessary to make detailed topographic base maps. The topographic map of Port Valdez district was completed in 1912 and the geologic survey and study of mineral resources was begun in 1914.

The study of the Prince William Sound region indicates that its geology is so complex that it can be mastered only by a detailed survey. This report is the first result of a series of such surveys planned. The results presented show a decided advance on those of the reconnaissance surveys, but it must be remembered that the survey of one small area, especially in the absence of any paleontologic evidence, may not yield a definite clue to the stratigraphic sequence. The survey of the Ellamar district confirms the previous larger grouping of the formations into the Valdez and Orca groups. As was expected, it also indicates that both these groups may be divided into smaller stratigraphic units. In this report the Orca group has been so subdivided. These formations are not named in this report because they are not yet sufficiently well defined to give assurance that they will have a permanent place in geologic literature.

Mr. Johnson, who is in large measure responsible for the account of the ore deposits in this volume, has arrived at somewhat different conclusions in regard to their origin from those reached by previous investigators. The occurrence of the ores in zones of fracture and shearing along fault planes is established, and Mr. Johnson has proved that the ore bodies, in part at least, are replacements of the crushed rock. Many of the facts presented indicate that the ores are in large part due to such replacement. Evidence is also adduced to show 
that the greenstone is not the source of the copper, as has been suggested by other investigators. Mr. Johnson has made the deduction from the facts in hand that both the copper and the gold mineralization of the Prince William Sound region belong to the same general epoch and are connected with the granitic intrusives. This conclusion seems to be in accord with what is known of other parts of the coastal mining belts of Alaska, notably those of the southeastern part of the Territory. It must be noted, however, that the evidence of any direct genetic relation between the mineralization of the Prince William Sound region and the granitic intrusions is far from being complete, so that this theory should for the present be regarded. as only tentative.

It is believed that this detailed study of the geology and ores of the Ellamar district will contribute to a better knowledge of the occurrence of mineral deposits in the Prince William Sound region, which are receiving further study. This region is now one of the large copper producers of Alaska and promises to continue to hold this position. Its strong relief and its accessibility to tidewater make for cheap mining. When the coking coals of the Bering River or Matanuska field are made available a local smelting industry would seem to be assured. 


\title{
THE ELLAMAR DISTRICT, ALASKA.
}

\author{
By S. R. Capps and B. L. Johnson.
}

\section{INTRODUCTION.}

\section{IOCATION.}

The mining district in the vicinity of Ellamar lies at the northeast border of Prince William Sound and includes a part of the mainland, about half of Bligh Island, and a number of smaller islands. Prince William Sound is a large embayment in the north-central part of the Gulf of Alaska, which is that part of the north Pacific Ocean that is inclosed by the great crescent of const line between Kodiak Island and Sitka. The area covered by this report lies between latitude $60^{\circ} 52^{\prime}$ and $60^{\circ} 58^{\prime} \mathrm{N}$. and longitude $146^{\circ} 29^{\prime}$ and $146^{\circ} 51^{\prime} \mathrm{W}$., and includes about 65 square miles of land. Its position with relation to Prince William Sound as a whole is shown in figure 1.

The area shown in the topographic map (Pl. I, in pocket) is here called the Ellamar district, Ellamar being the oldest and largest white settlement within it and the Ellamar mine one of the oldest and most productive mines on the sound and the most effective agency in bringing this district into prominence. The district as here mapped includes the shores of Landlocked, Boulder, Virgin, and Galena bays and Tatitlek Narrows, and the northeastern half of Bligh Island. Earlier maps of this area, showing the shore line and something of the topography, have already been published, but they have all been on a relatively small scale, and were drawn primarily for use in navigation. The topographic map that accompanies this report (Pl. I), on a scale of 1 to 62,500 , is by far the most accurate and complete map yet published of the area which it covers and shows not only the relative position of the land and water but the shape of the land surface. It has been used as the base for the geologic map (Pl. II).

PREVIOUS WORK.

The shore of Prince William Sound was one of the first parts of the main body of Alaska to be charted. Many navigators visited this region in the last part of the eighteenth century, and since the 
transfer of Alaska to the United States in 1867 the United States Coast and Geodetic Survey has been constantly engaged in mapping the coastal region. It was not until 1891, however, that the first

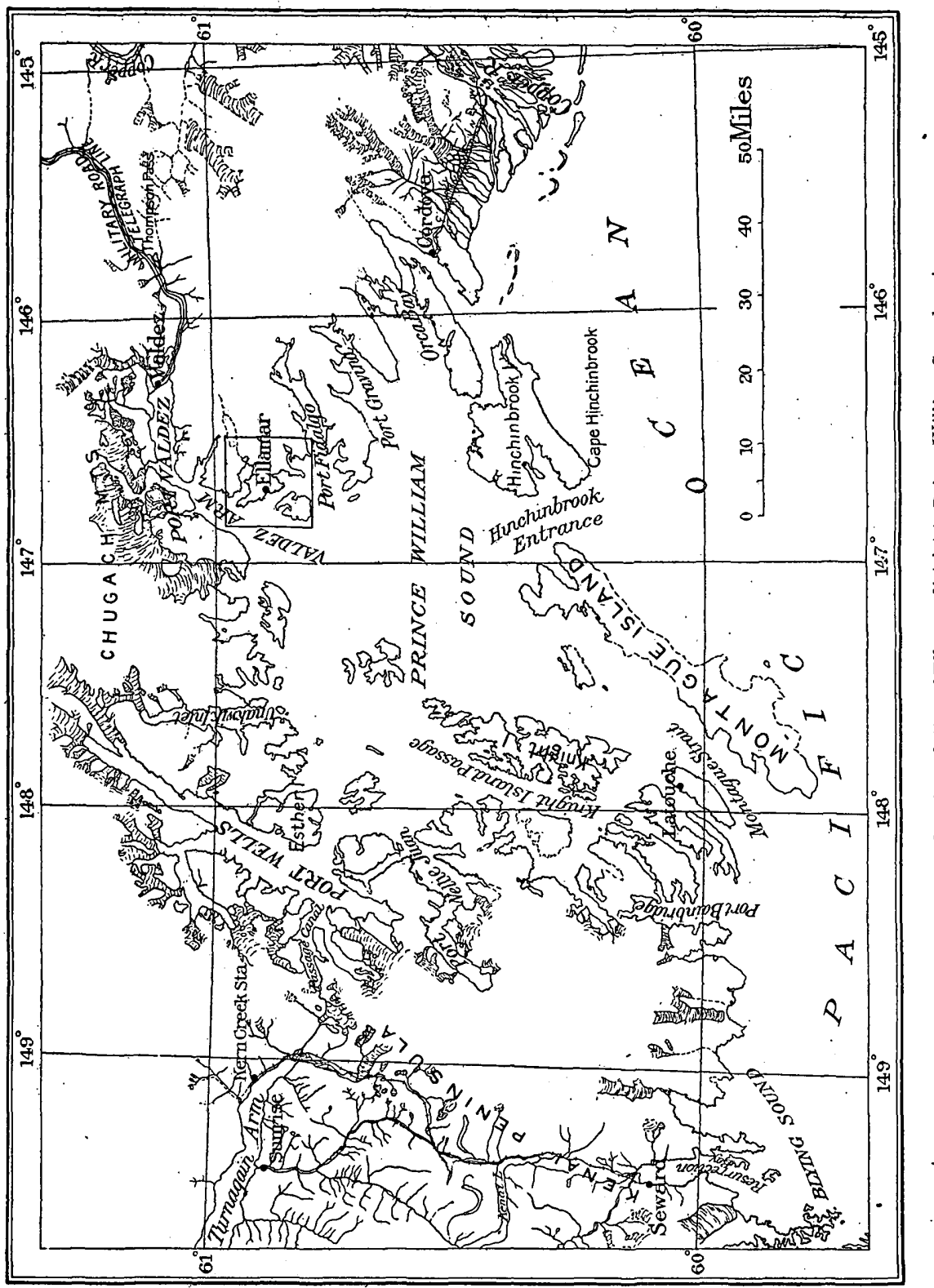

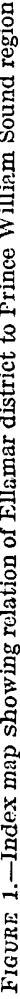

geologist entered this field. In that year C. W. Hayes, ${ }^{1}$ after having finished an exploratory trip into the interior, spent a few days on Prince William Sound and recorded some observations on the rocks

1 An expedition through the Yukon district: Nat. Geog. Mag., vol. 4, p. 142, 1892. 
of that region. In 1898 Mendenhall, ${ }^{1}$ in a trip from Port Wells to Turnagain Arm and thence up Matanuska River, crossed the Chugach Range and reported on the geology along his route. In the same year Schrader ${ }^{2}$ made a geologic study of parts of the shore between Orca and Valdez, in the course of which he subdivided the rocks into two main groups. In 1899 the geologists of the Harriman Alaska expedition visited a number of points on the shores of Prince William Sound and gave their conclusions in the reports of that expedition. ${ }^{3}$ In 1900 Schrader and Spencer ${ }^{4}$ spent several weeks between Orca and Rocky Point, adding to the previous knowledge of the geology of this area. Grant ${ }^{5}$ spent portions of the summers of 1905, 1908, and 1909 in reconnaissance geologic work in Prince William Sound and each year published a brief account of the results of his investigations. A much more complete report by Grant and Higgins, ${ }^{6}$ embodying the results of field work done during the summers of 1905, 1908, and 1909 has been published. These investigators spent considerable time in the copper-bearing district near Ellamar, and their report upon the development of that district was complete up to 1909. Their field, however, was broad, covering 2,000 miles of coast line on the mainland and islands of the sound, and their published conclusions in regard to the relations of the different rock groups were generalized to fit the conditions found throughout the whole region in which they worked. Their notebooks contain much information concerning details of structure and relations which found no place in the reconnaissance report published. Moffit ${ }^{7}$ gathered some notes on the developments in the sound region in 1907, without himself visiting the field. In 1911 Brooks $^{8}$ spent a short time in examining the gold quartz and in studying the geology of Port Valdez. The field of his study, however, so far as known, all lay within the rocks of the Valdez group.

In addition to the reports published by the United States Geological Survey there have appeared from time to time in technical magazines short reports by several geologists and engineers on mining conditions and the character of the ore deposits, but these have been

1 Mendenhall, W. C., A reconnaissance from Resurrection Bay to the Tanana River, Alaska, in 18@8: U. S. Geol. Survey Twentieth Ann. Rept., pt. 7, pp. 26i5-340, 1900.

2 Schrader, F. C., A reconnaissance of a part of Prince William Sound and the Copper River district, Alaska, in 1898: Idem, pp. 341-423.

3 Farriman Alaska Expedition, vol. 4, 1904.

${ }^{4}$ Schrader, F. C., and Spencer, A. C., The geology and mineral resources of a portion of the Copper River district, Alaska: U. S. Geol. Survey special pub., 1901.

5 Grant, U. S., U. S. Geol. Survey Bull. 284, pp. 78-87, 1906. Grant, U. S., and Higgins, D. F., U. S. Geol. Survey Bull. 379, pp. 87-9€, 1909. Grant, U. S., U. S. Geol. Survey Bull. 379, p. 97, 1949. Grant, U. S., and Higgins, D. F., U. S. Geol. Survey Bull. 442, pp. 161-165, 1910.

6 Grant, U. S., and Higgins, D. F., Reconnaissance of the geology and mineral resources of Prince William Sound, Alaska: U. S. Geol. Survey Bull. 443,.1910.

${ }^{7}$ Moffit, F. J., Notes on copper prospects of Prince William Sound: U. S. Geol, Survey Bull. 3iti, pp. $176-178,1908$.

8 Brooks, A. H., Gold deposits near Valdez: U. S. Geol. Survey Bull. 520, pp. 108-130, 1912. 
discussions of particular phases of the subject, 'without attempt to correlate the facts over any considerable area.

\section{PRESENT REPORT.}

With the exception of Brooks's work near Valdez in 1911, the efforts of all the earlier geologists who have been in this field have been directed to the mapping of large areas and to the separation of the rocks of the Prince William Sound region into their larger stratigraphic divisions. The size of the areas which they surveyed within the limits of the field seasons made it necessary for them to neglect details at many interesting localities for the sake of determining the areal extent of the larger stratigraphic units. More or less active prospecting on the sound during the last 15 years has shown that although copper-bearing minerals are widely distributed through the rocks of the Orca group, commercial bodies of ore have been found only within rather.small areas. One of the most promising of these areas lies on the mainland within a few miles of the village of Ellamar. The steady production for a number of years from one mine at Ellamar and the recent placing of two other mines at Landlocked Bay on a productive basis have given this district some prominence as a copper producer. It therefore seemed desirable to obtain more detailed information about the geology and ore deposits of this area, to examine the more recent mining developments, and to map as far as possible the several rock formations in the hope of clearing up some of the problems concerning the origin and relations of the ore deposits and the stratigraphic succession of the rocks in the Prince William Sound region. With this end in view a topographic party in charge of $\mathrm{R}$. H. Sargent, assisted by C. E. Giffin, was detailed to map an area including the territory adjacent to Landlocked, Boulder, Virgin, and Galena bays and Tatitlek Narrows. To the writers was assigned the task of mapping the areal geology and studying the ore deposits of the same area. Owing to the late date at which the appropriation for this work was made by Congress the field work was not begun until August 25, 1912 , and bad weather forced it to an end on October 17. In this short season a topographic map of about 65 square miles was completed, all the important mines and prospects were visited and studied, and the surface distribution of the principal rock formations was determined as far as the time and field conditions would permit. The combination of extremely bad weather, dense vegetation, and complicated geologic structure rendered it impossible to trace out all the contacts with the degree of accuracy that would have been maintained under more favorable conditions, but it is believed that, so far as it covers areas where good exposures were obtainable, the 
map is not far in error. In the geologic field work the writers spent some time in both areal mapping and in study of the ore deposits. Mr. Johnson spent most of his time in the field in studying the ore deposits, and his office work included the description of mines and prospects, the discussion of the problems of economic geology, and the description of the mineral resources. Mr. Capps prepared the other parts of this report and the geologic map. In the field he devoted the greater portion of his attention to the areal mapping and to the study of the geologic structure. A short.summary of the results of this investigation has already been published. ${ }^{1}$ In 1913 B. L. Johnson spent several months in geologic work in the Prince William Sound region, during which time he revisited a number of localities in the Ellamar district. Some of the mining developments which took place during the winter of 1912-13 are therefore described in this report, as are also some mining properties on Port Fidalgo which had not been previously visited.

\section{HISTORY.}

In the years prior to 1897 scant attention was given to the search for valuable minerals in the Prince William Sound region, and so far as can be learned, no claims had been staked. Indications of copper ore, it is said, were first discovered in 1897, when Louis Jacobson, while fishing in Landlocked Bay, saw copper stains on the rocks near the shore and found copper float near by. A claim, afterward acquired by the Alaska Commercial Co., was staked early that spring. Soon afterward M. O. Gladhaugh and C. Pederson were led by the natives to the ore croppings in Virgin Bay and located the Gladhaugh ore body, which afterward became the Ellamar mine. In July, 1897, Gladhaugh and A. K. Beatson, with several associates, were shown the Bonanza ore body on Latouche Island, and staked claims there. These were the first bodies of copper ore to be located by white men on the sound, although it is reported ${ }^{2}$ that the Bonanza ore body had been worked by the natives for native copper and for paint materials long before the advent of the white man. Large numbers of stone hammers that were found deeply buried in the soil near this place had evidently been used by the Indians to pound the native copper from the rock.

In 1897 reports of the fabulous richness of the discoveries in the Klondike were widely circulated by the press throughout the world, and in the fall of that year began the great stampede which reached its height in 1898. The Valdez Glacier was known to offer a possible

\footnotetext{
${ }^{1}$ Capps, S. R., and Johnson, B. L., Mineral deposits of the Ellamar district: U. S. Geol. Survey Bull. 542, pp. 86-124, 1913.

2 Lincoln, F. C., The Big Bonanza copper mine, Latouche Island, Alaska: Econ. Geology, vol. 4, pp. 201-213, 1909.
} 
route through the coastal mountains, and the pass was chosen by several thcusand gold seekers whose destination "was anywhere in "the interior," beyond the Chugach Mountains. In the fall of 1897 and the spring of 1898 the town of Valdez came into existence, and although most of the prospectors spent their energies in crossing the glacier, a few took the opporturity to prospect along the coast. Since that time prospecting has been carried on more or less vigorously on the sound each year. The first copper ore to be shipped for smelting came from the Bonanza mine in 1899, and the Ellamar mine made its first shipment in 1900 and has shipped ore regularly every year since. Interest in the search for copper mines increased from year to year and culminated in 1906 and 1907, when great numbers of claims were staked and active plans for development were made. The financial stringency in the fall of 1907 caused most of these plans to be abandoned, and in more recent years development has been attempted on only a few of the more promising discoveries. The Threeman Mining Co. claims, in Landlocked Bay, were staked in 1903. In 1904 and 1906 small sample shipments of ore were made, but it was not until the fall of 1911 that regular shipments were made from the mine. In 1912 the Landlock Bay Copper Mining Co. made a small shipment of ore, and two or three other companies on the sound give promise of producing ore in commercial quantities in the near future.

\section{GEOGRAPHY.}

By S. R. CAPPS.

TOPOGRAPHY.

\section{GENERAL FEATURES.}

The district in the vicinity of Ellamar, as well as all the Prince William Sound region, lies along the southern border of the Chugach Mountain Range. The area is one of high relief, as in most places the mountains rise steeply from the shores. Copper Mountain, the highest peak near Ellamar, has an elevation of 3,860 feet, although its top is only four-fifths of a mile from the beach. (See Pl. III.) Eight miles northeast of Copper Mountain but outside the area with which this report is concerned is Mount Denson, locally known as the "Rooster Comb," which reaches a height of 5,886 feet. Ellamar Mountain, the most prominent peak between Galena Bay and Tatitlek Narrows, is 3,050 feet high. Farther north, toward the main axis of the Chugach Range, the peaks are progressively higher, many of them rising above 7,000 feet. Between Port Valdez and Port Wells there may be seen, in clear weather, a high snow-covered mountain mass, which is unsurveyed but which probably does not fall short of 10,000 feet in elevation and may be even higher. As 


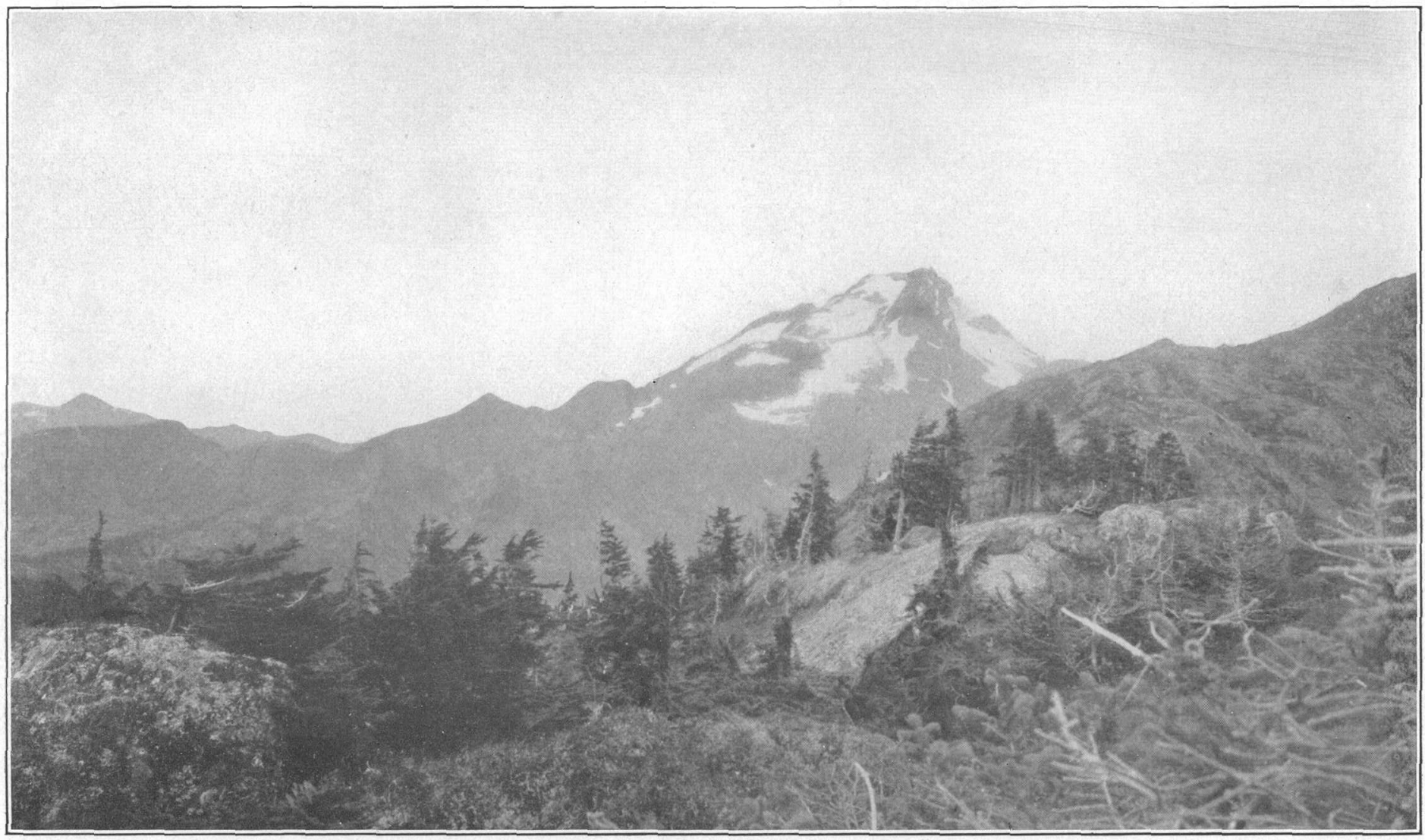




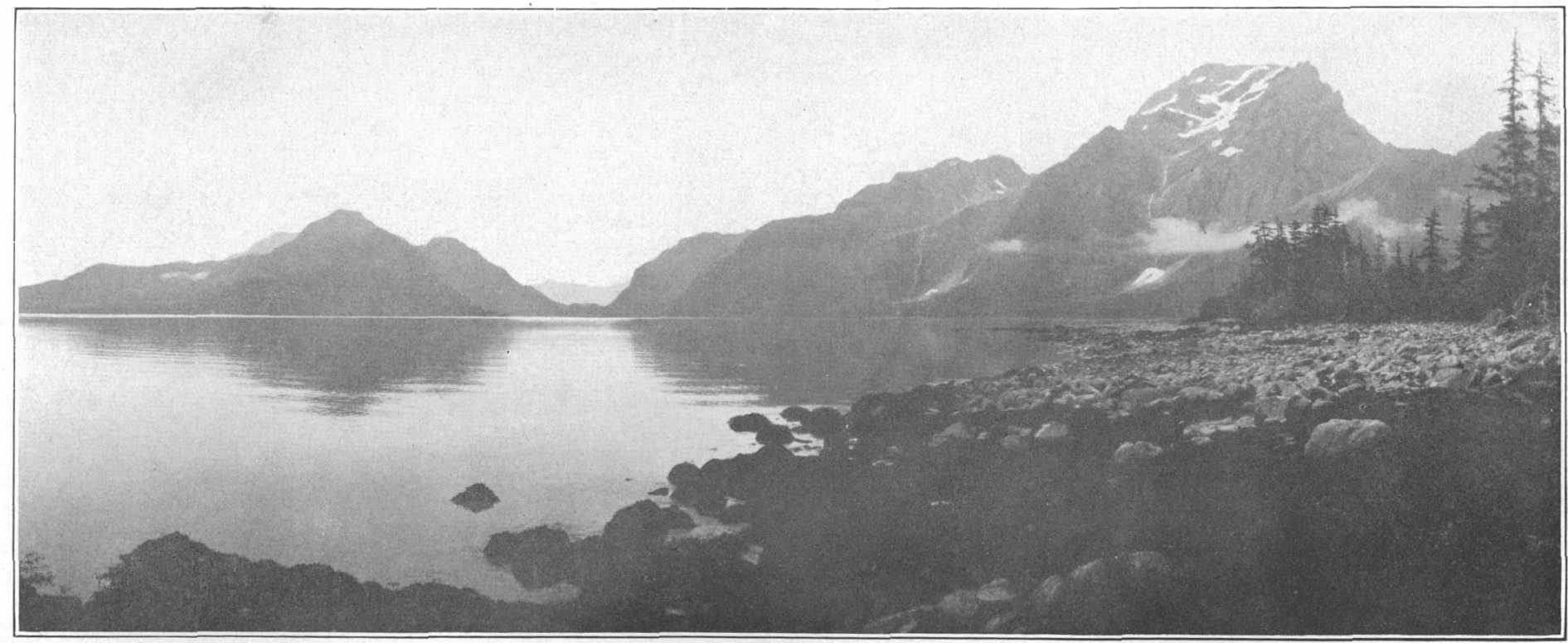

BOULDER BAY FROM THE SOUTH.

Copper Mountain on the right and the low gap between Boulder and Galena bays near the center. 
seen from a distance most of the peaks of the range seem to have a certain accordance of elevation, although the tops of many of the higher mountains stand above this general level. Grant ${ }^{1}$ and others have interpreted this summit level as suggesting an ancient peneplain that had been elevated far above sea level, warped, and eroded. To the writers it seems that more detailed study than has been given in this region is required to justify such an interpretation. In any wide mountain range containing a multitude of peaks the sky line as seen from a sufficient distance appears more or less uniform and level. Here there are many peaks that rise above the general level and wide areas in which none reach it, and so far no uneroded remnants of the old plain have been found. Many agencies that are active in the denudation of mountain regions in high latitudes and that tend to reduce the higher mountains with great rapidity are much less effective at lower altitudes, so that the tendency of normal erosion is to bring down the projecting peaks toward the general level of the whole range and to produce a somewhat even sky line. The presence of an ancient peneplain in the Chugach Mountains is therefore still open to question. In the district around Ellamar erosion has been so extensive that all suggestions of this peneplain are lacking.

The coast line in the vicinity of Ellamar is very irregular, as is that of the whole Prince William Sound region. The area studied (Pl. I) comprises only 65 square miles of land, yet its coast line is nearly 100 miles long. No point in the area is more than 3 miles from tidewater. Notwithstanding the short distance within which any point may be approached by boat, however, the country in this vicinity is very difficult to traverse. The land in most places rises steeply from the shores which are in many places bordered by perpendicular cliffs. Where not too steep to afford a foothold for trees, the slopes are commonly covered with a dense growth of timber up to elevations of 1,800 to 2,000 feet. Practically all travel is by boat, and few trails have been cut. There are some less rugged areas, such as those on both sides 'of the mouths of Landlocked and Galena bays, bordering Tatitlek Narrows and at the head of Galena Bay. In some parts of these lowlands the trees grow in scattered groves, with marshy meadows between, and in these places travel is less difficult.

In his discussion of the topography of the Prince William Sound region Grant ${ }^{2}$ groups certain of the lowlands as belonging to a partial peneplain developed before the last great ice advance. These lowlands include some islands near Rocky Point, the islands north and west of Bligh Island, the lowland about the village of Tatitlek, the low valley between. Boulder and Galena bays (PI. IV) and especially

1 Grant, U. S., and Higgins, D. F., Reconnaissance of the geology and mineral resources of Prince William Sound, Alaska: U. S. Geol. Survey Bull. 443, p. 18, 1910.

2 Idem, pp. 16-17. 
the point separating Landlocked and Fidalgo bays. Grant terms them "parts of an erosional surface which was developed not far above the present sea level." He states further that the upturned strata are beveled across by the plain, and the surface of the rocks is in places striated and covered with till. To use his own words: ${ }^{1}$

The plain; then, is clearly earlier than the last glaciation of the district and is thought to be a partial peneplain which has later been smoothed over by glacial ice. Some parts of the plain, especially the islands and forelands, may have been cut by wave erosion, but this would not be the case for the valleys and some protected points.

To the writers it is not clear why the lowland areas that lie only a short distance above sea level should be interpreted as parts of a peneplain. It is a fact now generally accepted among geologists that the present topography of this coastal region is due largely to the erosive effect of glacial ice. This ice erosion was active on all rock surfaces between the surface of the glacier and its bottom. The mountain slopes were scoured and shaped from an elevation of nearly 3,000 feet on Ellamar Mountain to the bottom of Valdez Arm off Rocky Point, more than 1,200 feet below sea level. It is believed that in places the glacier deepened its channel many hundreds of feet below the level of the preglacial surface. Wide areas of the bottom of the sound are level, as compared with the near-by land surfaces, and the bed of the great glacier, at the time the ice filled Prince William Sound, was comparatively smooth, although the glacier was eroding and beveling the upturned edges of the rock strata. The amount of glacial deepening by different branches of the glacier differed within rather wide limits. Some portions of the ice bed were. reduced far below the present sea level, other portions were ground down a little below sea level, and still other portions projected slightly above sea level when the glacier retreated and the sea filled the basins which had been excavated. The areas referred to by.Grant as parts of a preglacial peneplain seem to be more easily explained by assuming that they were merely portions of the glacial bed which were cut down by the ice almost to sea level, rather than by postulating another cycle of erosion in preglacial time.

The irregular and deeply indented shore line, with its projecting peninsulas and deep bays, gives protected waters and numerous harbors for small craft, and the deeper channels will admit ocean steamers.

\section{INFLUENCE OF ROCK STRUCTURE ON TOPOGRAPHY.}

The topography in this district has in some places been strongly influenced by the structure and character of the bedrock, though this influence has in other places been of minor importance. In general the greenstone has been the most resistant rock, the high 
points at Copper and Ellamar mountains being composed of it. On the other hand, the slates have suffered most from erosion, especially where the proportion of interbedded graywacke is small. Tatitlek Narrows has in large part been eroded from a band of black slates and follows the direction of their strike and schistosity. The shore line between Graveyard Point and Fish Bay also lies parallel to the strike of the slate and graywacke beds there. The head of Galena Bay and Cloudman and Busby bays on Bligh Island lie along the strike of slate and graywacke beds, but Landlocked and Boulder bays and the lower end of Galena Bay cut directly across the strike of the rocks. The northeastern part of Bligh Island lies comparatively low, yet it is composed of greenstone that in general has strongly resisted erosion. In these places other factors were more effective than the structure and character of the rocks in determining the direction of erosion lines.

\section{STREAMS.}

As a result of the deep indentation of the coast and the high relief of the land in this district, the stream gradients are everywhere steep, and the valleys are short, most of them being of the simplest type and having few tributaries. Here and there a group of moderate-sized streams with distinct valleys have joined to form a large stream, but most of the drainage has found short, direct courses to the sea. The valleys are notably lacking in stream-developed features. The large, distinct valleys owe their present-forms almost entirely to modeling by glacial ice, the evidences of stream erosion and deposition being meager. A few of the present streams have cut canyons in the bedrock, but these are small as compared with the size of the valleys in which they lie.

The largest streams in the district are the two that enter the head of Galena Bay. One of these, Duck River, empties into the lagoon at the northeast end of the bay. Most of its basin lies outside of the area studied, but it is said to drain a valley several miles long that contains a large lake fed by an active glacier. A second large stream, known as Bottle Creek, comes into the bay from the southeast. Within this area it drains a basin on the north side of Copper Mountain, which comprises about 9 square miles, and contains two rather large lakes. During the summer the flow of this creek varies greatly in volume, for the slopes of the valley walls are steep and the run-off is rapid after each rain; but it is said to maintain a fairly large flow, and a dam and hydroelectric plant were erected on it to supply power for mining in the upper part of the basin. At the time of the writers' visit the plant was not in operation.

Two other streams of considerable volume enter Galena Bay. One, which enters from the south, drains the low valley-like pass $86673^{\circ}-$ Bull. $605-15-2$ 
between Boulder and Galena bays, and the other, which enters from the north and is called Indian Creek, drains a basin lying south of the divide between Jack and Galena bays.

Two creeks of moderate size enter the head of Landlocked Bay. Lagoon Creek, the larger of these, heads to the northeast, toward the east side of Mount Denson, and in at least two places near its lower end has cut short, sharp canyons into the slates and graywackes over which it flows. In the upper canyon there is a waterfall in a narrow cleft in the rock. The stream heads outside the mapped area, and the exact location of its headwaters is not known. Reynolds Creek, the second largest tributary of Landlocked Bay, enters the bay from the northwest and drains a small area northeast of Copper Mountain. It has a canyon near its mouth. A water right has been staked on it for the purpose of developing power for the mine at Landlock.

In addition to the streams already mentioned a large number of smaller streams reach the coast, some of them permanent, though many flow intermittently. Some of these streams occupy well-defined though short valleys; others flow in shallow notches down the steep mountain sides or emerge at the sea from indefinite channels on the borders of the swampy lowlands. During a heavy rainstorm in Landlocked Bay 32 streams could be seen on the south side of Copper Mountain, where ordinarily only two or three are visible.

\section{TRANSPORTATION.}

The Ellamar district is favored with unusually good transportation facilities as compared with most parts of Alaska. As it lies on deep water it can be reached directly by ocean vessels, and it is on the regular route of the two steamship lines that ply between Seattle and ports on the Gulf of Alaska. During the summer about one boat a week, on the average, brings passengers, mail, and freight from Seattle to Ellamar, which is a regular port of call. Occasionally the boats stop both on their way west and on their return trip, but more often only once on each round trip. The channel leading to the Ellamar pier is narrow and somewhat difficult to navigate, so that passengers, mail, and light freight are usually discharged by small boat, the steamship remaining in deep water out in Tatitlek Narrows. In winter the steamships run somewhat less frequently, but even then a satisfactory service is maintained. In addition to the passenger boats several boats that carry freight exclusively are kept in service, their schedules depending to some extent on the quantity of ore available for shipment. - These boats load ore at the piers at Ellamar and Landlock. The regular fare for passengers from Seattle to Prince William Sound ports is $\$ 45$. Freight rates depend 
on the class and the amount of freight. Contracts by large shippers of ore from the mines to the smelter at Tacoma have been made at rates as low as $\$ 3$ a ton.

Since conditions for travel by boat are so favorable in this district, whereas travel on land is difficult on account of the steep slopes and heavy vegetation, very little effort has been made to improve trails or roads between the mining camps. All the large mines are near the shore and roads to them are unnecessary. Nearly every prospect has some sort of a trail leading to the nearest point on the beach. A good road about 4 miles long has been built from the head of Galena Bay to some prospects on the north side of Copper Mountain, and another road runs from the head of Landlocked Bay for about a mile to the northwest. With these exceptions nothing has been done to facilitate travel by land. Practically all communication between the mining camps is by water.

\section{Climate.}

The climate of this district is not so mild as that of southeastern Alaska nor is it subject to the great ranges of temperature of interior Alaska. Owing to the modifying effects of the Japan current, the winter temperature seldom falls below zero, and the summers are mild. In the Prince William Sound region the weather at points only a few miles apart may differ greatly, depending on their situation with relation to the mountains and valleys of the mainland, their exposure to the winds from different directions, and their nearness to the coast. For these reasons a study of the weather records taken at one place may fail to give an adequate idea of the conditions at another place near by. In the district under discussion no weather records are available, the nearest points for which a series of observations could be obtained being at Orca, Cordova, and Fort Liscum. Orca and Cordova lie about 40 miles southeast of Ellamar, but it is believed that the climate at those three places is much the same and that the temperature and precipitation at Orca and Cordova, given in the table below, represent rather closely those at Ellamar. Orca and Cordova are only 3 miles apart, and the table for Orca, covering the period between June, 1899, and March, 1908, is supplemented by the table for Cordova, extending through December, 1912. 
Monthly temperature and precipitation at Orca from June, 1899, to March 1, 1908.

\begin{tabular}{|c|c|c|c|c|c|c|}
\hline \multirow{3}{*}{ - } & \multicolumn{5}{|c|}{ Temperature ( $\left.{ }^{\circ} \mathrm{F}.\right)$. } & \multirow{3}{*}{$\begin{array}{l}\text { Pre- } \\
\text { cipita- } \\
\text { tion } \\
\text { (inches). }\end{array}$} \\
\hline & \multicolumn{2}{|c|}{$\begin{array}{l}\text { Extremes for } \\
\text { term of record. }\end{array}$} & \multicolumn{3}{|c|}{ Average by months. } & \\
\hline & $\begin{array}{l}\text { Maxi- } \\
\text { mum. }\end{array}$ & $\begin{array}{l}\text { Mini- } \\
\text { mum. }\end{array}$ & $\begin{array}{l}\text { Maxi- } \\
\text { mum. }\end{array}$ & $\begin{array}{l}\text { Mini- } \\
\text { mum. }\end{array}$ & Mean. & \\
\hline 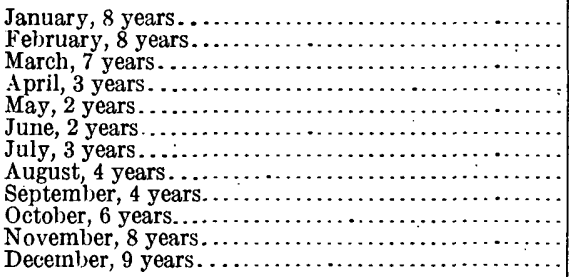 & $\begin{array}{l}45 \\
47 \\
61 \\
70 \\
72 \\
80 \\
86 \\
80 \\
84 \\
64 \\
50 \\
49\end{array}$ & $\begin{array}{r}2 \\
5 \\
2 \\
22 \\
28 \\
35 \\
33 \\
40 \\
31 \\
26 \\
11 \\
7\end{array}$ & $\begin{array}{l}40.1 \\
42.1 \\
51.7 \\
64.0 \\
68.0 \\
78.5 \\
83.0 \\
76.2 \\
74.7 \\
56.8 \\
46.6 \\
45.8\end{array}$ & $\begin{array}{l}10.3 \\
14.5 \\
11.3 \\
25.6 \\
29.0 \\
36.0 \\
40.7 \\
40.7 \\
32.6 \\
28.5 \\
18.8 \\
12.7\end{array}$ & $\begin{array}{l}27.8 \\
29.2 \\
31.2 \\
39.2 \\
44.8 \\
52.2 \\
58.5 \\
55.9 \\
49.6 \\
40.6 \\
33.0 \\
29.0\end{array}$ & $\begin{array}{r}11.30 \\
8.77 \\
7.94 \\
11.64 \\
12.09 \\
5.55 \\
4.37 \\
15.50 \\
16.35 \\
22.26 \\
13.29 \\
13.66\end{array}$ \\
\hline 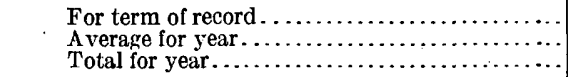 & $\begin{array}{l}\quad 86 \\
\ldots \ldots \\
\ldots \ldots\end{array}$ & $\begin{array}{l}2 \\
\cdots\end{array}$ & & & 40.9 & r \\
\hline
\end{tabular}

Monthly temperature and precipitation at Cordova from May, 1909, to December, 1912.

\begin{tabular}{|c|c|c|c|c|c|c|c|c|c|c|c|c|}
\hline \multirow{3}{*}{. } & \multicolumn{4}{|c|}{ January. } & \multicolumn{4}{|c|}{ February. } & \multicolumn{4}{|c|}{ March. } \\
\hline & \multicolumn{3}{|c|}{$\begin{array}{c}\text { Temperature } \\
\left({ }^{\delta} \text { F.). }\right.\end{array}$} & \multirow{2}{*}{$\begin{array}{c}\text { Pre- } \\
\text { cipita- } \\
\text { tion } \\
\text { (inches) }\end{array}$} & \multicolumn{3}{|c|}{$\begin{array}{l}\text { Temperature } \\
\left({ }^{6} \mathbf{F} .\right) \text {. }\end{array}$} & \multirow{2}{*}{$\begin{array}{c}\text { Pre- } \\
\text { cipita- } \\
\text { tion } \\
\text { (inches) }\end{array}$} & \multicolumn{3}{|c|}{$\begin{array}{c}\text { Temperature } \\
\left({ }^{6} \mathrm{~F} .\right) \text {. }\end{array}$} & \multirow{2}{*}{$\begin{array}{c}\text { Pre- } \\
\text { cipita- } \\
\text { tion. } \\
\text { (inches). }\end{array}$} \\
\hline & $\begin{array}{l}\text { Maxi- } \\
\text { mum. }\end{array}$ & Mini- & Mean. & & Maxi- & Mini- & Mean. & & $\begin{array}{l}\text { Maxi- } \\
\text { mum. }\end{array}$ & Mum. & Mean. & \\
\hline \multirow{5}{*}{$\begin{array}{r}1909 \ldots \ldots \ldots \\
1910 \ldots \ldots \\
1911 \ldots \ldots \ldots \\
1912 \ldots \ldots \\
\quad \text { Average .... } \\
\end{array}$} & $\begin{array}{l}40 \\
45 \\
47\end{array}$ & $\begin{array}{r}9 \\
5 \\
13\end{array}$ & $\begin{array}{l}25.5 \\
30.4 \\
33.1\end{array}$ & $\begin{array}{r}8.89 \\
4.91 \\
10.00\end{array}$ & $\begin{array}{l}40 \\
42 \\
51\end{array}$ & $\begin{array}{r}4 \\
11 \\
25\end{array}$ & $\begin{array}{l}27.8 \\
30.0 \\
36.1\end{array}$ & $\begin{array}{r}7.50 \\
13.69 \\
12.21\end{array}$ & $\begin{array}{l}45 \\
46 \\
49\end{array}$ & $\begin{array}{r}8 \\
1 \\
23\end{array}$ & $\begin{array}{l}32.4 \\
29.6 \\
35.7\end{array}$ & $\begin{array}{r}16.18 \\
8.07 \\
17.50\end{array}$ \\
\hline & 43 & 9 & 29.6 & 7.93 & 44.2 & 13.3 & 31.3 & 11.1 & 46.6 & 18.6 & 32.5 & 13.91 \\
\hline & \multicolumn{4}{|c|}{ A pril. } & \multicolumn{4}{|c|}{ May. } & \multicolumn{4}{|c|}{ June. } \\
\hline & \multicolumn{3}{|c|}{$\begin{array}{c}\text { Temperature } \\
\left({ }^{\circ} \mathrm{F} .\right) .\end{array}$} & \multirow{2}{*}{$\begin{array}{c}\text { Pre- } \\
\text { cipita- } \\
\text { tion } \\
\text { (inches). }\end{array}$} & \multicolumn{3}{|c|}{$\begin{array}{l}\text { Temperature } \\
\left({ }^{8} \mathrm{~F} .\right) \text {. }\end{array}$} & \multirow{2}{*}{$\begin{array}{c}\text { Pre- } \\
\text { cipita- } \\
\text { tion } \\
\text { (inches). }\end{array}$} & \multicolumn{3}{|c|}{$\begin{array}{c}\text { Temperature } \\
\left({ }^{\circ} \mathrm{F} .\right) \text {. }\end{array}$} & \multirow{2}{*}{$\begin{array}{c}\text { Pre- } \\
\text { cipita- } \\
\text { tion } \\
\text { (inches). }\end{array}$} \\
\hline & $\begin{array}{l}\text { Maxi- } \\
\text { mum. }\end{array}$ & Mini- & Mean. & & Maxi - & Mini- & Mean. & & Maxi - & Mini- & Mean. & \\
\hline $\begin{array}{l}1909 . . \\
1910 . \\
1911 . \\
1912 .\end{array}$ & $\begin{array}{l}52 \\
47 \\
59\end{array}$ & $\begin{array}{l}20 \\
15 \\
27\end{array}$ & $\begin{array}{l}36.0 \\
30.8 \\
40.5\end{array}$ & $\begin{array}{r}5.34 \\
14.79 \\
4.02\end{array}$ & $\begin{array}{l}64 \\
66 \\
57 \\
70\end{array}$ & $\begin{array}{l}35 \\
31 \\
28 \\
33\end{array}$ & $\begin{array}{l}45.8 \\
46.2 \\
41.4 \\
45.2\end{array}$ & $\begin{array}{r}6.09 \\
6.21 \\
8.42 \\
20.29\end{array}$ & $\begin{array}{l}74 \\
68 \\
73 \\
68\end{array}$ & $\begin{array}{l}39 \\
37 \\
34 \\
37\end{array}$ & $\begin{array}{l}50.4 \\
48.6 \\
49.0 \\
50.0\end{array}$ & $\begin{array}{r}14.63 \\
5.82 \\
8.74 \\
5.66\end{array}$ \\
\hline Average..... & 52.6 & 20.6 & 35.7 & 8.05 & 64.2 & 31.7 & 44.6 & 10.25 & 70.7 & 36.7 & 49.5 & 8.71 \\
\hline
\end{tabular}


Monthly temperature and precipitation at Cordova from May, 1909, to December, 1912-Con.

\begin{tabular}{|c|c|c|c|c|c|c|c|c|c|c|c|c|}
\hline \multirow{3}{*}{ v } & \multicolumn{4}{|c|}{ July. } & \multicolumn{4}{|c|}{ August. } & \multicolumn{4}{|c|}{ September. } \\
\hline & \multicolumn{3}{|c|}{ Temperature } & \multirow{2}{*}{$\begin{array}{c}\text { Pre- } \\
\text { cipita- } \\
\text { tion } \\
\text { (inches). }\end{array}$} & \multicolumn{3}{|c|}{$\begin{array}{c}\text { Temperature } \\
(\mathrm{F} .) \text {. }\end{array}$} & \multirow{2}{*}{$\begin{array}{c}\text { Pre- } \\
\text { cipita- } \\
\text { tion } \\
\text { (inches). }\end{array}$} & \multicolumn{3}{|c|}{ Temperature } & \multirow{2}{*}{$\begin{array}{c}\text { Pre- } \\
\text { cipita- } \\
\text { tion } \\
\text { (inches) }\end{array}$} \\
\hline & $\begin{array}{l}\text { Maxi- } \\
\text { mum. }\end{array}$ & Mini- & Mean. & & $\begin{array}{l}\text { Maxi- } \\
\text { mum. }\end{array}$ & Mini- & Mean. & & $\begin{array}{l}\text { Maxi- } \\
\text { mum. }\end{array}$ & Mini- & Mean. & \\
\hline $\begin{array}{l}1909 \ldots \\
1910 \ldots \\
1911 \ldots \\
1912 \ldots\end{array}$ & $\begin{array}{l}71 \\
71 \\
78 \\
77\end{array}$ & $\begin{array}{l}47 \\
42 \\
45 \\
45\end{array}$ & $\begin{array}{l}56.6 \\
53.7 \\
55.2 \\
49.1\end{array}$ & $\begin{array}{l}4.95 \\
7.51 \\
4.37 \\
4.99\end{array}$ & $\begin{array}{l}67 \\
73 \\
\ldots \\
65\end{array}$ & \begin{tabular}{r}
42 \\
45 \\
\hdashline$\%$ \\
40
\end{tabular} & $\begin{array}{l}54.8 \\
56.6 \\
50.2\end{array}$ & $\begin{array}{r}8.86 \\
6.39 \\
23.16\end{array}$ & $\begin{array}{l}61 \\
72 \\
65 \\
64\end{array}$ & $\begin{array}{l}32 \\
37 \\
39 \\
41\end{array}$ & $\begin{array}{l}47.0 \\
51.4 \\
55.1 \\
48.0\end{array}$ & $\begin{array}{l}19.17 \\
12.61 \\
11.27 \\
49.63\end{array}$ \\
\hline A verage..... & 74.2 & 44.7 & 53.6 & 5.45 & 68.3 & 42.3 & 53.8 & 12.80 & 65.5 & 37.2 & 50.3 & 23.17 \\
\hline - & \multicolumn{4}{|c|}{ October. } & \multicolumn{4}{|c|}{ November. } & \multicolumn{4}{|c|}{ December. } \\
\hline & \multicolumn{3}{|c|}{$\begin{array}{c}\text { Temperature } \\
\left.\text { ( }{ }^{\delta} \mathrm{F} .\right) .\end{array}$} & \multirow{2}{*}{$\begin{array}{c}\text { Pre- } \\
\text { cipita- } \\
\text { tion } \\
\text { (inches). }\end{array}$} & \multicolumn{3}{|c|}{$\begin{array}{l}\text { Temperature } \\
\left({ }^{\circ} \mathrm{F} .\right) .\end{array}$} & \multirow{2}{*}{$\begin{array}{c}\text { Pre- } \\
\text { cipita- } \\
\text { tion } \\
\text { (inches). }\end{array}$} & \multicolumn{3}{|c|}{$\begin{array}{l}\text { Temperature } \\
\left({ }^{\circ} \mathrm{F} .\right) \text {. }\end{array}$} & \multirow{2}{*}{$\begin{array}{c}\text { Pre- } \\
\text { cipita- } \\
\text { tion } \\
\text { (inches). }\end{array}$} \\
\hline & $\begin{array}{l}\text { Maxi- } \\
\text { mum. }\end{array}$ & Mumi- & Mean. & & $\begin{array}{l}\text { Maxi- } \\
\text { mum. }\end{array}$ & Mum. & Mean. & & $\begin{array}{l}\text { Maxi- } \\
\text { mum. }\end{array}$ & Mini- & Mean. & \\
\hline $\begin{array}{l}1909 . . \\
1910 . . \\
1911 . \\
1912 .\end{array}$ & $\begin{array}{l}49 \\
53 \\
53 \\
53\end{array}$ & $\begin{array}{l}28 \\
30 \\
32 \\
29\end{array}$ & $\begin{array}{l}39.1 \\
41.3 \\
44.0 \\
40.1\end{array}$ & $\begin{array}{r}9.04 \\
19.70 \\
15.90 \\
24.88\end{array}$ & $\begin{array}{l}42 \\
46 \\
49 \\
59\end{array}$ & $\begin{array}{l}12 \\
20 \\
21 \\
24\end{array}$ & $\begin{array}{l}26.8 \\
35.0 \\
34.0 \\
39.9\end{array}$ & $\begin{array}{l}1.69 \\
6.37 \\
9.80 \\
5.83\end{array}$ & $\begin{array}{l}42 \\
43 \\
43 \\
47\end{array}$ & $\begin{array}{r}11 \\
5 \\
15 \\
9\end{array}$ & \begin{tabular}{l|}
29.7 \\
30.3 \\
30.3 \\
21.7
\end{tabular} & $\begin{array}{r}19.22 \\
9.33 \\
21.47 \\
13.17\end{array}$ \\
\hline A verage.. & 52 & 29.7 & 41.1 & 17.38 & 49.0 & 19.2 & 33.9 & 5.92 & 43.7 & 10 & 28.0 & 15.87 \\
\hline
\end{tabular}

A verage annual precipitation for period of record, 140.54 inches. Precipitation in 1912, 191.64 inches.

Fort Liscum is only 18 miles northeast of Ellamar, but it lies near the head of Port Valdez, a narrow arm of the sound extending well into the heart of the Chugach Range. The climate at Fort Liscum is that of the coastal mountains, somewhat modified by the presence of a body of salt water. The mean annual temperature is $35.3^{\circ}$, as compared with $40.3^{\circ}$ at Cordova, and the precipitation is just about half as great as at Cordova.

Monthly temperature ind precipitation at Fort Liscum from January, 1901, to December, 1912.

\begin{tabular}{|c|c|c|c|c|c|c|c|c|c|c|c|c|}
\hline \multirow[b]{3}{*}{. } & \multicolumn{4}{|c|}{ January. } & \multicolumn{4}{|c|}{ February: } & \multicolumn{4}{|c|}{ March. } \\
\hline & \multicolumn{3}{|c|}{$\begin{array}{c}\text { Temperature } \\
\left({ }^{\delta} \mathrm{F} .\right) \text {. }\end{array}$} & \multirow{2}{*}{$\begin{array}{c}\text { Pre- } \\
\text { cipita- } \\
\text { tion } \\
\text { (inches). }\end{array}$} & \multicolumn{3}{|c|}{$\begin{array}{c}\text { Temperature } \\
\left({ }^{\delta} \mathrm{F} .\right) .\end{array}$} & \multirow{2}{*}{$\begin{array}{c}\text { Pre- } \\
\text { cipita- } \\
\text { tion } \\
\text { (inches). }\end{array}$} & \multicolumn{3}{|c|}{$\begin{array}{c}\text { Temperature } \\
\left({ }^{\circ} \mathrm{F} .\right) .\end{array}$} & \multirow{2}{*}{$\begin{array}{c}\text { Pre- } \\
\text { cipjta- } \\
\text { tion } \\
\text { (inches). }\end{array}$} \\
\hline & $\begin{array}{l}\text { Maxi- } \\
\text { mum. }\end{array}$ & Mini- & Mean. & & $\begin{array}{l}\text { Maxi- } \\
\text { mum. }\end{array}$ & $\begin{array}{l}\text { Mini- } \\
\text { mum. }\end{array}$ & Mean. & & $\begin{array}{l}\text { Maxi- } \\
\text { mum }\end{array}$ & $\begin{array}{l}\text { Mini- } \\
\text { mum }\end{array}$ & Mean. & \\
\hline 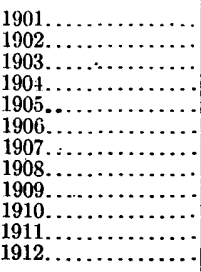 & $\begin{array}{l}41 \\
45 \\
36 \\
42 \\
43 \\
36 \\
44 \\
37 \\
39 \\
34 \\
37 \\
38\end{array}$ & $\begin{array}{r}-1 \\
-14 \\
-10 \\
-7 \\
5 \\
-8 \\
2 \\
-5 \\
-12 \\
-3 \\
2 \\
6\end{array}$ & $\begin{array}{l}23.8 \\
22.0 \\
16.2 \\
22.6 \\
23.4 \\
12.5 \\
20.8 \\
23.5 \\
10.8 \\
18.6 \\
19.9 \\
25.2\end{array}$ & $\begin{array}{r}9.40 \\
9.94 \\
10.42 \\
6.80 \\
3.63 \\
12.53 \\
1.75 \\
16.58 \\
2.29 \\
8.79 \\
1.98 \\
2.76\end{array}$ & $\begin{array}{l}41 \\
42 \\
39 \\
42 \\
40 \\
38 \\
36 \\
40 \\
40 \\
39 \\
45 \\
40\end{array}$ & $\begin{array}{r}-12 \\
6 \\
-10 \\
2 \\
8 \\
7 \\
-9 \\
5 \\
-\quad 2 \\
0 \\
0 \\
19\end{array}$ & $\begin{array}{l}15.6 \\
24.4 \\
19.8 \\
21.2 \\
24.2 \\
24.0 \\
15.8 \\
26.6 \\
16.1 \\
18.4 \\
19.9 \\
30.5\end{array}$ & $\begin{array}{r}0.80 \\
1.28 \\
13.60 \\
.52 \\
5.73 \\
1.83 \\
10.14 \\
7.22 \\
2.57 \\
6.45 \\
5.11 \\
3.03\end{array}$ & $\begin{array}{l}52 \\
44 \\
39 \\
49 \\
54 \\
44 \\
38 \\
39 \\
41 \\
45 \\
42 \\
44\end{array}$ & $\begin{array}{r}10 \\
-8 \\
2 \\
5 \\
16 \\
18 \\
3 \\
2 \\
8 \\
0 \\
-5 \\
13\end{array}$ & $\begin{array}{l}30.8 \\
20.4 \\
21.8 \\
24.8 \\
32.8 \\
31.2 \\
20.6 \\
26.7 \\
26.8 \\
25.0 \\
20.4 \\
30.4\end{array}$ & $\begin{array}{l}6.38 \\
4.70 \\
4.72 \\
.10 \\
7.17 \\
7.54 \\
6.04 \\
6.58 \\
5.80 \\
9.80 \\
4.27 \\
9.68\end{array}$ \\
\hline Average..... & 39.3 & -3.7 & 19.9 & 7.24 & 40.1 & 1.1 & 21.3 & 4.85 & 44.2 & 5.3 & 25.9 & 6.06 \\
\hline
\end{tabular}


Morthly temperature and precipitation at Fort Liscum from January, 1901, to December, 1912-Continued.

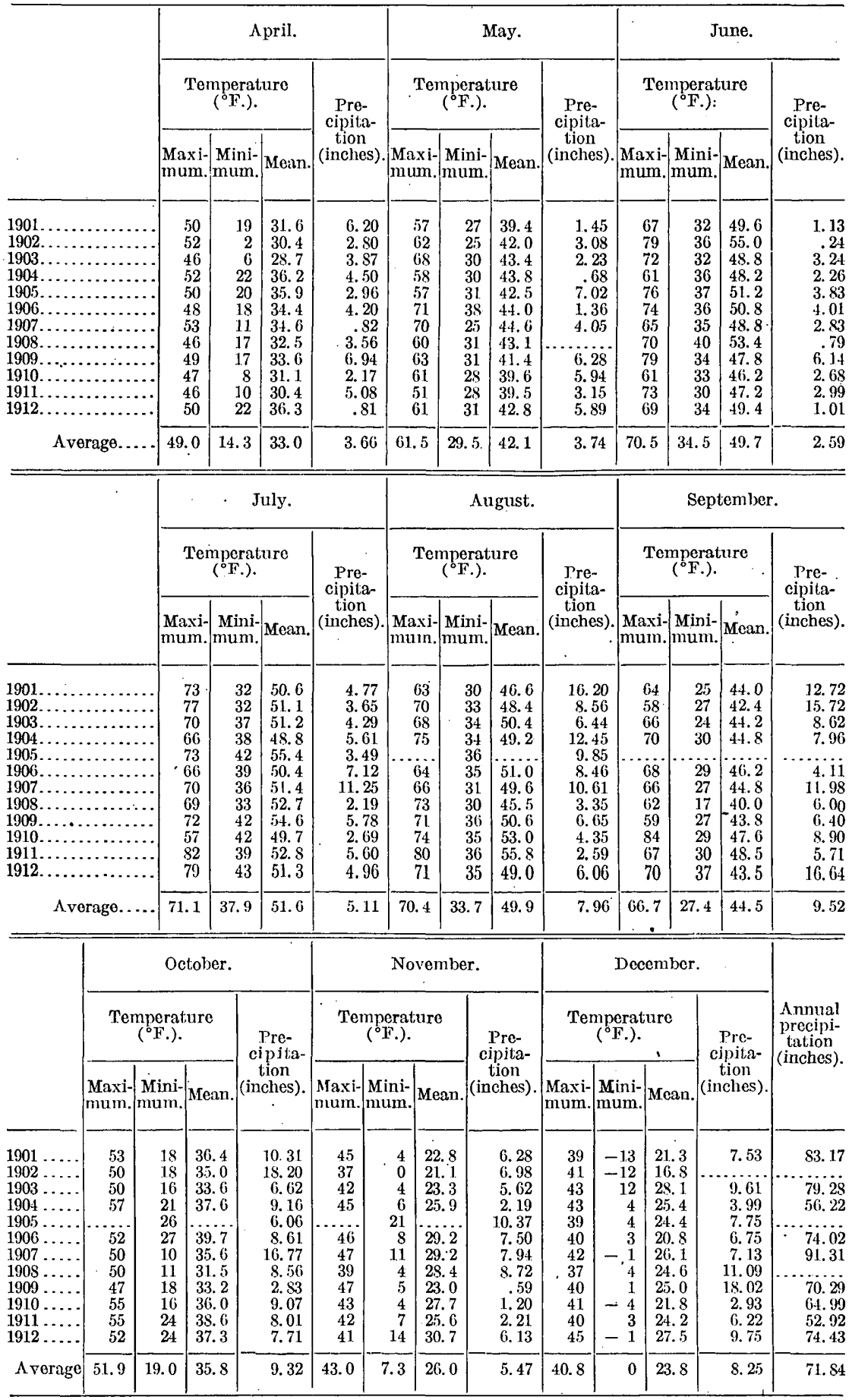


The weather near Ellamar during 1912 is believed to have been much the same as that at Cordova. The precipitation was unusually heavy for the whole year, and during the period spent in field work, including part of August, all of September, and part of October, the rainfall was enormous. During these three months the records at Cordova show a rainfall of over 97 inches, of which nearly 50 inches fell in September. At Ellamar, during the same months, the rainfall was probably equally heavy, and late in September, during one storm lasting three days, it is estimated that 24 inches of water fell at the head of Galena Bay. The precipitation in 1912 was about 50 inches greater than the average.

\section{VEGETATION.}

As a result of the heavy rainfall and mild climate in this region the vegetation is luxuriant. Timber grows to elevations of 1,800 to 2,000 feet, except on the steepest mountain slopes and in some of the marshes. (See fig. 2, p. 24.) The Ellamar district lies within the limits of the Chugach National Forest and the cutting of timber is subject to the regulations of the Forest Service. The largest and most important trees are spruce and hemlock, there being at least two varieties of each. Trees 4 feet or more in diameter at the base are common and grow.tall and free from knots, making good clear lumber. Hemlock is more abundant than spruce, but the spruce is more desirable, as it makes better lumber than the hemlock and is also better for firewood. In the vicinity of the larger settlements most of the spruce near the beach has been cut. The natives cut most of the firewood and prefer trees which may be made to fall close to the water, even though it is necessary to tow them a long distance to the points at which they are to be used. The total amount of timber which has been cut is, however, insignificant as compared with that which remains.

Below timber line the ground is generally covered with sphagnum moss, which acts as a sponge and retains large quantities of water, so that it is nearly everywhere wet underfoot. The untimbered marshy meadows are full of small ponds, and the ground is saturated with water. In the forests alder, willow, and other bushy plants grow thickly between the trees and the spiny devil's club, familiar throughout the rainy belt of the coast country, is present in abundance. The thick brush, fallen trees, and the prevailing steep slopes of the mountains make travel through most of the timbered areas slow and difficult, and the mossy covering of the surface renders it difficult for the prospector or geologist to trace the contacts of the different rock formations, or even to determine the surface formations over considerable areas. Above an elevation of about 2,000 feet, however, 
there is little timber or other vegetation, and the bare rock is commonly exposed.

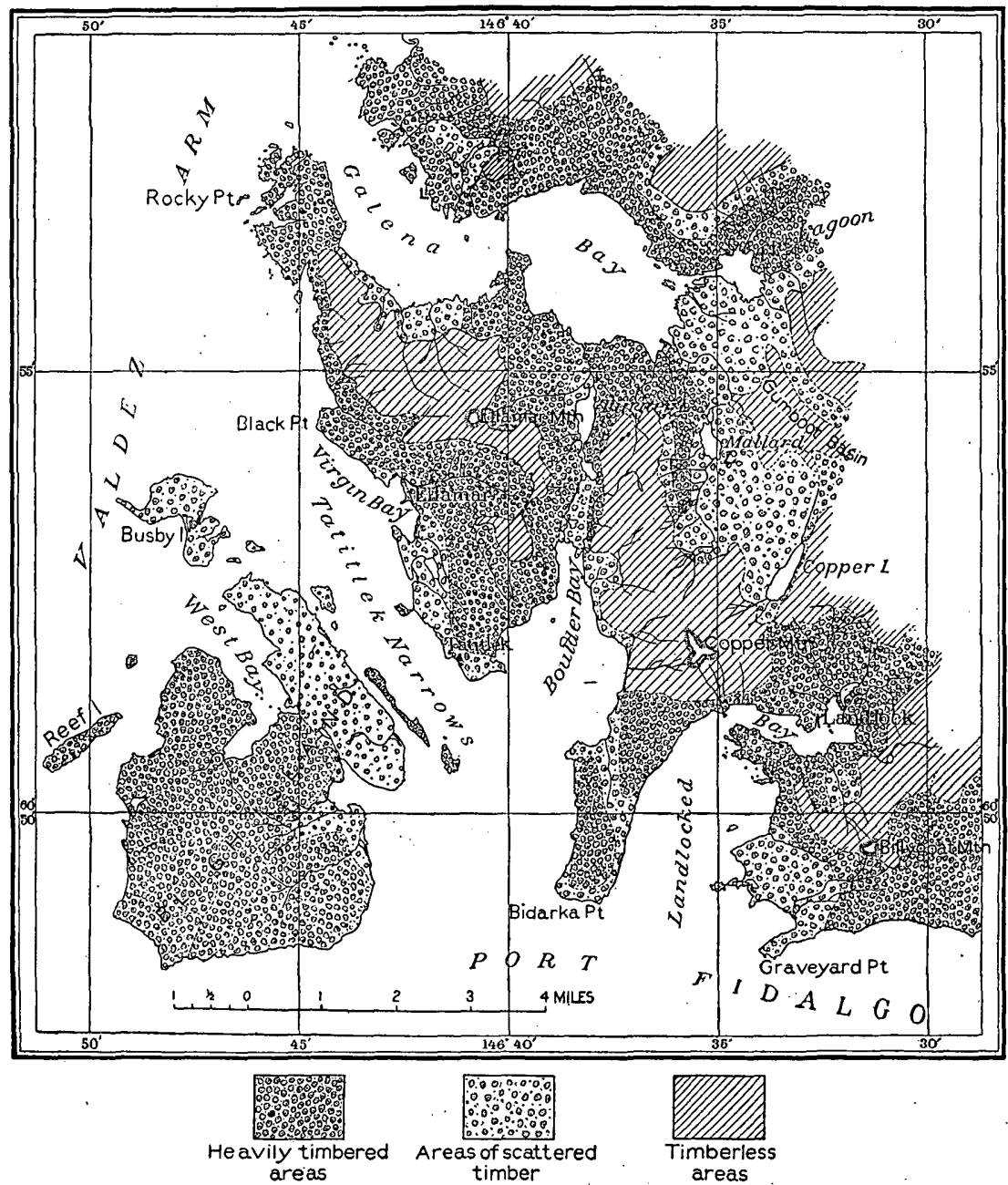

FIGURE 2.-Sketch map showing distribution of timber in Ellamar district.

A number of edible berries grow in this region, including two varieties of blueberry, salmon berries, a so-called black currant, some raspberries, and a few small cranberries.

\section{POPULATION.}

The district discussed in this report has a total population of about 300 , of which about 100 are whites and the remainder natives, many of whom, however, are of mixed white and native blood. The largest village is the native settlement of the Tatitlek, whose population is about 150. Ellamar village is next in size. More than half of its population of about 100 are natives or people of mixed race. 
The settlement of Landlock contains about 30 whites, and about a dozen other white men are mining or prospecting on Landlocked Bay. One family lives on Boulder Bay, another on Galena Bay, and one on Bligh Island, which contains a fox ranch that has produced a large number of foxes during the last 12 years. Practically all the whites are directly or indirectly engaged in mining or prospecting, and the natives support themselves by fishing, hunting, and by cutting cordwood or doing other work for the whites.

\section{GAMEE.}

There are few large game animals in this district. Black and brown bears are seldom seen, but mountain goats are sometimes seen near Mount Denson, though they rarely come farther southwest. Spruce . grouse are abundant in the timber, and ptarmigan are often found ahove timber line. Water fowl are very abundant. Many varieties of edible salt-water ducks remain throughout the year. During the spring and fall flocks of geese and brant, and mallard, teal, bluebill, and other varieties of ducks are seen everywhere and are comparatively easy to approach. During the spring and summer salmon ascend the larger streams in thousands. Cod, halibut, red snapper, and bass are among the most valuable salt-water fish, and clams live on the beach in many places.

\section{GENERAL GEOLOGY.}

By S. R. CAPPS.

\section{DIVISIONS OF THE ROCKS.}

The rocks of the Prince William Sound area were first divided into two main groups by Schrader, ${ }^{1}$ in 1898 , and although a number of geologists have since worked in different parts of this field, Schrader's major subdivision still stands. Grant and Higgins ${ }^{2}$ later made a much more exhaustive study of the rocks of Prince William Sound, extending the known area of these two groups. In a general way they divided the younger group into two units, one dominantly igneous and the other dominantly sedimentary. The completion of a topographic map of the Ellamar district on a scale of $1: 62,500$ and the opportunity to study this area in the field in the light of the previous investigations, with the accumulated published data and unpublished notes, have made it possible to subdivide the younger of the two groups with greater accuracy than has heretofore been possible and to work out details of structure which were beyond the

\footnotetext{
1 Schrader, F. C., A reconnaissance of a part of Prince William Sound and the Copper River district, Alaska, in 1898: U.S. Geol. Survey Twentieth Ann. Rept., pt. 7, pp. 265-340, 1900.

${ }^{2}$ Grant, U. S., and Higgins, D. F., Reconnaissance of the geology and mineral resources of Prince William Sound, Alaska: U. S. Geol. Survey Bull. 443, 1910.
} 
scope of the earlier reconnaissance surveys. The accompanying geologic map (Pl. II, in pocket), though by no means final in its delineation of the geologic boundaries, is based on much more detailed information than any preceding map. Along the shore line and in places where the rocks are well exposed the mapping is believed to be accurate. In many of the areas that are covered with timber and vegetation, where exposures were unsatisfactory or lacking, the boundaries were drawn from inference and may be somewhat changed when more complete information becomes available. No determinable fossils have been found in the Ellamar district, and the names and tentative determinations of the age of the two rock groups published by Grant and Higgins have been accepted. In certain places, .too, it has been impossible to determine definitely to which of the two great groups certain rocks belong. In those places the map by Grant and Higgins has been followed unless the evidence found points strongly to a different conclusion. If evidence equally strong seemed to indicate that the rocks may be classed with either group, no change was made. As fossils were not available for locating the position of any rock formation in the geologic column, the geologic sequence has necessarily been determined solely by the structural relations of the rock units. Some uncertainties therefore exist, for the relations are in most places complicated by folding and faulting, and critical areas are commonly concealed by vegetation.

\section{GEOLOGIC HISTORY.}

The accompanying columnar section (fig. 3 ) is a graphic summary of the stratigraphy of the district. The oldest rocks in the district, as well as in the whole Prince William Sound region, have been called the Valdez group, from their typical development around Port Valdez. This group consists primarily of a great thickness of slate and graywacke beds, which in some places alternate in thin beds and in about equal amounts, but in other places one or the other phase predominates. When deposited they consisted of muds and feldspathic sands, which were subsequently consolidated into shales and feldspathic sandstones and later subjected to vigorous earth movements during which the beds were folded, faulted, and uplifted, the shales altered to slates and the sandstones to dense, hard graywackes. In places the metamorphism was even more complete, and mica was developed in the rocks, which took on a schistose character and were distorted by folding in two or more directions. The rocks of this group, after they had undergone at least a part of their metamorphism, were uplifted abore sea level and became a land mass on which the agencies of erosion were active for an unknown period of time. Rocks of this age are believed to form the greater part of the Chugach Range north and northeast of Prince William Sound and 
most of the Kenai Mountains to the west. It is known, however, that within the area of rocks on Kenai Peninsula, formerly believed to be the equivalent in age of the Valdez group, fossiliferous rocks of later age occur, and with more complete information it may be found that the extent of the Valdez rocks is less than has hitherto been thought. No conclusive evidence of the age of the Valdez group has beenfound, but for reasons which will be given later it is provisionally assigned to the Paleozoic.

After the Valdez rocks had been consolidated, somewhat deformed, and at least a part of them elevated above sea level and eroded, there was a subsidence of unknown area, and some of the Valdez rocks were again brought below the surface of the sea and received a cover of younger sediments, also composed in large part of muds and feldspathic sands. The source of the materials from which these sediments were derived is not clear, but they probably came in part

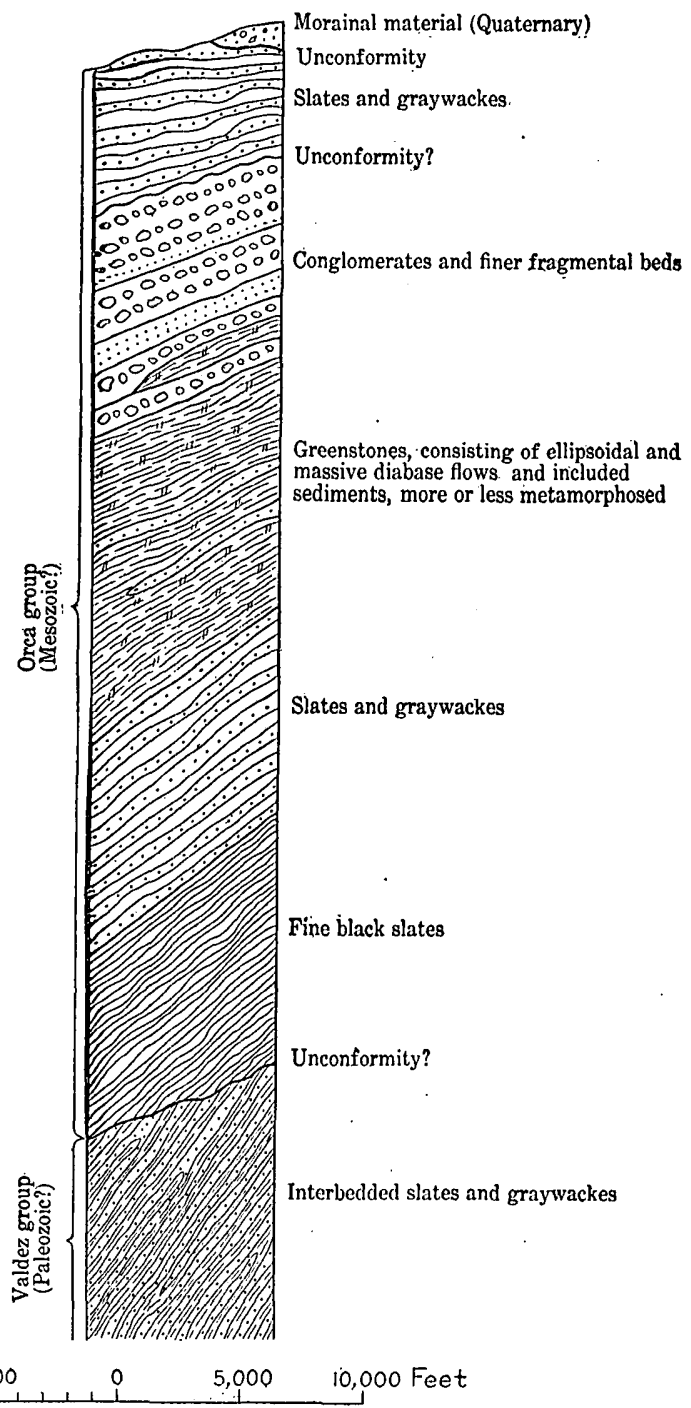

FIGURE 3.-Generalized columnar section of the rocks of Ellamar district.

from the erosion of those portions of the Valdez group which remained out of water. The sedimentation continued for a long period, and conditions differed somewhat from time to time and in different parts of the basin. In the region here studied the lowest rocks were deposited as black muds, with little sandy material. Later on feldspathic sands 
alternated with the layers of mud. After the series had reached a thickness of several thousand feet the hitherto continuous deposition was interrupted by great volcanic activity. From one or more vents, the location of which is uncertain, great quantities of basaltic lava were poured out on the ocean bottom, covering the sands and muds which had already accumulated there. The lava flows were intermittent, following one another at irregular intervals. Sometimes one lava flow was poured out immediately on the top of a previous flow without intervening sediments. After other flows a layer of sand or mud was deposited on the lava surface, to be covered by the next lava flow, the thickness of the sedimentary beds depending on the length of the interval between the volcanic outbursts. In this manner a thick series of lava beds, interstratified with sedimentary beds, was gradually built up, until portions of the basin were probably filled to sea level or nearly so. As the volcanic activity died out and the lava floods became less frequent, the sedimentary beds became proportionately thicker, until the igneous activity ceased altogether.

Perhaps as a result of the shoaling of the water by the great accumulation of sediments and lava, or from other. reasons, such as the elevations of portions of the land, coarser sediments were carried into the sea in parts of the area, and coarse sands and bowlders accumulated locally to a great thickness while at other places the sands and muds were being laid down.

The next event in the geologic history is not very clear. There may have been local folding and metamorphism before any later deposits were made. At any rate, the deposition of muds and sands continued after the lava flows had ceased and after the bowlder beds were laid down. This deposition was continued for an unknown period of time, and the beds have since been consolidated into shales, graywackes, and conglomerates, and have been gently folded and faulted. In some places a distinct slaty cleavage has been imparted to the slates. These beds are the youngest rocks exposed in the Ellamar district, though in other parts of the sound there are probably somewhat younger beds. While the sedimentary beds were being changed from muds and feldspathic sands to slates and graywackes the lava flows were altered by chemical and mechanical changes and are now commonly spoken of as greenstones, varying from recognizable lava flows to serpentines and even to talcose materials. The whole series of rocks has been subjected to folding, and great faults have broken the beds and confused their normal relations. It is known that this district has been affected by two periods of metamorphism. During the earlier period, before the Orca beds were laid down, the Valdez sediments were altered and converted into hard slates and graywackes. The second period involved both the Valdez and Orca rocks. The lava flows of the Orca group were locally altered into serpentines and 
amphibolite schists and the slates and graywackes were intricately contorted. This metamorphism was practically completed, however, before the deposition of the ore bodies, which show no evidence of severe metamorphism and which were introduced by hydrothermal agencies into shear zones that were formed at an earlier period. The rocks of the district are therefore believed to have been metamorphosed nearly to their present condition before the ore bodies were introduced. The whole assemblage of rocks from the top of the Valdez group to the latest slates and graywackes, including the lava flows and conglomerates, have been assigned to the Orca group, probably of Mesozoic age.

Several chapters, covering the long period of time between the deposition of the Orca rocks and the glacial epoch, are missing from the geologic record in Prince William Sound. During that period neighboring parts of Alaska, including Cook Inlet and the Susitna Basin, were depressed and received a great thickness of sediments, including Cretaceous, Eocene, and later Tertiary beds, which are not known to be represented about Prince William Sound, so that much of the territory around that sound probably then stood above sea level. The mountain-building processes that formed the Chugach Range have probably been more or less continuous for a very long period. The region was subjected to compression before the Orca rocks were laid down, and the earth movements have continued since, deforming the Orca beds. The growth of the mountains may have begun early in Mesozoic time and have continued intermittently ever since.

After the Orca sediments had-been consolidated and metamorphosed, in some degree at least, great intrusive masses were injected into the mountains of the Chugach Range. These masses were dioritic or granitic in texture and probably accompanied the widespread intrusion of similar rocks in many parts of Alaska and of western North America. None of these granitic bodies are known in the Ellamar district, but there are many of them around the shores of Prince William Sound. The granitic intrusions were accompanied by extensive folding and faulting and the relations between the granitic masses and the metalliferous veins in the surrounding rocks in many places seem to indicate that the copper deposits of the Ellamar district may be a result of these intrusions. The origin of the copper deposits is discussed in another part of this report.

With the beginning of the glacial epoch the mountains had reached a considerable height, perhaps not far different from their present elevation, and well-developed valleys had been eroded in them by streams. During the glacial epoch ice tongues moved down the valleys, joining at the border of the mountains to form a great ice sheet in the basin now occupied by Prince William Sound. On the 
retreat of the ice the sea gradually filled those parts of the glacier basin which lay below sea level. Many glaciers, especially those in the northwestern part of the sound, are still active and discharge into the sea. Others have retreated some distance above sea level but occupy the upper ends of the valleys. Since the glaciers have retreated, erosion by streams has been resumed on the bared land areas, attacking both the deposits left by the ice and the rock surfaces. In the higher mountains glacial erosion is still active.

\section{ROCK FORMATIONS.}

VALDEZ GROUP.

\section{DISTRIBUTION.}

The Valdez group was named and described in 1898 by Schrader, ${ }^{1}$ who studied the exposures around Port Valdez and traced the rocks of this group eastward to Copper River. They have later been studied by a number of geologists, and the best description of their character and areal extent is that by Grant and Higgins. ${ }^{2}$ The rocks of this group have a wide areal extent. Their eastern limit, so far as now known, ${ }^{3}$ is near the head of Bremner River, a tributary of Copper River from the east. West of Copper River the Valdez rocks, together with those of the Orca group, comprise the greater part of the mass of the Chugach Mountains, though some older beds occur on the north flank of the range. In the area around Turnagain Arm rocks that appear to be the westward extension of the Valdez group have been described by Mendenhall ${ }^{4}$ as the Sunrise group, and the areal distribution of this group has been shown by the work of Moffit, ${ }^{5}$ Mendenhall, Paige and Knopf, ${ }^{6}$ and Martin ${ }^{7}$ to include most of the mountainous portion of Kenai Peninsula. The rocks of the Valdez group, though in general somewhat more metamorphosed than those of the Sunrise group, are lithologically similar to them and have been traced along the shores of Prince William Sound and across to the type locality for the Sunrise group, on Turnagain Arm, without any apparent break. It therefore seems 'certain that, in part at least, the Valdez and Sunrise groups are the same, though it

\footnotetext{
1 Schrader, F. C., A reconnaissance of a part of Prince William Sound and the Copper River district, Alaska, in 1898: U. S. Geol. Survey Twentieth Ann. Rept., pt. 7, pp. 408-410, 1900.

2 Grant, U. S., and Higgins, D. F., Reconnaissance of the geology and mineral resources of Prince William Sound, Alaska: U. S. Geol. Survey Bull. 443, pp. 22-24, 1910.

3 Moflit, F. H., Geology of the Hanagita-Bremner region, Alaska: U. S. Geol. Survey Bull. 576, pp. 22-23, 1914.

${ }^{4}$ Mendenhall, W. C., A reconnaissance from Resurrection Bay to the Tanana River, Alaska, in 1s98: U. S. Geol. Survey Twentieth Ann. Rept., pt. 7, pp. 305-307, 1900.

${ }^{6}$ Moffit, F. H., Gold fields of the Turnagain Arm region: U. S. Geol. Survey Bull. 277, pp. 17-19, 1906.

6 Paige, Sidney, and Knopf, Adolph, Geologic reconnaissance in the Matanuska and Talkeetna basins, Alaska: U. S. Geol. Survey Bull. 327, pp. 12-16, 1907.

7 Martin, G. C., General features of Kenai Peninsula: U. S. Geol. Survey Bull. 587, pp. 33-34, 1915.
} 
is now known that certain beds occur within the area hitherto mapped as Sunrise which from their fossils are believed to be more closely related to the younger Orca group. In 1913 B. L. Johnson collected at several localities in the Port Wells district fossils that are possibly of Mesozoic age, though the rocks in which they were found had previously been mapped with the Valdez group. The Sunrise group therefore must consist of undifferentiated rocks, probably equivalent in age to both the Valdez and Orca groups, though Grant and Higgins mapped it as the equivalent of the Valdez.

To summarize, the Valdez rocks extend westward from the head of Bremner River and west of Copper River form the greater part of the Chugach Range. They are bordered on the south by the younger Orca group and on the north, in part at least, by older Paleozoic rocks. Between Port Wells and Matanuska River and over most of Kenai Peninsula some of the rocks of the Sunrise group are correlated with the Valdez group.

In the Ellamar district the southern edge of the Valdez group appears, and southeast of these rocks lies the Orca group (Pl. II, in pocket). The contact between the two groups cuts the shore about a mile northeast of the mouth of Galena Bay and runs southwestward to the edge of the area mapped, crossing the heads of Galena and Landlocked bays. The position of the contact in the region east of the area shown on Plate II is not known. The Valdez rocks seem to be continuous northeast of this contact through the higher parts of the Chugach Range, though little detailed work has been done in that area.

\section{CHARACTER.}

Lithologically the Valdez rocks are remarkably uniform throughout the area in which they occur. They consist in large part of slates and graywackes, commonly in alternating beds (Pl. V, $A, \mathrm{p} .38$ ). The average thickness of the individual beds differs from place to place, ranging from a few inches to 50 feet or more. The proportion of the slates to the graywackes also ranges within wide limits and one or the other phase may locally be greatly predominant. In the Ellamar district the beds average perhaps a foot or two in thickness and the slates seem to be somewhat more abundant than the graywackes, though over considerable areas they are nearly equal in amount. As deposited the rocks consisted of gray to black muds and lightercolored feldspathic sands. These were later cemented and compressed into shales and graywackes, and the whole series was subsequently metamorphosed by folding and faulting into the existing slates and graywackes. The slates vary in appearance, their color ranging from black to bluish or gray. The black rocks are carbonaceous. In some of these rocks slaty cleavage is little developed, but in others it is very conspicuous, though it rarely approaches the per- 
fection necessary to form roofing slates. In places where the cleavage is best developed the rocks have been partly recrystallized and secondary minerals have been formed, the most abundant being muscovite. In those places it is difficult to distinguish the original bedding planes of the slates, for the schistosity may cut across the bedding at any angle and obscure it. Grant ${ }^{1}$ observed that slates near granitic intrusives have in many places been altered to nodular schists, or "knotenschiefer," containing abundant biotite. No granitic rocks occur in the Ellamar district, but phases of the slates which approach "knotenschiefer" in composition and appearance were seen near the head of Landlocked Bay, and they may be due to the presence of an intrusive mass of granitic rock which did not reach the surface and which is not exposed.

The slates and graywackes were originally brought down as detrital material from a land mass on which mechanical erosion was active, for the materials of which they are composed differ from those derived from an old land surface on which stream cutting was slow and chemical action was the chief disintegrating force. On such an old land surface many of the minerals of the rocks break down into simple compounds and the soluble portions are removed, leaving the residual clays and the resistant quartz. The Valdez rocks, however, are largely the products of mechanical disintegration, for they contain particles of many minerals which under other conditions would have decayed. The slates are generally of too fine grain to permit their constituent particles to be distinguished, even under a microscope of high power. The graywackes, however, are of coarser texture, and contain, in addition to quartz, particles of feldspar and ferromagnesian minerals. - Many of the grains are angular and are cemented by a matrix of clayey material or secondary quartz, mica; and chloritic material. The rock is commonly gray or blue-gray, is finely quartzitic to coarsely granular in texture, and is generally massive and very hard. Some of its phases may easily be mistaken in the field for a fine-grained dike rock. It has withstood the stresses to which it has been subjected much better than the slates with which it is associated, for in places these show a highly developed cleavage, whereas the adjacent graywacke is still massive. Some of the graywacke beds are discontinuous and are really broad, flat lenses, thinning out at the edges: None of those seen had sufficient individuality to make them identifiable for any considerable distance. In places the graywacke has become somewhat schistose, and where it is associated with sheared greenstone may easily be confused with it.

No igneous rocks of Valdez age were seen. The slates and graywackes have in places been cut by dikes, but these are plainly of much later age than the rocks into which they have been intruded.

1 Grant, U. S., and Higgins, D. F., op. cit., p. 22. 
STRUCTURE.

The Valdez rocks are reported by Grant ' to be generally closelý folded, the closeness of the folds and the metamorphism of the rocks increasing from south to north, toward the axis of the range. In the Ellamar district their prevailing strike is northwestward, parallel to their contact with the Orca group, and is rather uniform, varying only a few degrees throughout large areas. The dip is less uniform, ranging in general from $30^{\circ} \mathrm{N}$. to vertical, but commonly $50^{\circ}-70^{\circ} \mathrm{N}$. There is evidence, however, that the beds do not form a continuous series dipping northward in their original stratigraphic succession, for many close, sharp folds were seen, so closely compressed that there was little arching at the crest of the folds, and the limbs lay parallel to one another. Grant interprets the structure in Port Valdez as consisting of closely folded synclines and anticlines overturned ti- the south, giving monoclinal dips to the north. This seems to be the condition in the Ellamar district also. On this major folding one or even two sets of minor folds have locally been superposed, complicating the structure.

At many places folded Valdez rocks have been cut by faults, which are therefore later than the folding. Many of these faults cut rocks of marked lithologic uniformity, so that the amount of displacement can not be determined, and for this reason also many faults of considerable magnitude may have escaped detection altogether. One great fault, however, has had a marked effect on the distribution and rela-: tion of the Valdez and Orca groups. This is an overthrust fault along which the older Valdez rocks have been thrust up over the greenstones of the Orca group and which forms the contact of these groups for several miles. For the purpose of description it is here called the Landlock fault. It crosses the head of Landlocked Bay and runs northwestward into the basin of Bottle Creek. Its continuation northwest of Bottle Creek could not be closely traced, but it must cross the head of Galena Bay and probably continues northwestward to Valdez Arm. The fault is inconspicuous, for it runs parallel to the bedding of the slates and graywackes of the Valdez group and also lies parallel to the surface of the greenstone of the Orca group in Landlocked Bay, giving the rocks a deceptive appearance of stratigraphic conformity. Around the head of Galena Bay the situation is even more confusing, for the rocks on both sides of the fault are similar slates and graywackes. There can be little question that the fault exists in that locality, however, for some of the slates lie with true conformity below the greenstones and others are with little doubt of much greater age. The movement along this fault zone did not take place as a single sharp break but was distributed through a considerable thickness 
of beds, and the rocks for a width of several hundred yards show evidence of great shearing. The fault line as mapped is therefore not the trace of a single plane of movement but has been so placed on the geologic map (Pl. II, in pocket) as to show approximately the contact between the overriding and overridden rocks. In interpreting the map, it must be remembered that the movement was distributed through the rocks for several hundred feet on either side of this line. Though the total displacement was great, the shifting between adjacent beds was not necessarily great but is believed to have been taken up in some such way as.may be illustrated by sliding a pack of cards between the hands. The movement between the top and bottom cards may be considerable, but that between any two successive cards may be small.

None of the faults seen are marked by recognizable fault scarps, for most of the faulting occurred before the present topography was formed, and any fault scarps that may have existed have been obliterated by erosion by streams and glacial ice.

THICKNESS.

Little definite information is available concerning the thickness of the rocks that form the Valdez group. Rocks that are believed to be of this age extend from Galena Bay northward to Klutina Lake, a distance of over 50 miles across the strike of the beds, and throughout much of this distance the beds are tilted at high angles. It is at present impossible, however, to compute the actual thickness of sediments, for the beds are closely folded and intricately faulted and may have been reduplicated many times in any section across the range. It can only be stated that the Valdez group is certainly many thousand feet thick.

\section{AGE AND CORRELATION.}

The age of the Valdez rocks has not yet been definitely determined. The only fossils yielded by beds of this group are some plant remains which were so badly áltered that their age could not be determined. Geologists who have attempted to fix their age by their stratigraphic relations have provisionally assigned these rocks to horizons ranging from the Silurian to the Tertiary. In the light of later investigations, however, the position of the group can be fixed more definitely. Moffit ${ }^{1}$ has found the Valdez rocks east of Copper River to lie, with apparent unconformity, on limestone of Paleozoic and probably Carboniferous age. Grant ${ }^{2}$ says that the Valdez group lies unconformably below the Orca group, in which fossils of possible Jurassic age have been found. If, therefore, the rocks reefrred to by Moffit

\footnotetext{
1 Moffit, F. H., Geology of the Hanagita-Bremner region, Alaska: U. S. Geol. Survey Bull. 576, pp. 17$18,1914$.

2 Grant, U. S., and Higgins, D. F., Geology and mineral resources of Prince William Sound, Alaska:

U.S. Geol. Survey Bull. 443, p. 24, 1910,
} 
and Grant as belonging to the Valdez group are of the same age, they must be late Paleozoic or early Mesozoic, and they are probably, in part at least, late Paleozoic. In $1913 \mathrm{~B}$. L. Johnson found in the Port Wells district a number of localities within rocks which had formerly been mapped with the Valdez group, at which he collected fossils that may be of Mesozoic age. Diagnostic fossils are rare within the area of so-called Valdez rocks, but wherever found they serve to cast doubt on the Paleozoic age of this group. It seems probable that future investigations may restrict even further the areas of these rocks that may be referred to the Paleozoic.

\section{ORCA GROUP.}

\section{DISTRIBUTION.}

The Orca group was first studied and named by Schrader ${ }^{1}$ in' 1898 and has since been discussed by Schrader and Spencer ${ }^{2}$ and more recently by Grant and Higgins. ${ }^{3}$. In general the rôcks of this group lie south of the Valdez rocks, though some isolated areas of Orca beds surrounded by those of the Valdez group have been mapped.* In the western part of the Prince William Sound region the Orca rocks form a group of islands which are separated from the mainland of Kenai Peninsula by Bainbridge and Knight Island passages. More or less isolated areas have been outlined at Resurrection Bay and at Unakwik Inlet, but east of Columbia Glacier the Orca rocks form a large part of the mainland and the width of the belt increases toward the east. In the area east of Landlocked Bay the northern border of the Orca rocks is not well known, but they extend eastward to Copper River and constitute a large element of the coastal mountains. In Kenai Peninsula and north of Turnagain Arm the Sunrise group contains some beds of Mesozoic age which perhaps should be correlated with the Orca group, but their area is not known.

In the Ellamar district all the rocks lying southwest of the Valdez group are placed in the Orca group (Pl. II, in pocket). This includes the rocks on both sides of the mouth of Galena Bay and those that border the shores of Tatitlek Narrows, Virgin and Boulder bays, all of Landlocked Bay but its head, and all of Bligh and Busby islands. Beyond the limits of the Ellamar district as mapped the Orca rocks are probably continuous to the west with the area shown by Grant ${ }^{4}$ between Valdez Narrows and Point Freemantle and to the east with the Orca rocks in Ports Fidalgo and Gravina, Sheep Bay,

\footnotetext{
1 Schrader, F. C., A reconnaissance of a part of Prince William Sound and the Copper River district, Alaska, in 1898: U. S. Geol. Survey Twentieth Ann. Rept., pt. 7, pp. 404-408, 1900.

2 Schrader, F. C., and Spencer, A. C., The geology and mineral resources of a portion of the Copper River district, Alaska: U. S. Geol. Survey special pub., pp. 37-44, 1901.

${ }^{3}$ Grant, U. S., and Higgins, D. F., Reconnaissance of the geology and mineral resources of Prince William Sound, Alaska: U. S. Geol. Survey Bull. 443, 1910, pp. 25-53.

1 Grant, U. S., and Higgins, D. F., op. cit., pl. 2.
} 
and the type locality in Orca Bay. They probably underlie most of Prince William Sound and are thus continuous with the Orca exposures on Knight, Montague, and Hinchinbrook islands.

CHARACTER.

LITHOLOGIC DIVISIONS.

The Orca group, considered as a whole, differs widely from the Valdez in that it consists of an assemblage of rocks of diverse lithologic character. These rocks are black slates, interbedded slates and graywackes, some limestones, greenstones ranging from rather course diabasic intrusives to ellipsoidal lava flows (including volcanic agglomerates), and conglomerates and grits of several ages and types. This assemblage characterizes the group throughout its extent, but the preponderance of the different rock types differs greatly from place to place. Over considerable areas one type may be present to the exclusion of the others. At other places any two or all of the different kinds of rock may be intimately associated.

In the Ellamar district all the above types are represented. The -determination of the stratigraphic order in which the rocks were deposited presents many difficulties, for the original order has been complicated by folding and faulting. The rocks in many areas: where two types are associated are concealed by vegetation, and the contacts in many other localities are below the surface of the sea, so that the relations between the islands and the mainland or between the two sides of a bay can not be directly observed. Some errors may therefore have crept into the: interpretation of the stratigraphic sequence as given in the columnar section (fig. $3 ;$ p. 27 ), but so far as could be ascertained the order is as shown in the'section. It is doubtful whether the succession was everywhere the same within the borders of the basin in which the Orca beds were deposited. It seems more probable that while the slate-making sediments were being laid down at one place, beds that were afterward changed to slates and graywackes were laid down at some distant point. The lava flows that made the greenstones certainly covered circumscribed areas; they were poured out in some places while sedimentary deposition elsewhere was uninterrupted. The conglomerates also were probably of rather local development and at many places are lacking. It therefore seems certain that a section worked out for one locality will differ to some extent from another section some miles distant, and the failure of two such sections to correspond does not necessarily mean that either interpretation is incorrect. Some of the larger features, however, such as the position of the greenstones with relation to the overlying and underlying beds probably agree in different parts of the field. 
LOWER BLACK SLATES.

The oldest rocks of the Orca group in the area here considered consist of a thick series of black slates, which reaches its greatest development on Bidarka Point and on the north side of Tatitlek Narrows near the village of Tatitlek. This slate series is characterized by its freedom from interbedded graywacke beds, those seen being thin and forming only a very small proportion of the whole thickness. The slates are predominantly black and have a well-developed cleavage which strikes northwestward and at most places dips steeply to the north. The bedding is inconspicuous but in places can be distinguished as a banding, the adjacent bands having slightly different colors on weathered surfaces. The bedding is less regular in strike and dip than the cleavage but commonly strikes parallel to it and dips at a greater or less angle to the northeast. The strike and dip of the cleavage is conspicuously regular and may easily be mistaken for the bedding, which is inconspicuous.

The thickness of these slates is difficult to determine, for the exposures are nowhere continuous from the top to the bottom and the structure is complex. The widest exposures across the strike of the beds are on Bidarka Point, where for 3 miles the beds dip steeply to the northeast at angles of $45^{\circ}$ to $85^{\circ}$. This inclination would indicate a thickness of more than 10,000 feet, which may be far in excess of the true figure, for folding and faulting may have repeated the beds.

LOWER SLATES AND GRAYWACKES.

On the northeast side of Tatitlek Narrows the black slates are overlain by a series of slates and graywackes which are best exposed along the bed of Gladhaugh Creek. The Orca group in the Ellamar district contains two series of interbedded slates and graywackes, one below and the other stratigraphically above the greenstone. The upper series is discussed elsewhere (pp. 43-44). The beds of the lower series are prevailingly thin, at most places only a few inches and nowhere more than a few feet thick. The graywackes and slates are approximately equal in quantity, though locally one or the other may predominate. This series is exposed in the Ellamar mine, where some black limestones are interbedded with the other sediments. On Bidarka Point the typical slates and graywackes are missing between the black slates and the greenstone. The greenstone overlies the slates and has about the same strike and dip, but the exposures are not good, and the slates and graywackes may have been cut out by faulting. Near the base of the greenstones there are some massive cherty-looking beds, some of which appear under the microscope to be fine-grained altered graywackes and some of which may be greenstone tuffs. These may be the altered equivalent of a part of the 
slate-graywacke series, but the greater part of this series seems there to be lacking.

On the east side of the mouth of Landlocked Bay, and eastward to the edge of the area shown on the map (Pl. II, in pocket), rocks which are believed to be of this same series outcrop. They consist essentially of slates and graywackes, but at two localities conglomerates are interbedded. The possible significance of these conglomerates is not known. They were found only in small exposures on the beach and could not be traced inland on account of the heavy cover of vegetation and glacial deposits. They may represent important unconformities within the series, but it seems more probable that they merely represent episodes in the deposition of the series of slates and graywackes, which are themselves essentially shallow-water deposits.

The slate-graywacke series as a whole has a remarkably close resemblance to the rocks of the Valdez group. In upper Gladhaugh Creek the rocks dip to northwestward beneath the greenstones of Ellamar Mountain, and they outcrop on the south side of upper Galena Bay with the same relation to the greenstone. Yet in a careful study of the rocks around the head of Galena Bay the writers were unable to detect the transition from these Orca rocks to the Valdez rocks which form the north side of the bay. The relation between the two groups is here one of faulting and folding, but the fault, which places two similar rock groups together, could be mapped only approximately.

This slate-graywacke series may be several thousand feet thick, but the same difficulties are met in estimating its thickness as in estimating the thickness of the black slates and of the Valdez group. Folding has occurred and faulting is known to have been extensive, so that any section measured may be greater or less than the original thickness of the beds.

This slate-graywacke series has been faulted and folded about as much as the black slates but more than the overlying harder greenstone. In any stresses which were set up within the whole Orca group, the rigid greenstones have imposed much of their share of folding or faulting on the less resistant beds of the group, and the slate and the lower slate-graywacke series have suffered accordingly. Between Graveyard Point and Fish Bay the beds have been intensely deformed. Excellent exposures along the beach show that the interbedded slates and graywackes stand on edge and are closely and intricately folded. In other places, as on upper Gladhaugh Creek, they are not so greatly deformed, and the strike and dip may change little over considerable areas.

The relations of the lower slate-graywacke series to the underlying black slate are not well known, for no exposures of the contact between them were seen. In general the strikes and dips of the 


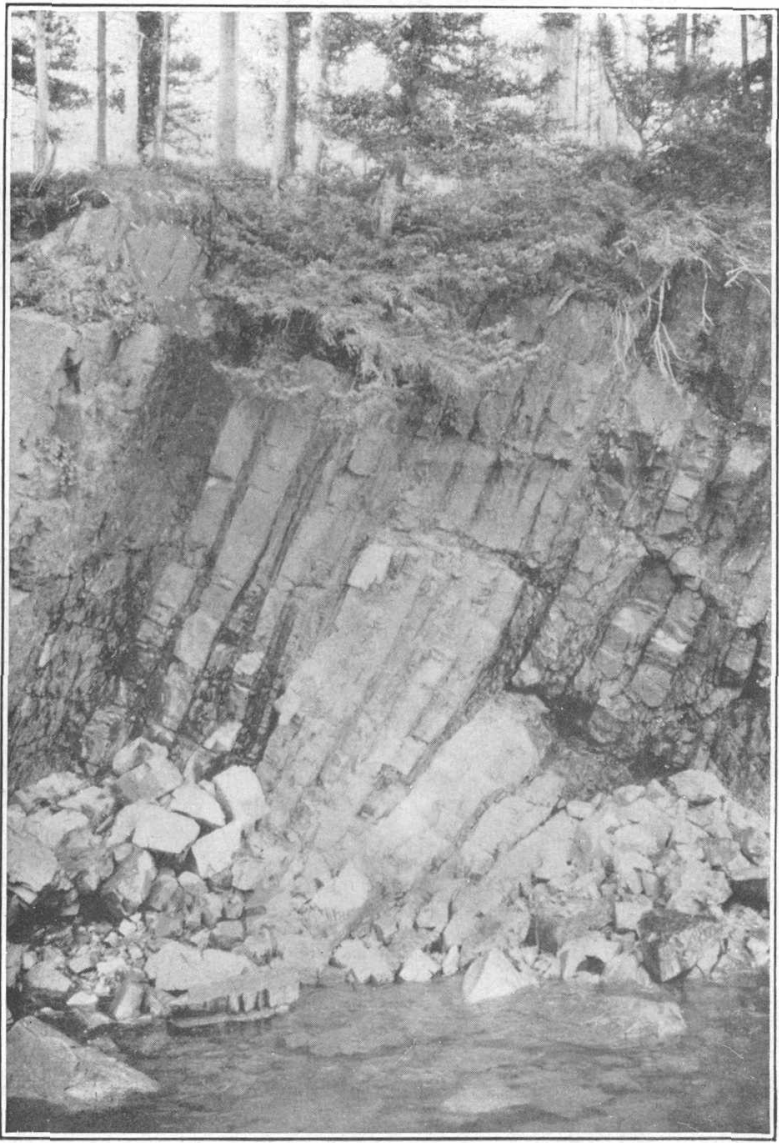

A. STEEPLY DIPPING SLATE AND GRAYWACKE BEDS OF THE VALDEZ GROUP.

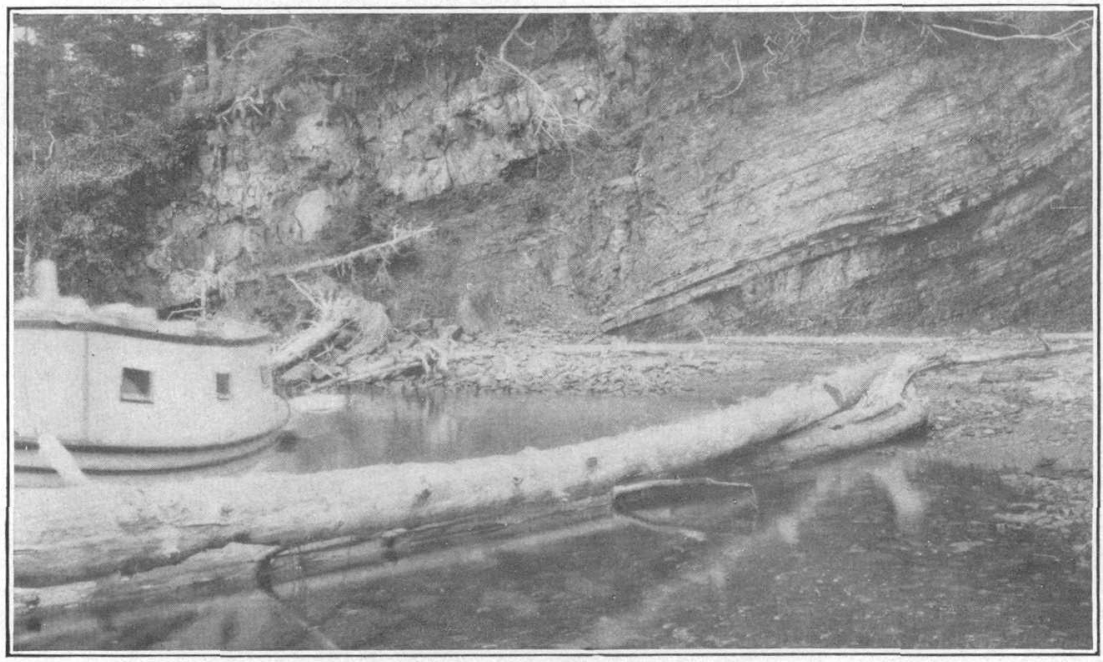

B. SLATES AND GRAYWACKES OF THE ORCA GROUP CONFORMABLY OVERLAIN BY DIABASE FLOWS. 


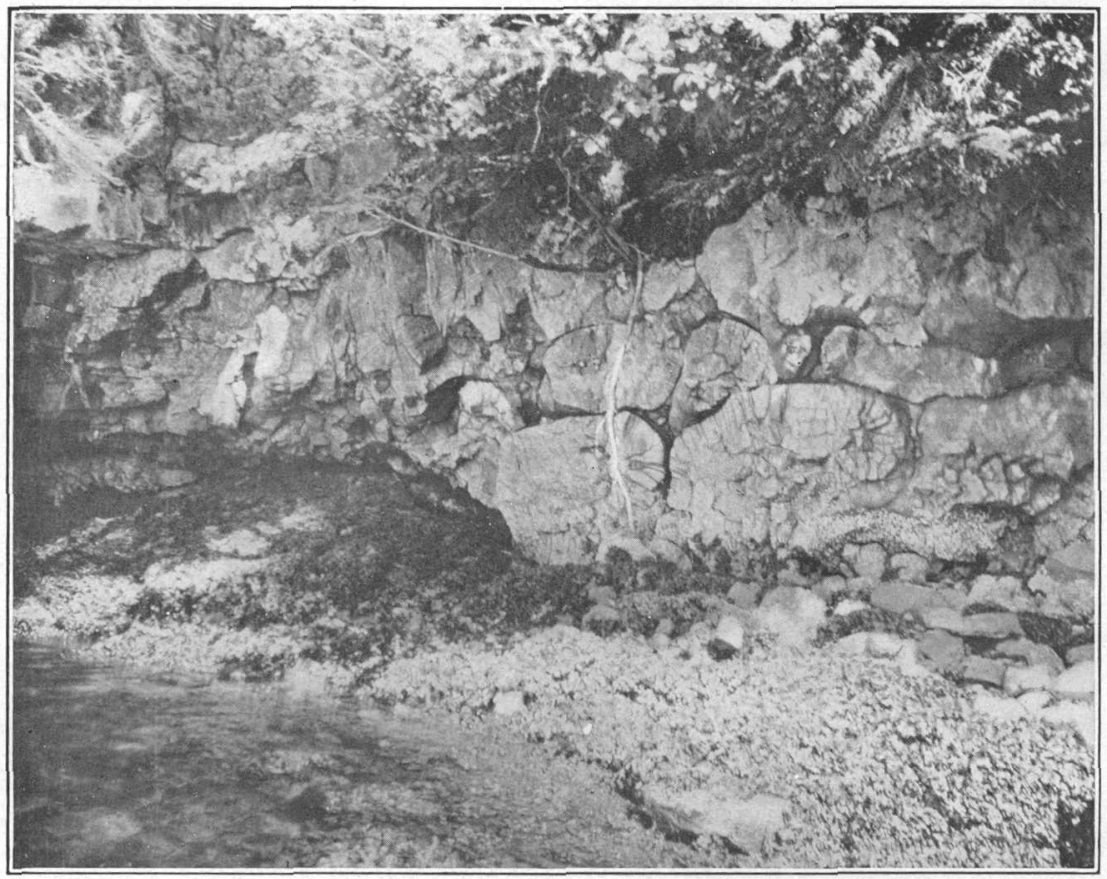

A. CROSS SECTION OF ELLIPSOIDAL GREENSTONE BED NEAR ROCKY POINT.

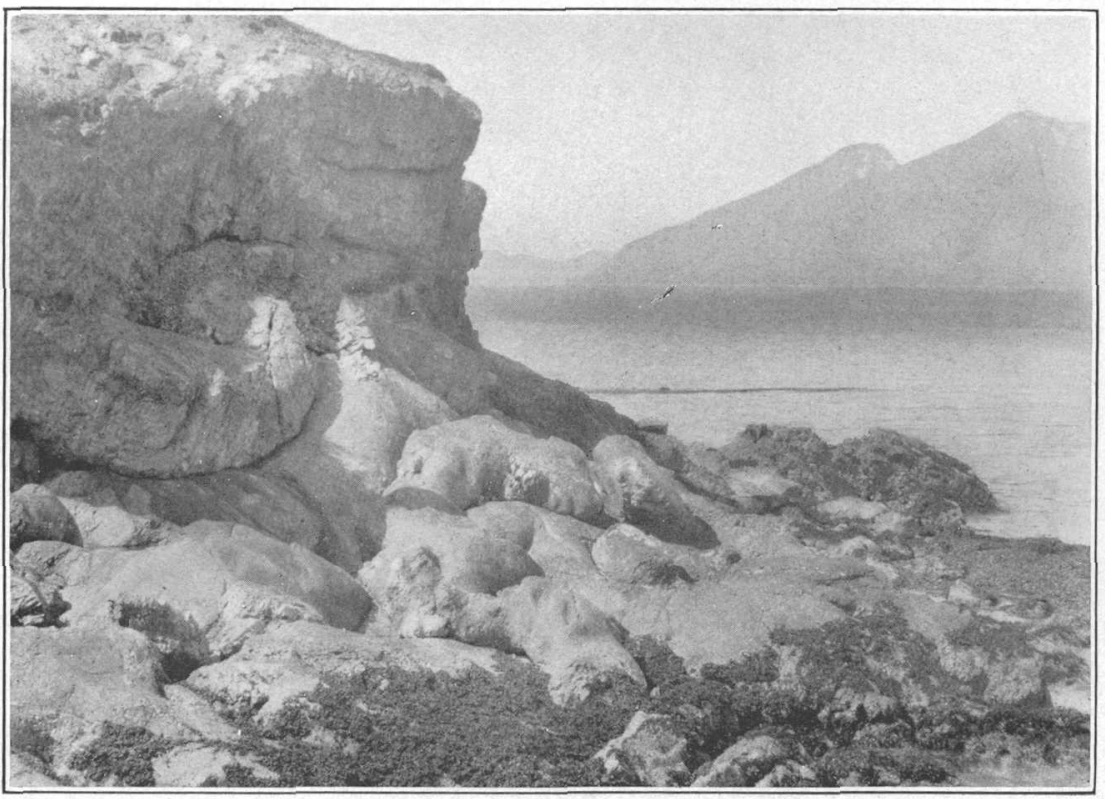

B. ELLIPSOIDAL GREENSTONES IN SECTION AND PLAN NEAR ROCKY POINT, 
two divisions are about the same in near-by areas, and it is believed that they are conformable. The contact between the lower slategraywacke series and the overlying greenstone is beautifully exposed on the south shore of Galena Bay. There the lowest greenstones are ellipsoidal lava flows, which were probably poured out on the sea bottom, interrupting the deposition of the sediments. The bottom. of the greenstone flow has conformed to the shape of the bottom on which it rested, the ellipsoids being flattened on the lower side, and the base of the greenstone is parallel with the bedding of the slates, so that it is certain that there is structural conformity between the two and that the greenstone is younger than the slates and graywackes.

\section{GREENSTONES.}

Occurrence.-The greenstones lie conformably upon the lower slate and graywacke series, and although, on account of their great thickness and extent, they are here considered a separate unit, they may be thought of as occurring in the upper part of the slate-graywacke series and as consisting of a number of lava flows which were intercalated between the slate and graywacke beds, but which did not stop their deposition. (See Pl. V, B.) The greenstones as here defined include all the beds from the lowest greenstone flow to the base of the conglomerate but contain numerous relatively thin beds of slate and graywacke that were laid down between the separate lava flows.

Primarily the greenstone was a series of basaltic lava flows that were poured out on a sea bottom in which muds and sands were accumulating. Some of the greenstone beds are massive, but wherever they have been but little deformed the rock is generally ellipsoidal. (See Pl. VI, $A$ and $B$.) Ellipsoidal greenstones ' have been generally regarded as basic lava flows that were poured out at the bottom of a body of water, the flowing and cooling of the lavas under water causing the formation of these unusual ellipsoidal or spheroidal forms. (See Pl. VII, A.) Observations made in this district strongly support the theory of the subaqueous origin of ellipsoidal lavas. At many places where the contact between greenstone flows and the interbedded slates could be observed it was apparent that the lavas had flowed out upon a bed of soft mud and that the bottom of the flow had conformed to the surface of the mud bed, the contact between the two being conformable. (See Pls. VII, $B$, and VIII, $A$.) Figure 4 illustrates the conditions, shown in part in Plate VIII, $A$. The ellipsoids at the base of the flow. are flattened on the bottom but rounded on the other sides, and the boundaries of the lower

: 1 Capps, S. R., Some ellipsoidal lavas on Prince William Sound, Alaska: Jour. Geology, vol. 23, pp. 45-51, 1915. 
ellipsoids and the fragments into which each ellipsoid has broken on cooling are outlined by a thin film of black material, which is of the same composition as the underlying slates. The mud, which must have been soft and plastic at the time the lava was poured out, was forced into the openings and cracks formed in the lava as it cooled and shrank.

The upper surfaces of the flows present a different appearance. The top of the lava bed was under no. pressure except that of the water, and the surface hardened to form an irregular floor-consisting of a succession of domes, resembling the surface of a magnified cob-

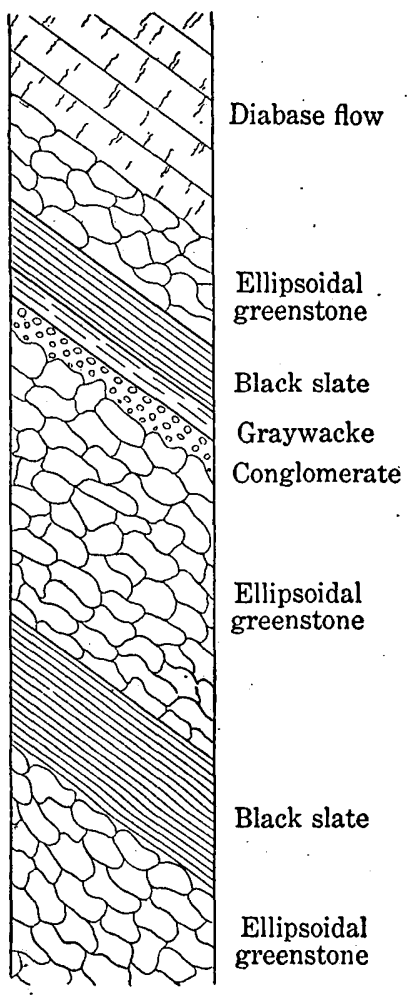

Figure 4.-Relations between ellipsoidal greenstone flows and interbedded sediments. Scale, $1 \mathrm{inch}=10$ feet. blestone pavement, the surfaces of the ellipsoids representing the cobblestones. On this surface more muds were deposited, and the bottom of the mud took the shape of the irregular lava surface. The surface of the lava shows no signs of weathering or erosion, and this fact adds weight to the conclusion that the lavas and interbedded sediments were deposited successively under water. Furthermore, the difference in the surface of the top and bottom of certain lava beds makes it possible to determine the stratigraphic sequence of the series, a fact of great significance in interpreting the structure in a region of great folding and faulting.

Distribution.-In the Ellamar district the greenstones form the most widespread part of the Orca group. From the north side of the mouth of Galena. Bay they extend southeastward beyond the constriction in the center of the bay. This area is doubtless continuous with the larger area between Galena Bay and Tatitlek Narrows, where the greenstones form the high ridges. that center in the Ellamar Mountains.

East of Boulder Bay the greenstones also form the high ridges leading to Copper Mountain and extend across Landlocked Bay in a gradually narrowing belt to the edge of the area mapped. Busby Island and the northeastern part. of Bligh Island are also composed of greenstone.

Character.-The greenstones comprise rocks that present a widely different appearance and a considerable range in composition. They were for the most part laid down as lava flows, but differences in the thickness of the flows and in their rate of cooling have affected the 


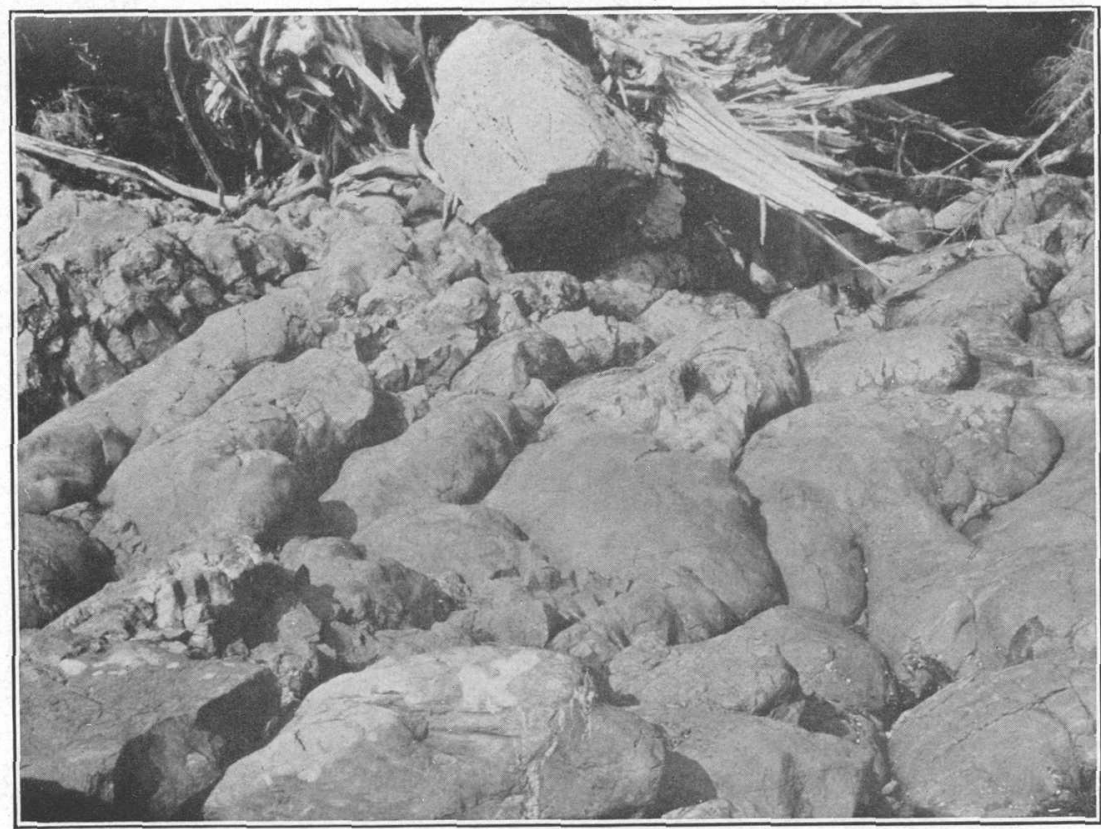

A. IRREGULAR-SHAPED FORMS OF ELLIPSOIDAL GREENSTONES IN PLAN, EAST END OF BLIGH ISLAND.

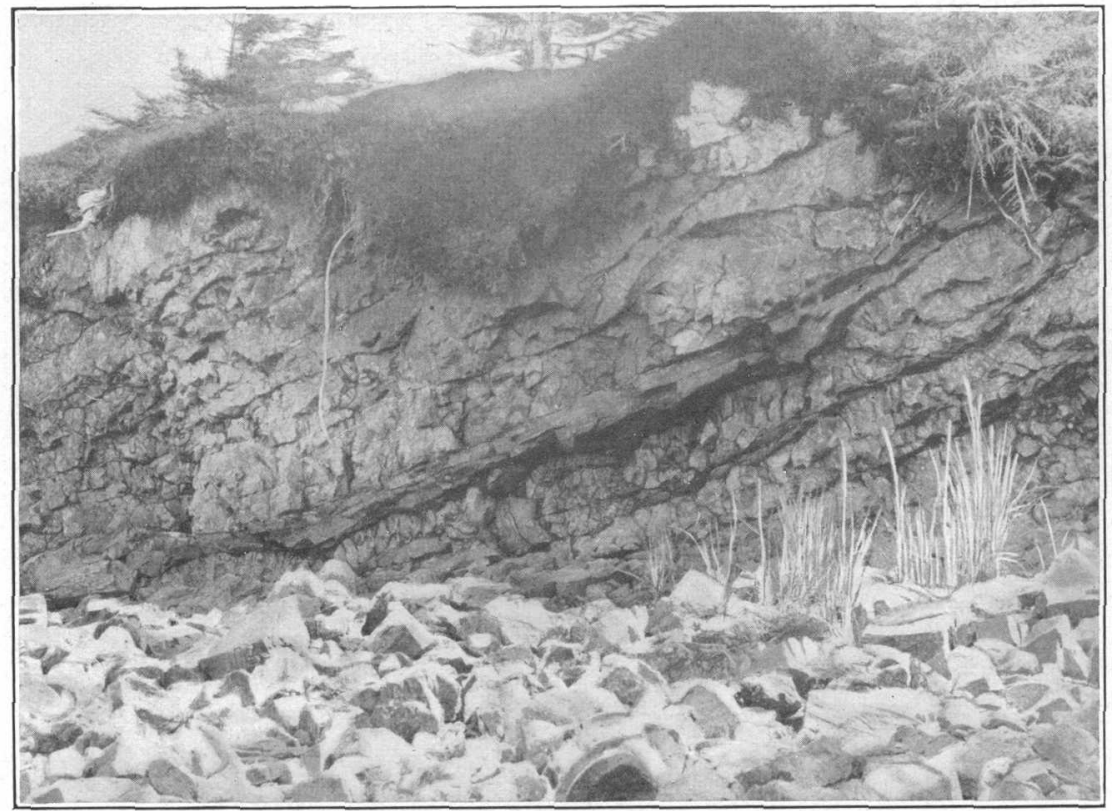

$B$. SHALE INTERBEDDED WITH ELLIPSOIDAL GREENSTONE.

Shows irregular lower surface and smooth upper surface of shale bed. 


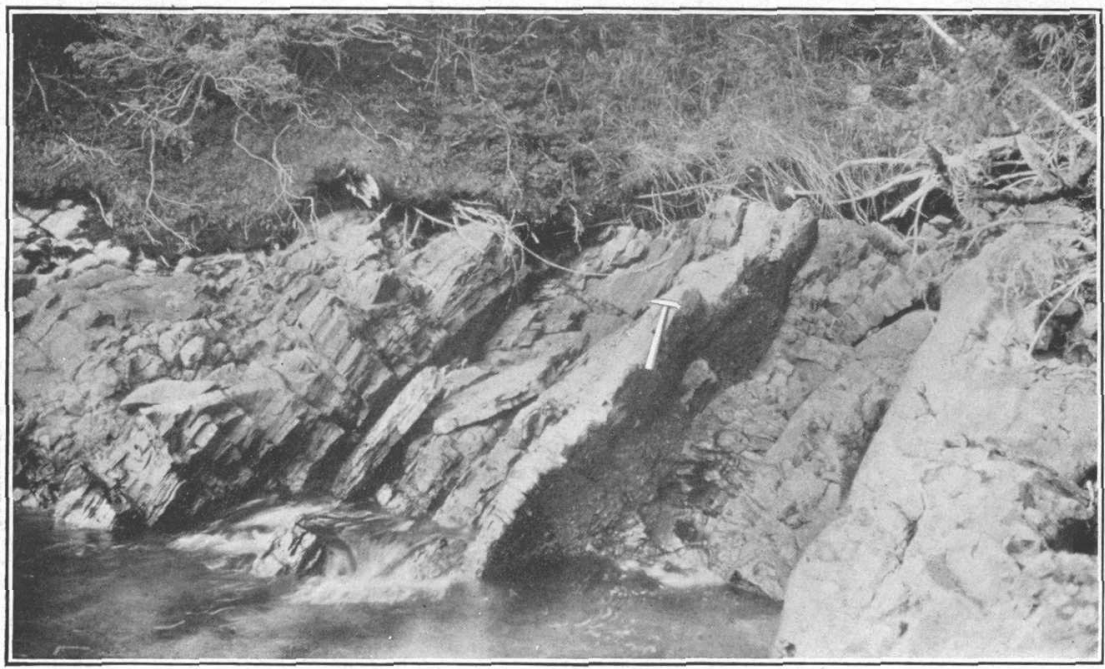

A. ELLIPSOIDAL GREENSTONE (ON RIGHT) SUCCEEDED BY CONGLOMERATES AND SHALES, WHICH ARE THEMSELVES OVERLAIN BY LAVA FLOWS.

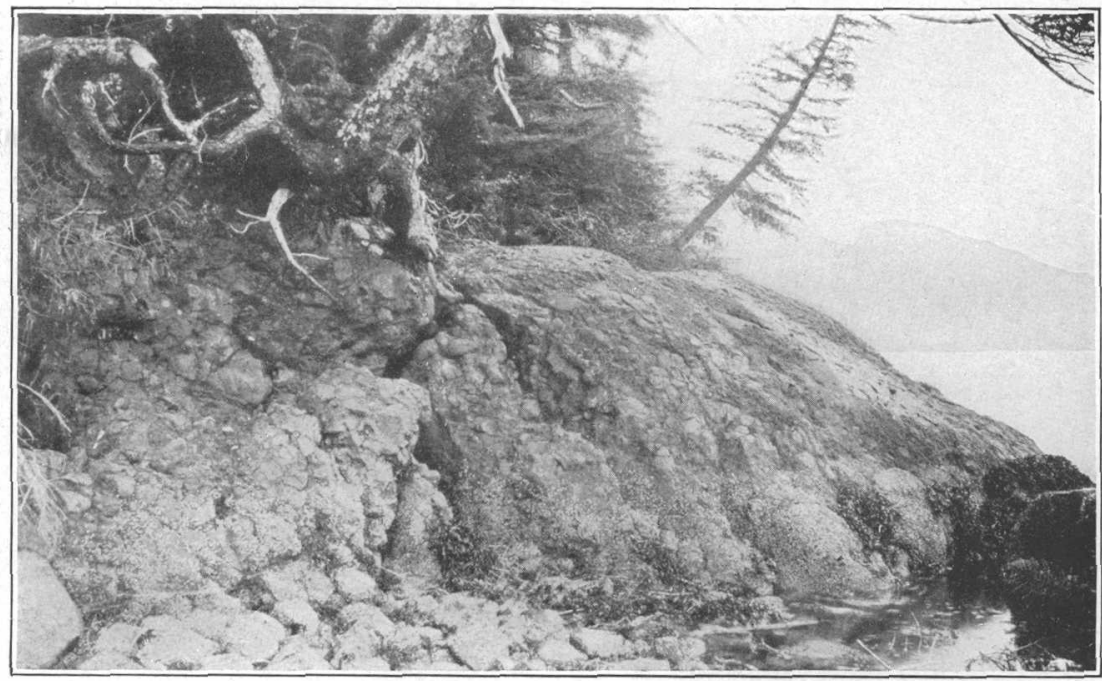

B. VOLCANIC BRECCIA ON NORTH SIDE OF GALENA BAY NEAR MOUTH. 
character of the rock which varies from fine-grained basalt, seen in the ellipsoidal flows, to rather massive diabase of coarser crystalline texture. The ellipsoidal beds are best developed north of the entrance to Galena Bay and along both shores of the lower half of the bay, in Tatitlek Narrows for 2 miles north of Black Point, and on the northeast shore of Bligh Island, at localities where the rocks have not been greatly metamorphosed and where their original appearance has been preserved. On the east side of the head of Boulder Bay and near the mouth of Galena Bay (PI. VIII, $B$ ) the greenstones include, besides ellipsoidal flows, thick beds of volcanic agglomerate, consisting of irregular angular fragments of lava inclosed in a matrix of the same material. The fragments range from microscopic bits to blocks several feet in diameter and are generally of a different color from the matrix, so that the rock presents a pronounced mosaic appearance.

Farther southeast, at Copper Mountain and east of Landlocked Bay, the greenstones have been deformed and greatly sheared, so that their ellipsoidal character has in many places been obscured or effaced. At Copper Mountain many beds of the greenstone are dense and massive and closely resemble cherts, from which they can be distinguished only by the aid of the microscope. The cherty-looking beds range in color from green to gray; and in some beds both colors are intimately interbanded. A study of thin sections shows that some of the beds are altered graywackes and that others are fine-grained tuffs. In many places the lavas have been metamorphosed to serpentines, especially on the south side of Copper Mountain and in the neighborhood of the great fault that limits the greenstone on the northeast.

North of Copper Mountain, between the basin of Mallard Creek and a line extending northward from the head of Boulder Bay, there is a complex of sheared and metamorphosed rocks which are believed to belong to the greenstones of the Orca group but which differ from those seen in other parts of the district. The rocks consist of serpentinous greenstones and of sedimentary beds which have been so altered that their original character is lost. They are now siliceous quartzitic rocks, which have been minutely fractured and the fractures filled with quartz. A great thickness of greenstones and sediments has been sheared and folded together. The outlines of this complex are not well known, for it is bordered on the east, north, and west by timbered stretches in which outcrops are poor or lacking. The area is probably limited on the north by the fault, which has been tr ced to the southeast.

o st north of Black Point, in Tatitlek Narrows, is an exceptionally thick series of slates, with a few thin flows of greenstone interbedded. Along the beach the slates outcrop for about 1,000 feet across the 
strike of the bedding, and the material is mostly slate with a very small proportion of graywacke and one 3-foot bed of hard conglomerate with slate pebbles in a gritty matrix. In attempting to trace the eastward extension of this slate series exposures could be found only along the creek bed, but it appears that the slates are continuous for only about a mile along the strike and consist of a wedge-shaped mass interbedded with the lava flows. It is barely possible that this slate belt extends across the ridge into the basin of Gladhaugh Creek, but the heavy cover of vegetation makes the tracing of the contact difficult, and from the observations made the slates were not seen to extend outside the basin of Black Creek.

The greenstones of the Orca group are associated at a number of places with massive basic rocks, which, though of about the same chemical and mineralogic composition as the ellipsoidal greenstones, are much more coarsely crystalline and probably cooled slowly below the surface and were not extruded as lavas. The most important occurrence of this kind is on the long island in Tatitlek Narrows southwest of Tatitlek village. The diabase mass cuts the black slates and was probably contemporaneous with the lava flows, possibly representing one of the vents from which they emerged. The intrusive rocks are described on pages 48-49.

CONGLOMERATE.

Distribution.-As the top of the greenstones is approached, near the narrow low gap $1 \frac{1}{2}$ miles southeast of Rocky Point, the slate beds alternating with the greenstone flows become more numerous, small quantities of limestone occur, and thin conglomerate beds appear between the thin lava beds. Above the last greenstone flow a very thick conglomerate occupies all the end of the peninsula between Galena Bay and Tatitlek Narrows. It lies conformably on the underlying greenstones, and although the conditions of sedimentation were greatly changed, coarser materials being carried into the sea and volcanic activity having ceased, it is believed that no time elapsed between the deposition of the greenstones and that of the conglomerate, but that deposition was continuous. The area of land surface now occupied by this conglomerate is not large, but its actual extent may be many times greater than that shown on the map. Islands both north and south of the mouth of Galena Bay are composed of this conglomerate, and it may have a considerable areal extent beneath the waters of Valdez Arm. Excellent exposures occur on the east shore of the small bay just north of Galena Bay, but the conglomerate at that place has probably been.faulted into its present position.

Character.-On the map (Pl. II) the conglomerate of the Orca group is shown by a single color, but the rocks differ greatly in appear- 


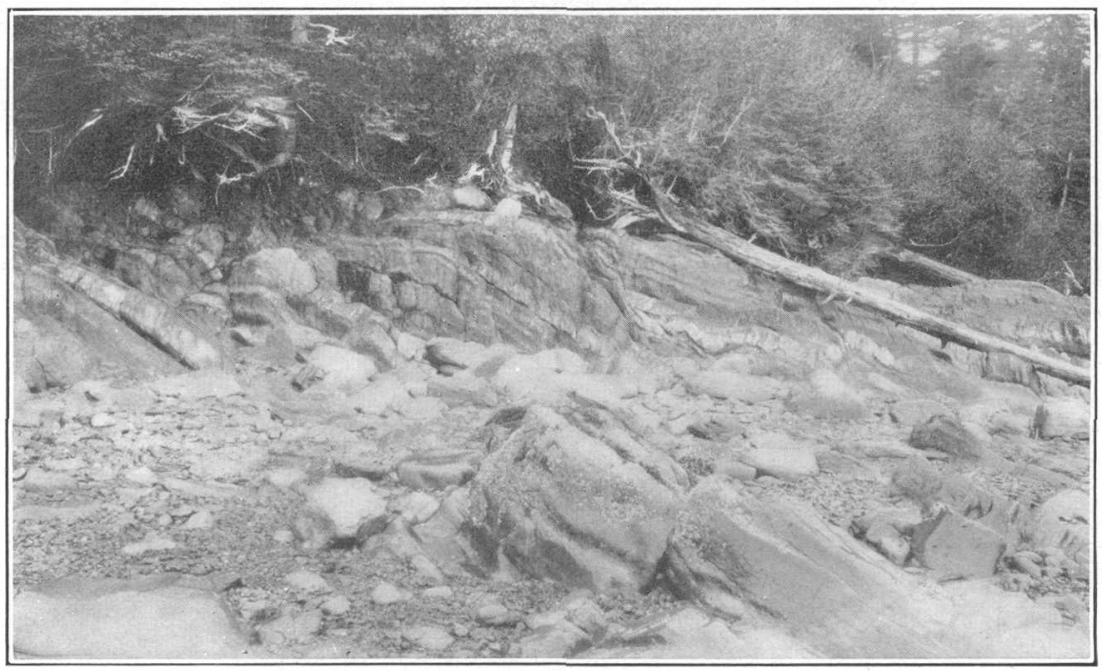

A. TILTED AND SLIGHTLY FOLDED SLATES AND GRAYWACKES OF ORCA GROUP ON THE SOUTHEAST SIDE OF BLIGH ISLAND.

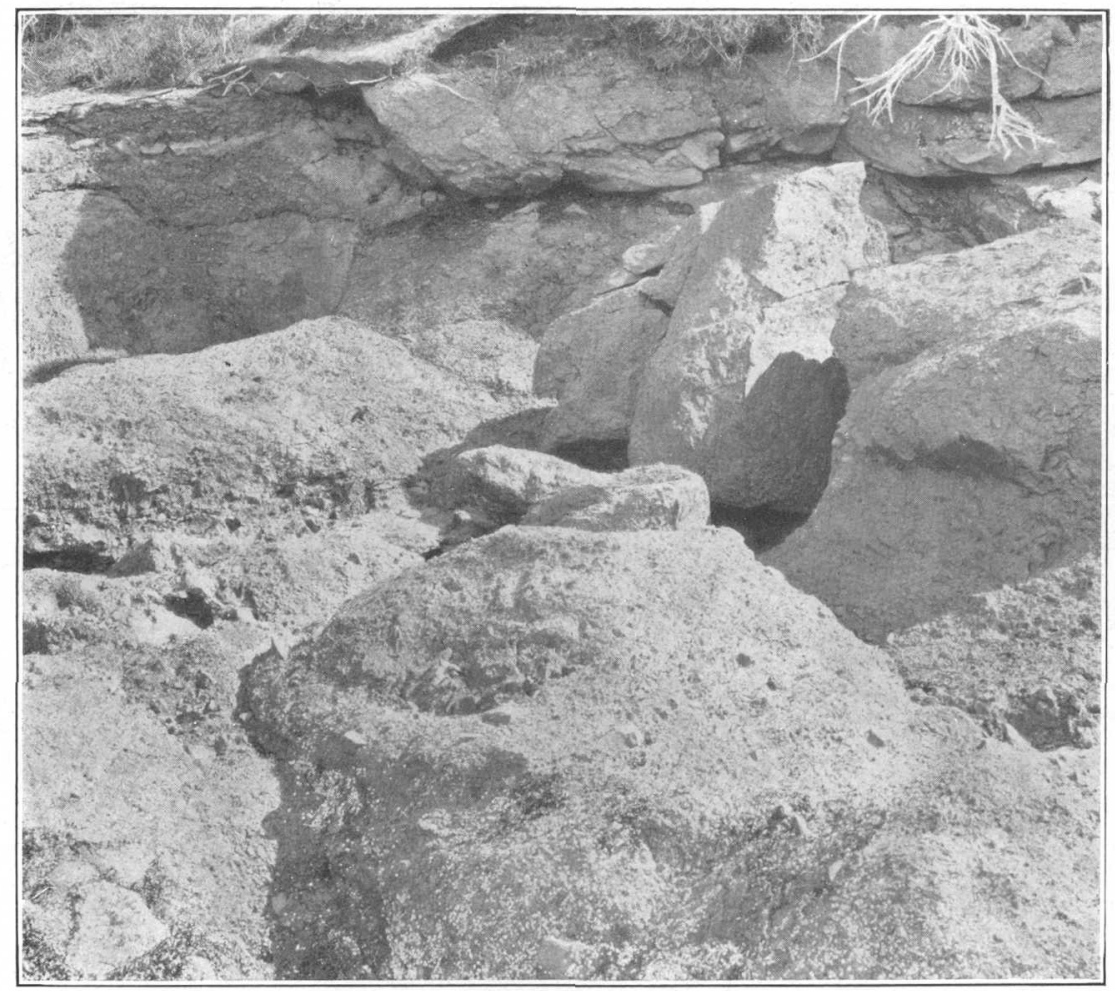

B. COARSE MASSIVE PHASE OF CONGLOMERATE OF ORCA GROUP NEAR ROCKY POINT. 
ance at different exposures. In general they are firmly cemented, and a fractured surface of a fresh specimen may show the included pebbles to have broken with the matrix. Where weathered the matrix is less firm, and the rock breaks around the surface of the pebbles. The texture of the rocks varies from gritty beds, which approach coarse sandstone in appearance, to coarse massive conglomerates containing bowlders and blocks of rock several feet in diameter (Pl. IX, $B$ ). Between the pebbly beds in places occurs a little slate and graywacke. The pebbles in the conglomerate are composed mainly of graywacke or slate, though some crystalline pebbles of granitic texture were seen and also a few pebbles or bowlders which might have been derived from the greenstones of the Orca group. The matrix is commonly a black argillaceous material, and most of the conglomerate was probably derived by erosion from the slates and graywackes of the Valdez group. The bedding of the finer gritty beds of the conglomerate can in general be easily determined, but the coarser conglomerates are massive and at many places show no distinguishable bedding planes. Indeed, in these large bowlders and angular fragments, many of which are several feet in diameter, and in their intermingled coarse and fine material, which in many places shows no assortment through a considerable thickness of beds, the conglomerates resemble strikingly an indurated glacial till or tillite. No striated rocks were found in the deposits, and the large amount of finer, well-assorted beds associated with the conglomerates calls for caution in assigning to these beds a glacial origin. In the Yakutat Bay region, Blackwelder ${ }^{1}$ has described angular bowlders, interspersed through shales and slates, which he believes to have been dropped by glacial ice, but there is now no proof that the conglomerates of the Ellamar district are of glacial origin.

UPPER SLATES AND GRAXWACKES.

That part of Bligh Island that lies southwest of Busby and Cloudman bays is composed of slates and graywackes. Lithologically the rocks are much like those of the Valdez group and the lower slates and graywackes of the Orca group. Structurally these beds are different from those already described, for instead of being generally uptilted at steep angles they lie is a series of low folds and look younger than any of the other slates and graywackes of the district (Pl. IX, $A$ ). The only rocks that outcrop in contact with them are the greenstones on the northeast side of Bligh Island, and this contact, though nowhere exposed, is believed to mark a fault. There is therefore no direct structural evidence of the áge of this series of slates and graywackes, but as it is less metamorphosed than the con-

1 Blackwelder, Eliot, Jour. Geology, vol: 15, pp. 11-14, 1907. 
glomerates it is provisionally placed above them and is thought to comprise the youngest rocks of the Orca group exposed within the Ellamar district.

\section{STRUCTURE.}

In discussing the structure of this group it may be well to review here briefly the evidence on which the group was originally separated from the Valdez group. The criteria first used by Schrader and later by Grant and Higgins ${ }^{2}$ for the separation of the Orca rocks from the Valdez are (1) the lesser amount of metamorphism of the Orca, (2) the presence in it of extensive greenstones and conglomerates, and (3) the geographic position of the Orca to the southward of the Valdez rocks, apparently above them stratigraphically. These distinctions no doubt hold for the Prince William Sound region as a whole, but in individual districts, as in that with which this report is concerned, extensive faulting accompanied by local metamorphism has taken place, and certain areas of slates and graywackes which are probably of Orca age have been more intensely metamorphosed than other neighboring areas of the older Valdez rocks. For these reasons the placing of some areas of the slates and graywackes in one group or the other is open to question, and more detailed work will be necessary before they can finally be assigned to a place in the geologic column.

Grant ${ }^{2}$. has stated definitely that the Orca group lies unconformably on the Valdez, though he does not cite the localities at which this relationship could be observed. In many places in this district, the contact between the Orca and Valdez is now known to be a fault contact and not one of deposition. However, though the unconformability of the two groups is accepted, there are in Galena Bay certain slates and graywackes which Grant has mapped with the Valdez group and which certainly lie conformably below the greenstones of the Orca group. This has necessitated changing the southern boundary of the Valdez as mapped by Grant and throwing a part of his Valdez group into the lower part of the Orca. Certain other slates and graywackes in the vicinity of Graveyard Point, the relations of which are not clear, might by reason of their great metamorphism be considered as belonging in the Valdez group, but in the absence of definite evidence of their age and because of their intimate association with the greenstones they have been tentatively left in the Orca group, where they were placed by Grant. No hesitancy was felt'in including the greenstones in the Orca group, and their conformable superposition on the lower series of slates and graywackes is believed to have been established. The conglomerate also lies 
conformably upon the greenstones. After noting the positions of the conglomerate north of Galena Bay and its situation near the contact with the Valdez, Grant decided that it is the basal part of the Orca group, and that it is succeeded above by the greenstones, which were followed by the other divisions. The writers, however, found what they believe to be conclusive evidence that the greenstones lie upon slates and graywackes and were followed above by the conglomerate. This conclusion was based on the relations of the greenstones to the interpolated slate beds and on the difference in appearance of the top from the bottom of the lava flows. If this interpretation is correct it necessitates reversing the succession as determined by Grant, and placing his so-called basal conglomerate many thousand feet up in the Orca group.

The thickness of the Orca group is unknown, and probably differs greatly in different localities. The greenstones are several thousand feet thick near Ellamar, but at other places are not present at all. The conglomerate at Rocky Point also appears to be at least 3,000 feet thick but is believed to be more extensively developed here than in many other parts of Prince William Sound. Measurements of the lower slate and the slate-graywacke series are of doubtful value, for they may be repeated by undetected faults. All the divisions of the Orca group, as well as the older Valdez rocks, have been extensively faulted, and the displacement of many of the faults. can not be measured.

AGE.

No diagnostic fossils have been obtained in the Orca rocks of the Ellamar district, and a positive statement as to the age of the group can not now be made. A part of the confusion which exists with regard to the distribution and age of the group arises from the fact that the slates and graywackes of the Orca and Valdez groups are so similar in appearance and have been so much involved with one another by deformation and faulting that it is impossible to separate them except by detailed and painstaking work, and detailed work has not yet been done throughout most of the area in which these rocks occur. In the summer of 1913 B. L. Johnson collected, at several localities in the Port Wells district, fossils that are probably Mesozoic, though the rocks in which they were found had previously been mapped with the Valdez group. These fossiliferous rocks may perhaps be correlated with the Orca group, which is believed to be of early Mesozoic age. The only identifiable fossil so far collected from the Ellamar district is a worm tube (Terebellina palachei Ulrich) obtained by Grant and Higgins ${ }^{1}$ at a point just north of the entrance to Galena Bay, and it has little value in deter-

1 Grant, U.S., and Higgins, D. F., Reconnaissance of the geology and mineral resources of Prince William Sound, Alaska: U. S. Geol. Survey Bull. 443, p. 32, 1910. 
mining the age of the rocks in which it occurs. Until definitely identifiable fossils are collected from unquestioned Orca rocks, some uncertainty as to their age must exist.

\section{QUATERNARY DEPOSITS.}

GLACIATION.

After the deposition of the Orca rocks there was a long period of time during which the sediments were consolidated and then folded and faulted. The stresses that brought about the metamorphism were probably mountain-building forces operated continuously until the mountains had reached their present height. The slow process of mountain making may even now be in progress. Whether the Orca rocks of this district were ever covered by later sediments that have since been removed we do not know, but on other parts of the Pacific coast region later beds were laid down during Eocene time and still remain.

The last important geologic event in this region was the advance of the great ice sheet, which has had a far-reaching effect in shaping the surface to its present form. Changes in climate favored a rapid accumulation of ice in the mountains, and glaciers were formed, at first only on the high mountains, but as they gradually increased in size, they pushed their way down the many valleys to the sea. With continued growth they coalesced in the area now occupied by Prince William Sound and formed a great glacier, which pushed far to the south of the Ellamar district. The outer limits reached by this glacier are not known, but it certainly reached Montague and Hinchinbrook islands and probably extended around and beyond them some distance out to sea. Thus the basin of the sound was deeply filled with ice. Near Ellamar the surface of the glacier was about 3,000 feet above sea level, for Ellamar Mountain shows glacial scouring and grooving nearly to its top. The grooves were not made by a local glacier, for Ellamar Mountain never supported a glacier of its own, but by an ice stream which came from the north, almost if not completely submerging it. Copper Mountain also shows glacial erosion to a height of at least 3,000 feet. Erosion by this ice sheet was sufficiently strong to shape the mountains up to the highest level to which the ice reached, and its effects on the lowlands were profound. Fragments of rock embedded in the bottom of the glacier and pressed down by the weight of several thousand feet of moving ice ground away the glacial bed and removed many obstacles in the path of the glacier and carved out broad troughlike valleys, many of which were excavated far below sea level. Indeed, most of the bays and channels of the Prince William Sound region are probably due largely to glacial scour. 
When the ice reached its greatest extent, and lobes of it were pushed into the sea, the amount of deepening of the ice bed by glacial erosion was more or less independent of the level of the sea beyond the edge of the ice, so that with the gradual retreat of the glaciers the encroaching sea flooded those parts of the glacier bed which had been eroded below sea level and formed the many irregular bays and channels of the present coast line. Other portions of the rock floor remained at different elevations above the sea. The broad, low pass between Boulder and Galena bays is an example of a glacial trough which was scoured down almost but not quite to sea level. If ice erosion there had been somewhat longer continued this trough would have been cut below sea level, and the peninsula between Galena Bay and Tatitlek Narrows would have been an island. The low divide between Cloudman and West bays on Bligh Island and the lowland at the east entrance of Landlocked Bay are portions of the glacier bed that were deepened nearly to sea level. Landlocked, Boulder, Galena, and West bays and Tatitlek Narrows were excavated by the ice below sea level and were flooded by the sea when the ice withdrew.

It is difficult to reconstruct in mind the drainage system of this region as it was before the period of glaciation, for the ice has done much to destroy the continuity of the former stream valleys. It is believed, however, 'that the principal valleys, bays, and channels of to-day were the valleys of the preglacial streams, and that the glaciers, although they profoundly changed the shape of their basins and in many places formed new valleys, have in the main only widened and deepened the valleys of preexisting streams.

Although there are now no glaciers in the Ellamar district a very slight change in the climate might again cause glaciers to form there. An active glacier is said to exist at the head of the stream which flows into Galena Bay from the northeast, and a few miles northwest of the district Columbia and Shoup glaciers extend to tidewater and discharge into the sea. The higher parts of the Chugach Range are therefore still in the glacial epoch, which has there continued down to the present time.

\section{UNCONSOLIDATED DEPOSITS.}

The unconsolidated deposits of the Ellamar district consist of the glacial material left by the ice, the postglacial talus, and the deposits of the present streams. When one considers that the whole district was heavily glaciated at a time which, considered geologically, was not long ago, the quantity of morainal material left by the ice is surprisingly small, and on the accompanying geologic map (Pl. II, in pocket) the unconsolidated deposits have not been mapped. This district was essentially an area of glacial erosion, and most of the materials removed by the ice were deposited by it farther south, in 
the sea. At some places, however, there are accumulations of glacial till, left by the ice during its retreat. The till occurs especially in the lowland areas of slight relief. In the more rugged mountains it was either never deposited or has since been removed by erosion. The areas of till in general are heavily covered by vegetation, so that good exposures are scarce. The best exposures are found at points on the beach where wave cutting is active, as on the southeast side of Bidarka Point, where cliffs show 30 feet or more of bluish clay that incloses bowlders and fragments of a large variety of rocks. A mantle of till covers the surface of the underlying rocks on the lowlands north of Graveyard Point near Tatitlek and at many other places.

Talus accumulations are insignificant in the area here considered. The comparatively short time which has elapsed since the mountains were freed from glacial ice has been insufficient for much talus to form, except at the base of high, steep cliffs, and even in those places the quantity is surprisingly small.

The gravels of the present streams are of small surface extent and of no great depth. Erosion by streams since the retreat of the glacier uncovered this district has been slight, and only a few streams have been able to cut well-defined channels into the rock. The larger streams have naturally been able to erode more vigorously, but the steepness of their gradients has prevented the accumulation of extensive gravel deposits along their courses, and the amount of material handled by them can best be estimated by the size of their delta deposits. Thus Bottle Creek, although its channel is remarkably free from gravels, has built out a rather extensive delta at the east end of Galena Bay. The head of Landlocked Bay is also shallow, having received the sediments brought down by two large creeks. Most of the streams, however, are small and empty into tidewater on exposed portions of the coast, at places where the action of waves and currents has carried away the stream-brought materials as fast as they were deposited.

\section{IGNEOUS ROCKS.}

It has already been stated that dikes of igneous intrusive rocks cut the formations in the district. These dikes cut rocks of the Valdez group, and also those formations of the Orca group that lie below the greenstones. The greenstones of the Orca group consist primarily of lava flows but include also certain coarser-grained rocks, which were probably intrusive. The lower part of the conglomerate is closely associated with the lavas, but no dikes were seen in either the conglomerate or the upper series of slate and graywackes 
of the Orca group. The dikes that cut the Valdez group and the lower beds of the Orca group are, of course, younger than the formations into which they were intruded. Thin sections of the various types of igneous rocks were studied by J. B. Mertie, jr., who reports that all the rocks examined, though they show different characters at different localities, may have been derived from the same magma. It is therefore believed that the numerous dikes of the region were intruded in the same general period during which the lava flows of the Orca group were extruded. From the north side of upper Galena Bay two dike rocks were collected, which present certain mineralogic similarities, though they have a different megascopic appearance. One, an altered basalt, has a hypocrystalline texture and contains some phenocrysts of labradorite, which has in part been altered to sericite and calcite. The groundmass, a part of which also is com.* posed of labradorite, contains basaltic glass, most of it altered to calcite, and some magnetite. The other dike is a fresh, unaltered diabase of ophitic fabric. It consists of labradorite, augite, and magnetite. The quartz diabase that forms some islands in Tatitlek Narrows, south of Tatitlek village, has been mapped with the greenstones of the Orca group, though it is of coarser texture than that seen elsewhere in the greenstones. This intrusive mass may represent one of the vents from which the greenstone lavas were extruded. The rock is ophitic and is composed of comparatively fresh augite, labradorite considerably altered to chloritic material, ilmenite with lamellar twinning, quartz, and minor quantities of magnetite and apatite.

The greenstones of the Orca group range in megascopic character from aphanitic ellipsoidal flows to more massive diabases and the sheared equivalents of both of these types. Both types include amygdaloidal rocks. The basalts are in many places largely composed of volcanic glass containing small crystals of labradorite. The groundmass and the phenocrysts are very generally altered to sericite and chloritic material and contain iron oxides and secondary calcite, with some titanite, the calcite forming the amygdules in many specimens. The diabases are in composition much like the basalts, except in their freedom from volcanic glass. The principal rockforming minerals are labradorite and augite, iron oxides and leucoxene appearing in subordinate amounts. The amygdules are usually filled with calcite and chlorite, and some contain also epidote and quartz. The sheared equivalents of the diabase show broken labradorite crystals in a groundmass of chloritic material, together with quartz and other secondary products and minor quantities of iron hydroxides and some zoisite. 


\section{MINERAI, RESOURCES。}

By B. L. Johnson.

\section{METALS PRESENT.}

The mineral resources of the Prince William Sound region comprise deposits of copper, gold, silver, zinc, iron, and antimony. Copper, gold, and silver are the only metals now recovered from the ores of this region. The silver is obtained from both gold and copper ores. A part of the gold produced is obtained from the copper ores, but most of it comes from gold quartz mines.

\section{GEOGRAPHIC DISTRIBUTION OF THE DEPOSITS.}

PRINCE WILLIAM SOUND MINERAL BELTS.

The entire Prince William Sound region may be subdivided into more or less isolated districts characterized by the preponderance in a given area as a whole of either gold or copper deposits. A grouping of these districts into two broad concentric belts, one of the gold districts and the other of the copper districts, is quite noticeable. In general, the gold districts lie in a broad belt, concave to the south, bordering the sound, and lying to the landward of and partly surrounding the copper belt. These gold districts are, reckoning west to east, the eastern shore of Kenai Peninsula, Port Wells, Valdez, Tiekel and Tasnuna, McKinley Lake, and Bremner River. The first three of these districts border the sound from Cape Junken to Unakwik Inlet and from Columbia Glacier to Valdez. The goldbearing belt then continues eastward from the Valdez district toward Tiekel, Tasnuna, and Bremner River districts. The McKinley Lake district lies southeast of the copper district around Cordova.

The copper districts lie south of the gold deposits, in a belt rounding the inner shore of the sound and concave southward. This curved belt as now developed consists of a number of detached copper districts separated by stretches in which copper deposits are not known to exist. At the southwest end of this belt are the copper deposits of Latouche, Knight, Bainbridge, and Elrington islands; at the crest are those of Glacier Island and the mainland to the northwest, including Unakwik Inlet, Wells, and Long bays; and along the eastern arm of the belt are the copper deposits of the Valdez district, the Ellamar district, and Ports Fidalgo and Gravina, Sheep and Orca bays, and Orca Inlet.

RELATION OF ELLAMAR DISTRIOT TO PRINCE WILLIAM SOUND MINERAL BELTS.

The Ellamar district, as defined in this report, is a small area in the northeast part of Prince William Sound, within the copper belt outlined above. Descriptions of three properties on Port Fidalgo 
are included under the detailed descriptions of mines and prospects (pp. 112-122). No geologic work has been done in that section, but it was thought best to publish these descriptions and to include them in this report. They are not considered in the general discussion of the mineral resources of the Ellamar district, which is treated in this report as a distinct unit. The district is well known as a copper district-an integral part of the Prince William Sound copper belt. The metal production is derived entirely from copper lodes and consists principally of copper, although considerable gold and silver are also obtained from the ores. A few gold quartz veins have been located, but they have never become producers.

The area considered in this report lies entirely within the Valdez recording district of the third judicial division of the Territory of Alaska. The recording office of the district is at Valdez.

\section{DISTRIBUTION OF MINERAL DEPOSITS WITHIN THE ELLAMAR DISTRICT.}

The mineralized portion of the Ellamar district has a northwest trend, paralleling the dominant structural features of the district. The copper deposits thus far found all lie within the area bounded by Port Fidalgo, Tatitlek Narrows, Galena Bay, and a line connecting the heads of Galena and Landlocked bays. Within this area there is a marked grouping of the copper deposits on the flanks of Copper Mountain and along the ridge between Vesuvius Valley and the gap between Galena and Boulder bays. The Ellamar mine, on Virgin Bay, occupies an isolated position, apart from the other known copper deposits. Deposits of gold-bearing quartz have been found on Banzer and Gladhaugh creeks and on the east side of Bligh Island. The gold quartz prospects are scattered and are of little value except as they show a greater extent of the area subjected to mineralization than would be indicated by the distribution of the copper deposits.

The known vertical range of the mineralization is over 3,000 feet, extending from nearly 600 feet below sea level at the Ellamar mine to an elevation of about 2,500 feet above sea level on Copper Mountain.

Copper deposits are distributed throughout the vertical range of mineralization. Deposits of gold-bearing quartz have only been. reported at elevations of less than 1,000 feet. Quartz veins, more or less mineralized, are found, however, at much greater elevations.

The productive mines of the district are copper mines and are all located at or near sea level on Virgin and Landlocked bays. The producing mines in 1912 were the Ellamar mine, at Ellamar, on Virgin Bay, and the mines of the Threeman Mining Co. and the Landlock Bay Copper Mining Co., on Landlocked Bay. (See Pl. I, in pocket.) 


\section{PRODUCTION.}

The mineral production of the Ellamar district is not given in this report, as it is not the policy of the Survey to publish the production of a district where the figures would make public the production of individual properties. The annual and total production of the Ellamar district is and has always been principally that of the Ellamar mine, although other properties have at different times made single shipments and in 1912 the Threeman Mining Co. shipped regularly over a period of several months. Historical data regarding the shipments from the various properties are given on page 14 .

\section{LITERATURE.}

Numerous references to the Prince William Sound ore deposits appear in geologic and mining literature. As but few actual investigations have been made of these deposits, most of these references are based on the published results of earlier investigators in the Prince William Sound region. Recent work, more detailed than that of the previous investigators, has resulted in conclusions regarding the occurrence and genesis of these deposits differing in many respects from the views formerly held. These conclusions are given in detail elsewhere in this report, and are followed by detailed descriptions of characteristic deposits. To render easy a comparison of the views of the earlier investigators and those resulting from the work done in 1912 and 1913, abstracts are given here of the published articles which contain original references to the Prince William Sound copper deposits or to those of the Ellamar district. The articles are arranged chronologically.

1899. Schrader, F. C., Report on Prince William Sound and the Copper River region, in "Maps and descriptions of routes of exploration in Alaska in 1898, with gen. eral information concerning the territory": U. S. Geol. Survey special publication, p. 59.

Contains a very brief description of the Alaska Commercial Co.'s prospect on Landlocked Bay and the Gladhaugh Bay mine, now known as the Ellamar mine, on Virgin Bay. States that the ore of the Alaska Commercial Co., "as observed by Mr. J. E. Spurr, occupies a shear zone in the green amphibolite schist and consists principally of copper pyrites and bornite." The Ellamar ore body is referred to as "a vein or deposit mostly of iron and copper pyrites" and the suggestion made that "the contact of an igneous rock (diabase) with the country rock here seems to have something to do with the ore deposit."

1900. Schrader, F. C., A reconnaissance of part of Prince William Sound and the Copper River district, Alaska, in 1898: U. S. Geol. Survey Twentiet Ann. Rept., pt. 7, pp. 417-423.

Brief descriptions are given of the Alaska Commercial Co.'s prospect on Landlocked Bay, the Ripstein ledge on Boulder Bay, and the Gladhaugh Bay mine (Ellamar mine). At the Alaska Commercial Co.'s prospect the ore is said to consist "principally of copper pyrites and bornite." The croppings were "visited by Mr.' Spurr in October, who found the deposit to occupy a 
shear zone in the Copper Mountain greenstone or amphibolite schist. * * * The ore, which is sometimes brecciated with country rock, consists of chalcopyrite, some bornite, marcasite, yellow iron pyrites, with some quartz and some specularite."

The Ripstein ledge "also occurs in the green amphibolite schist, which forms the footwall on the south, while the hanging wall on the north seems to be a greenish quartzite, probably an altered phase of the schist." The ledge "consists for the most part of soft light-grayish pyritiferous copper ore, usually fine grained, and which seems to contain much marcasite. There is also present a considerable amount of purple copper ore, with a considerable admixture of quartz."

The essential features of the Ellamar mine are given as follows: The ore body is "a vein or deposit * * * consisting mostly of iron and copper pyrites. * * The contact of an igneous dike of olivine diabase with the country rock here seems to have something to do with mineralization of the ore deposit. The country rock in which it occurs is a gray arkose of medium grain. The ore deposit or vein trends with the rock, or nearly east and west, and seems to dip steeply to the north. * * * The ore $* * *$ consists largely of chalcopyrite and gray copper ore, with some bornite, producing the peacock variety; some epidote is present. There is also present an apparently large amount of white iron pyrites or marcasite."

1901. Schrader, F. C., and Spencer, A. C., The geology and mineral resources of a portion of the Copper River district, Alaska: U. S. Geol. Survey special publication, pp. 88-89.

"In Prince William Sound the copper occurs in two ways: First, in fissure veins; second, in mineralized zones, which seem to be nearly or quite parallel to the bedding of the heterogeneous strata composing the Orca formation. The deposits of Copper Mountain, in Landlocked Bay, are of the fissure-vein type *** and other instances of fissure veins were observed *** south of Orca in the vicinity of Fleming Spit. In both of these localities the country rock is greenstone diabase or basalt, apparently occurring in large masses. All of the other occurrences, so far as they are at present known, are impregnations of zones of more or less crushed country rock by sulphides of copper and iron. In most instances the ore occurs in the interbedded flows of greenstone, $* * *$ but it is also found in the arkose sandistones and in the shales. *** The association of the ores with the greenstone is very general, for even when they lie in sedimentary rocks the igneous rock is never very far distant. It may be suggested that the origin of the copper is to be sought in the flows or intrusions of basalt or diabase, from which it has been concentrated by means of circulating waters."

The essential features of the Gladhaugh (Ellamar) mine are given as follows:

"The Gladhaugh vein is a practically solid mass of iron and copper pyrites. It has a width of more than 125 feet where exposed, and extends along the strike for a known distance of more than 300 feet. The north wall of the vein, where it comes in contact with the shale, has a course N. $45^{\circ} \mathrm{W}$. and the dip is $30^{\circ}$ toward the north; but possibly the general dip is considerably steeper, since the footwall is known to have a much greater pitch.

"Locally there are some small inclusions of country rock within the vein, and occasional lenses of calcite are found, with a small amount of bornite."

1.904. Emerson, B. K., General geology: Alaska, vol. 4, pp. 24-25, Harriman Alaska Expedition.

In a brief description of the Alaska Commercial Co.'s prospect on Landlocked Bay the writer states: "The deposit of copper ore is a mass of quartz, with chalcopyrite, pyrrhotite, and small amounts of galena and sphalerite, 
occupying a shear zone in a rock of serpentinous character. Thin sections of this rock showed a mass of fibrous serpentine in which are embedded shattered crystals of perfectly fresh labradorite and abundant augite raveled out on the edges to colorless hornblende and serpentine. There are still traces of ophitic structure, and the rock is evidently a sheared and partly serpentinized diabase."

The Ellamar mine is referred to as follows:

"At Virgin Bay we found the rocks at the shore for a great thickness impregnated with pyrite and chalcopyrite, forming in some places solid compact ore, associated with a dark quartzite and with beds of fine-grained micaceous sandstone and magnesian limestone. Just west of the mine the sandstone is cut by a thick diabase dike."

1904. Palache, Charles, Notes on the minerals collected: Alaska, vol. 4, pp. 94-96, Harriman Alaska Expedition.

Notes the occurrence of chalcopyrite, galena, pyrite, pyrrhotite, and sphalerite in Landlocked Bay, and chalcopyrite, pyrite, and sphalerite in Virgin Bay.

1906. Brewer, W. M., Some observations relative to the occurrence of deposits of copper ore on Vancouver Island and other portions of the Pacific coast: Canadian Min. Inst. Jour., vol. 9, pp. 44-45.

The Ellamar mine is placed in a class in which chalcopyrite ore occurs at the contact of crystalline limestone, slate or schist, and basic igneous rocks.

1906. Grant, U. S., Copper and other mineral resources of Prince William Sound: U. S. Geol. Survey Bull. 284, pp. 78-87.

This has a much more complete discussion of the mineral resources of the Prince William Sound region, including the Ellamar district, than that contained in any of the preceding references.

"The chief ore of the district is chalcopyrite ***. This is very generally associated with pyrrhotite $*^{* *}$ and to a less extent with pyrite *** and marcasite; these iron sulphides probably carry small amounts of copper. Chalcocite was noted in one place, near Orca. Secondary carbonate of copper occurs as a green surface stain; this is usually malachite and rarely azurite. The alteration of the original copper sulphides to form these carbonates is a superficial phenomenon, and they occur at or very near the surface or along cracks within a few feet of the surface. Occasionally small flakes of native copper are found in the upper parts of the veins; this is evidently also a secondary mineral. Oxidation of the iron sulphides has given rise to the usual rusty-brown capping (iron hat) to the veins, but this oxidation, except along cracks, extends commonly only a few inches from the surface.

"The copper veins now being prospected are mainly along shear zones. These usually occur in the greenstones or in their immediate vicinity. Not uncommonly a shear zone agrees closely with the contact between greenstone and a layer of slate or graywacke. This association of ore deposits with the greenstones is so pronounced that these igneous rocks can be regarded as the original sources of the copper. The shear zones vary in width from a few inches to several feet-in one case a width of 8 feet being reported. While in a few cases there evidently were along the shear zones open cavities which have been filled with metallic sulphides and quartz, the general conditions indicate that the ore minerals have replaced the country rock, rather than that they were deposited in such cavities.

"Most of the prospects show shear zones made up of two rather distinct layers. One is a layer of nearly solid sulphides (chalcopyrite, pyrrhotite, and pyrite), or of these sulphides mixed with some quartz and country rock; 
the other layer consists of sheared rock, sometimes silicified, with disseminated ore minerals. The sulphide layer may be on one wall of the shear zone, or it may be near the center of the zone with a layer of disseminated ore on either side. This sulphide layer varies considerably in composition in the different prospects, being in some almost solid pyrrhotite and in others chalcopyrite with little pyrrhotite; the variation in composition in any individual sulphide layer is not so marked. In thickness these sulphide layers vary from an inch to, in one case, 8 feet; and any given layer varies in width along both the strike and the dip. Some of the sulphide layers pinch out entirely along the strike and then reappear; thus bodies of ore of lensshaped cross section occur whose length is several times their greatest thickness. These lenses may also pitch along the direction of the strike. Individual veins have been traced continuously for half a mile or more, and further prospecting will undoubtedly show that some of them can be followed for several miles. * * * The strikes of the veins vary considerably, but frequently agree rather closely with that of the country róck. The dips of the veins are commonly high, usually between $60^{\circ}$ and $90^{\circ}$.

"In addition to the shear zones there are some sharply defined veins of small size, and on Knight Island prospecting has been done in a rather massive greenstone which contains disseminated chalcopyrite and pyrrhotite. The two producing mines of the district are in deposits which differ somewhat from the simple shear zones above described.

"The ore deposits now known occur, with very few exceptions, in the rocks of the Orca series."

Descriptions are given of the following properties within the Ellamar district: the Gladhaugh (Ellamar) mine, and prospects on Galena, Boulder, and Landlocked bays.

Regarding occurrence and genesis of ore at the Gladhaugh mine, he says:

"The direction of the long axis (of the ore body) is approximately N. $35^{\circ} \mathrm{W}$. The dip of the walls varies from $80^{\circ}$ to $90^{\circ} \mathrm{NE}$. and there is a pitch of the ore body of about $35^{\circ} \mathrm{E}$. The ore body consists of chalcopyrite, pyrite, pyrrhotite, and country rock. Frequently the rock is lacking and then the ore body is practically solid sulphides, with chalcopyrite in marked amount. The best ore, i. e., that in which the proportion of chalcopyrite is highest, is in general confined to a poorly defined ore shoot which forms the middle of the footwall half of the ore body. The country rock is soft black slate, with a few bands of graywacke and black limestone. The strike of the rocks is in general parallel to that of the ore body. *** The black slate is much fissured and crushed and the fragments are commonly slickensided. The ore is in the main massive and not fractured, although there are some small cracks which have been filled with calcite."

In Galena Bay mention is made of shear zones carrying "layers of sulphides" in Vesuvius Valley. Reference is made to the long tunnel which "runs along a clay selvage, which is from an inch to a foot in thickness. Pyrite, pyrrhotite, and chalcopyrite in stringers occur in and near this selvage, and small amounts of these sulphides are disseminated in the wall rock. The tunnel is mainly in greenstone, but a narrow band of black slate is commonly seen along the footwall of the vein." $* * *$ This tunnel is being driven to reach a "shear zone, which is 40 feet wide and contains considerable unsheared rock and locally carries bands and scattered grains of sulphides."

"Several weins of the usual type have been discovered on both the east and west shores" of Boulder Bay.

On the shores of Landlocked Bay "and running up on the south and east flanks of Copper Mountain are a number of rather well exposed shear zones, mainly in the greenstones. Many of these carry copper and iron sulphides." 
The Alaska Commercial Co.'s prospect "is a shear zone 4 feet in thickness. The strike is $\mathrm{N} .68^{\circ} \mathrm{E}$. and the dip $75^{\circ}$ to $80^{\circ} \mathrm{N}$. In this zone is a layer of sulphides (pyrrhotite and chalcopyrite) 2 to 8 inches in thickness."

On the property of the Threeman Mining Co. "three tunnels *** have been run in along a shear zone containing a layer of fairly solid sulphides. This layer varies from an inch to 2 feet in thickness and has on its hangingwall side some chalcopyrite disseminated in the sheared country rock." Other prospects in the immediate vicinity are noted "which show layers of solid sulphides (chalcopyrite and pyrrhotite) up to 3 feet in thickness.".

Three quartz veins, "which were reported to show considerable values in gold were examined-one on the north flank of Copper Mountain, one in the eastern part of Glacier Island, and one on the point between Landlocked Bay and Port Fidalgo. Assays have been made from two of these veins; one assay was from the decomposed upper part and the other from the solid vein about 15 feet below the surface. The assay reports show only traces of gold and a fraction of an ounce of silver per ton." These assays show the quartz veins of the Ellamar district to be at least gold bearing.

"In the copper veins, gold and silver are almost invariably present in small amounts, and commonly gold is found in the copper ores $* * *$ in amounts running from $\$ 1$ to $\$ 5$ per ton. The silver content of these copper veins is commonly less than $\$ 1$ per ton.

"Two mines on Prince William Sound have demonstrated that copper ore of good grade occurs in this district and that it can be produced at a profit. ***.

"No considerable secondary concentration of ores exists. The ores of possible commercial importance have all the characteristics of primary deposits and are a phase of a general sulphide deposition along certain channels or zones. In general there is no reason to expect that stringers of ore on the surface will develop in depth to payable veins or that veins of considerable width at the surface will continue with unvaried dimensions and richness to great depths. On the contrary, it is known that ore bodies pinch out in individual cases, and, on the whole, irregularity of form is to be expected. Developments of prospects should be confined to the following of ore. Running long crosscuts to catch stringers or veins in depth is bad practice, since experience has shown that the continuation of the deposits is by no means assured."

1907. Brooks, A. H., The mining industry in 1906: U. S. Geol. Survey Bull. 314, pp. $25,27$.

"In Prince William Sound the copper deposits are intimately associated with greenstones and greenstone schists, probably of Mesozoic age, which are relatively little altered. Granitic intrusions are present in this province, but the ore bodies are not known to have any relation to them."

"As Grant has shown, the ore bodies, chiefly chalcopyrite, occur as a rule along shear zones in the greenstone."

1907. Grant, U. S., Copper prospects of Prince William Sound, Alaska: Eng. and Min. Jour., vol. 83, p. 229.

The data given are taken from United States Geological Survey Bulletin 284.

1907. Graton, L. C., Copper: U. S. Geol. Survey Mineral Resources, 1906, p. 385.

Regarding the Prince William Sound region the statement is made that the ore is "chalcopyrite more or less disseminated through metamorphosed sedimentary rocks. *** It carries a little silver, moderate silica, and rather low iron and alumina." 
1907. Weed, W. H., The copper mines of the world, pp. 257-258, Hill Publishing Co., New York and London.

The data presented are largely taken from United States Geological Survey reports. The Prince William Sound ores are described as "sulphides, chiefly chalcopyrite, with associated pyrrhotite and pyrite in a gangue of quartz and country rock. These ores occur in lenticular ore bodies in shear yones whose direction coincides with that of the contact between greenstone and layers of slate or graywacke, or to the foliation of the rocks."

The Ellamar ore body "is a lens. *** The ore varies from solid sulphides to impregnated country rock. It is inclosed in a crushed and soft black slate with some layers of graywacke and black limestone."

The Copper Mountain deposits are "in shear zones in greenstone and slates."

1908. Brooks, A. H., The distribution of mineral resources in Alaska: U. S. Geol. Survey Bull. 345, p. 27.

"In the Prince William Sound region $* * *$ the geographic distribution and the genetic relation of the ore bodies are still obscure.".

1908. Moffit, F. H., Notes on copper prospects of Prince William Sound: U. S. Geol. Survey Bull. 345, pp. 176-178.

The description of the ore deposits is apparently an abstract of Grant's views as given in United States Geological Survey Bulletin 284.

"The copper ores are chiefly chalcopyrite, generally associated with pyrrhotite and less commonly with pyrite and marcasite. It occurs in many places in shear zones in greenstone, and this association of copper ore with greenstone is so pronounced that the copper is believed to be derived from the greenstones."

1909. Grant, U. S., and Higgins, D. F., jr., Copper mining and prospecting on Prince William Sound: U. S. Geol. Survey Bull. 379, pp. 93-95.

Includes descriptions of several properties in Ellamar district.

The Reynolds Alaska Development Co.'s workings on Boulder Bay are "driven through interbedded greenstones, slates, and graywackes. * * * A few veins of chalcopyrite were encountered. *** Greenstone having locally small quantities of disseminated chalcopyrite" was found in an upper tunnel. "Veins 2 to 3 inches wide also occur, and on the face a foot of ore was present."

The Fielder \& Hemple prospect uncovered "surface showings of chalcopyrite in sheared greenstone."

The earlier shipments of the Ellamar mine "were derived from a rather poorly defined ore shoot in which the chalcopyrite was more abundant than the pyrite and pyrrhotite and the later shipments evidently came, in part at least, from outside this ore shoot. *** The ore body is a lens-shaped mass of these copper and iron sulphides."

At the Standard Copper Mines Co. three ore zones are mentioned. "These zones are schistose areas in the greenstone of Copper Mountain and they carry lens-shaped bodies of ore."

The Threeman Mining Co.'s veins on Landlocked Bay "are in greenstone, graywacke, and slate, and consist of schistose shear zones carrying chalcopyrite and pyrrhotite. These sulphides occur to some extent in solid, more or less lens-shaped bodies within the schistose rock. The sulphide bodies, which are in places composed very largely of chalcopyrite, vary from a few inches to a few feet in thickness."

At the Hemple prospect on Landlocked Bay one tunnel has been driven "the first 40 feet of which is in broken greenstone with numerous small 
veins of chalcopyrite. A second tunnel *** crosscuts three orebearing zones. *** Extending 1,200 feet west from this upper tunnel is a series of 15 to 20 small strippings and pits on a schistose zone in greenstone."

1909. Stevens, Blamey, Prince William Sound; its geology and mineralogy: Northwest Min. Jour., vol. 8, pp. 3-6.

Notes that the larger mines are not in the greenstone but in the slates and sandstones in the vicinity of the greenstones.

States that the greenstone is composed of successive lava flows at the surface. Dikes of diabase are to be found in the rocks underlying the greenstone and also in the greenstone itself in a few cases. Smaller mines are said to be chiefly in the greenstone, whereas the larger ones are found in the rocks between the diabase dikes and the greenstone flows. Concludes that both rocks have come from the same magma; that the smaller deposits have been formed from the greenstone after volcanic agencies had brought it to the surface; and that the larger deposits have been formed from aqueous solutions forced out from the more confined magma in the dikes. "The deepseated deposits *** are large lenses and zones occurring in the slates and arkose rocks. $* * *$ They were evidently formed by replacement, the original stratification of the rocks being often reproduced in the matrix. * * * The minerals deposited are principally pyrites and chalcopyrite; there is some pyrrhotite but it forms a very small percentage of the total minerals. *** The deposits are found quite distant from the dikes from which they are supposed to be derived." The order of deposition is given as (1) chalcopyrite, (2) pyrrhotite, (3) pyrite. Notes a secondary chalcopyrite enrichment at Ellamar, "not due to any recent action." "The deposits in the greenstone are typically different from the deep-seated ones, the main distinction being in the almost total absence of chalcopyrite."

"In and around Copper Mountain the mineral occurs in narrow veins which are usually very crooked. Chalcopyrite seems to be the first deposited mineral and forms the nucleus of a shoot more or less surrounded by pyrrhotite, which extends intil the vein pinches out to nothing. The chalcopyrite is often very free from pyrrhotite."

"The ore of the greenstone around the bays in the vicinity of Landlock are ores formed near the surface from volcanic rock."

Notes a reported increase in abundance of pyrite and a decrease in pyrrhotite as depth of ore formation increases.

"There is practically no surface decomposition and no surface enrichment. The ore may in every case be expected to be of the same character in depth as on the very surface of the ground."

1910. Grant, U. S., Copper deposits of Prince William Sound, Alaska: Min. and Sci. Press, vol. 100, pp. 63-64.

Most of the ore deposits are stated to occur in or close to greenstones of Orca age, "and where these rocks occur prospects are common. * * * Granites, intrusive into both the Valdez and Orca rocks, occur but bear no relation to the ore bodies." The ore minerals are stated to be chalcopyrite, pyrrhotite, pyrite, chalcocite, native copper, malachite, and azurite.

"The copper deposits occur in zones along which there has been fracturing and usually shèring of the country rock." The "sheas zones occur mainly in the greenstones and in some places follow closely the contact of the greenstones with the adjoining sediments. * * Chalcopyrite is by all means the most important copper-bearing mineral on Prince William Sound. * * * The chalcopyrite is usually intermixed with pyrrhotite, which in itself carries probably a little copper sulphide as an impurity. * * * Pyrite, also 
probably carrying a little copper, occurs in some places, and chalcocite has been found in at least one prospect, and original native copper has been reported from another. Secondary copper minerals are of small importance, as weathering has extended only a short distance below the surface, but malachite, azurite, covellite, and native copper occur in small amounts. The other metallic minerals in the ore deposits are galena, sphalerite, and magnetite, but these are unimportant. The associated nonmetallic minerals are quartz, calcite, epidote, and chlorite."

The Ellamar mine is referred to as a "lens-shaped body of ore (chalcopyrite and pyrrhotite in varying proportions)."

"Positive conclusions as to the origin of the ore deposits are not warranted by the information at hand. The close association of the deposits with the greenstones points to these rocks as a probable source of the ore minerals. The deposits are, however, clearly of later date than the solidification of these rocks, and the shear zones in which the ores occur are as late or later than the folding of the country rocks. If there are other basic rocks later than, or contemporary with the folding and fracturing, they are not always clearly recognizable; yet in a few cases basic dikes are known which do not seem to have been affected by the folding of the district. That the ores originated from basic igneous rocks seems clear, but whether from magmatic waters derived from rocks later than the greenstones, or from ground waters acting on these greenstones, is not so clear. The decrease in thickness of the ore deposits in depth, at least as far as present information would lead one to conclude, points to the fact that the deposits are in the main in the nature of secondary enrichments. Such enrichments by downward-moving waters probably took place before the district was glaciated. During glaciation the upper leached parts of the deposits, as well as some of the euriched portions, were removed."

1910. Grant, U. S., and Higgins, D. F., Reconnaissance of the geology and mineral resources of Prince William Sound, Alaska: U. S. Geol. Survey Bull. 443, pp. 52-62. -

This report is the final complete statement of the views of Grant and Higgins as to the relations, character, and genesis of the copper deposits of Prince William Sound.

Mineralogy of the ore.-Chalcopyrite is given as the most important copper mineral. Pyrrhotite, pyrite, galena, sphalerite, and magnetite are associated with chalcopyrite. Gangue minerals are quartz, calcite, epiclote, chlorite, and other alteration minerals. Secondary minerals are not of great importance. Malachite, azurite, covellite, native copper, melaconite, bornite, chalcocite, and cuprite are mentioned. The "minerals have not usually been deposited in open cavities but occur as impregnations and as replacements of the country rock."

Paragenesis of the ore minerals.-The order of deposition of the various minerals is discussed briefly: "Chalcopyrite, pyrrhotite, and pyrite usually appear to be simultaneous in origin. Galena and sphalerite occur with these three, but are in places apparently earlier in date. Much of the quartz is intimately associated with the minerals just mentioned, and much of it is distinctly later than those minerals. Calcite is usually later than the others. * * * A few small veins of chalcopyrite and of pyrrhotite are * * * later than the main deposits. *** In one place a small quartz vein had its center filled with pyrrhotite, the quartz projecting into this mineral in crystal form, and one small vein of calcite was noted where pyrrhotite formed the center." 
Characteristics of the ore deposits.-The ore deposits commonly occur in shear-zones. In these zones the country rock is usually schistose. Along the zones there has been mineralization of the rock, chalcopyrite, pyrrhotite, and pyrite having been deposited as impregnations and as replacements of the country rock. The country rock of these zones is mainly greenstone, although some slate and graywacke are present, and in some places the shear zones follow closely the contact of these sediments with the greenstone. At the deposits on Latouche Island and on the south side of Fidalgo Bay, the country rock is slate and graywacke.

In a few localities there are rather sharply defined veins filled with quartz, pyrrhotite, pyrite, and chalcopyrite. In such localities there was apparently an open cavity, which was later filled with these minerals. There is no distinct banding to the veins, and the minerals are of one general date. "It is improbable that there were ever any large cavities in the shear zones. The ore minerals were deposited in part along the shearing planes, but especially in the sheared rock, both by impregnation and replacement."

The Ellamar and Bonanza ore bodies are somewhat different from the shear-zone deposits. The Ellamar ore body is a lens-shaped mass, probably "of the same general nature as the solid sulphide layers so common in the usual shear zones." The Bonanza mine is on a shear zone, but the movement has resulted in fracturing rather than shearing; the country rock is largely a very fine grained hard flinty rock.

Deposits near Orca are of markedly different type. Here the country rock is a much crushed reddish amygdaloidal basalt, with irregular stringers of epidotized rock. With the epidote is quartz. "The ore, which is native copper, chalcopyrite, bornite, and chalcocite, occurs associated with and in the epidote-quartz stringers, although in places it is associated with the nonepidotized country rock."

Genesis of the ore deposits.-The copper deposits are found either in or in close connection with basic igneous rocks. The ores occur in zones along which there has been fracturing or shearing or both. The ores minerals are of more recent date than most of this fracturing and shearing, which has taken place during or after the last folding of the rocks of the Orca group. The ore deposits, consequently, are of considerably later origin than most of the basic igneous rocks of the district, which are contemporaneous with the Orca sediments and which were involved in the above-mentioned dynamic disturbance. Small intrusions of diabase not affected by dynamic metamorphism are cited. These are given as evidence of intrusion of basic igneous rocks at a date later than the formation and folding of the rocks in which the ore deposits lie. It is stated, however, that the relations of these later igneous rocks to the shearing and fracturing and to the ore deposits themselves is not definitely known.

It is concluded that the ore deposits "were probably formed under somewhat deep-seated conditions and probably in connection with the intrusion of basic igneous rocks.".

"An alternative hypothesis for the origin of at least some of these ore deposits would suggest a primary origin, somewhat similar to that outlined above, followed by secondary enrichment of the upper parts of the veins by downward-percolating surface waters before the last glaciation of the district. During glaciation the upper leached parts of the veins were removed, and there are thus left to-day the lower parts of the enriched portions, which grade downward into the leaner nonenriched primary deposits." This ex- 
planation is applied to some of the deposits near Orca, where secondary minerals are more abundant than in other parts of the Prince William Sound region and to the Bonanza mine on Latouche Island.

The copper prospects are all in a recently glaciated region. Postglacial weathering has extended to only a short distance, only a few feet or even a few inches, below the surface. "There has thus been very little surface alteration of the ore bodies and consequently little recent secondary enrichment."

Mine; and prospects.-Descriptions are included of several of the mines and prospects of the Ellamar district.

The 'Threeman Mining Co.'s veins on Landlocked Bay "are in greenstone, graywacke, and slate, and consist of schistose shear zones carrying chalcopyrite and pyrrhotite."

The ore deposits of the Standard Copper Mining Co. are referred to as schistose areas in the greenstone of Copper Mountain carrying lens-shaped bodies of ore.

At the Reynolds Alaska Development Co.'s prospect on Boulder Bay the ore body is in interbedded greenstones, slates, and graywackes-a few veins of chalcopyrite. Locally disseminated chalcopyrite and a few veins of the same mineral are found in the greenstone.

Ellamar mine.-Ore body is lens-shaped. It "consists of chalcopyrite, pyrite, pyrrhotite, and country rock. Commonly the rock is lacking and the ore body is practically solid sulphides. *** The country rock is soft black slate, with a few bands of graywacke and black limestone. * * * The ore is in the main massive and not fractured, although there are some small cracks which have been filled by calcite and quartz."

1911. Brooks, A. H., Geologic features of Alaskan metalliferous lodes: U. S. Geol. Survey Bull. 480, pp. 80-82.

"The fourth group of copper deposits comprises those which are associated with greenstones (altered volcanic rocks) and sediments of various types. These deposits, so far as known, have no direct relation to igneous intrusive rocks, but it is possible that in the deposits of the Prince William Sound type belonging to this group there may be a connection between the genesis of the ores and certain basic intrusive rocks. *** While definite proof is lacking, it seems probable that the copper of * * * the Prince William Sound *** deposits was derived from copper minerals disseminated in the associated ancient volcanic rocks." An abstract is also given of the report of Grant and Higgins (U. S. Geol. Survey Bull. 443). Also states that "while these deposits have not been traced to the mineralizing influence of igneous rocks, yet Grant and Higgins have pointed out that certain basic intrusives are later than the shear zones and that the ores may bear a genetic relation to these rocks."

1911. Butler, B. S., Copper: U. S. Geol. Survey Mineral Resources, 1910, pt. 1, p. 160.

Places the formation of the copper deposits of Alaska in the Mesozoic era.

1912. Butler, B. S., Copper: U. S. Geol. Survey Mineral Resources, 1911, pt. 1, p. 259.

Places copper deposition in Alaska in the Mesozoic era.

1913. Capps, S. R., and Johnson, B. L., Mineral deposits of the Ellamar district: U. S. Geol. Survey Bull. 542, pp. 86-124.

Preliminary report. Conclusions are discussed in greater detail in this report. 


\section{GEOLOGIC DISTRIBUTION AND RELATIONS OF THE MINERAL DEPOSITS.}

GENERAL FEATURES.

The present geographic distribution of the mineral deposits of the Ellamar district is the result of a combination of geologic conditions, partly structural and partly geochemical. A close examination of the distribution of the mineral deposits shows that without exception they are closely connected with faults and it is evident that the main channels necessary for the passage of the mineralizing solutions were furnished by the numerous faults which traverse the area. The deposition of the contents of these solutions was favored in places by the crushed filling of shear zones in greenstone, by certain sheared and brecciated zones in sedimentary rocks of the Orca group, and in a few localities by open fissures in either greenstones or sedimentary rocks.

\section{STRUCTURAL RELATIONS.}

Distribution of fissuring and faulting.-The area is complexly faulted, and the distribution and relationships of the formations shown on the geologic map (Pl. II) are largely the result of faulting. The major fault of the area is the Landlock overthrust, the trace of which within the area mapped extends from the divide between Landlocked Bay and Fish Bay across the heads of Landlocked and Galena bays to Valdez Arm. By this fault the slate and graywacke of the Valdez group have been overthrust from the northeast on the interbedded slate, argillite, graywacke, greenstone, and conglomerate of the Orca group. The structural features of these two formations have already been discussed (pp. 33-34 and 44-45).

The rocks underlying and bordering the Landlock overthrust fault were extensively sheared and faulted. This shearing and shattering of the sediments of the Orca group is observable over a wide area bordering the trace of the Landlock overthrust on the east slope of Copper Mountain and on the ridge between Vesuvius Valley and the gap between Boulder and Galena bays.

Faulting is common in other parts of the area. One large shear zone is present on the southeast shore of Landlocked Bay near the lower end of the bay and another underlies the Ellamar ore body on Virgin Bay. Numerous shear zones visible on the north and south, flanks of Copper Mountain are traceable over considerable distances as shallow troughs or gullies where erosion has removed some of the soft sheared material. Topographic and geologic evidence suggests the presence of many faults whose contacts can not be definitely 
located because of the extensive cover of Quaternary deposits or vegetation. As an example may be cited the probable fault between West and Cloudman bays on Bligh Island, which separates the greenstone of the eastern peninsula from the gently folded slate and graywacke of the main part of the island.

Relation of fissuring and faulting to structure.-The location of the fissures has been determined by lines of weakness in the rock groups involved in the deformation of the district. Slates are interbedded in the greenstone and in many places the position of the shear zone has been determined by these interbedded masses of slate. The greenstones are very massive, and it is to be expected that the movements would be along the less resistant slate beds. The contacts of the greenstone and slate would also be natural lines of weakness and would give way under strain and permit shearing or overthrusting.

With the exception of the Ellamar ore body the important lodes do not parallel the bedding of the surrounding country rock. It is natural that both the lode and the bedding of the country rock should be parallel in those places where the lode is an impregnation and replacement of a closely compressed series of thin-bedded vertical sediments sheared along the strike of the bedding, as at Ellamar. Where the shearing has taken place along the sediments a parallelism of the lode and bedding is noticeable, but where the lodes are due, as in most places, to the cementation and replacement of shear zones or the filling of fissures which crosscut the bedding, no parallelism between bedding of country rock and lodes exists.

Type of faulting.-Most of the faults of the district are shear zones, and it appears probable that most of the faulting is of the reverse or overthrust type. This is of course evident in faults like that of the Landlock overthrust, where the Valdez rocks have been overthrust from the northeast toward Prince William Sound, overriding beds of Orca age. These overthrust faults indicate a lateral compression of the beds. involved. No cross or transverse faults (tension type) are known.

Age of faulting and fissuring.-The date of the last great deformation of the rocks of this district is not definitely known, but it is presumed to be about that of the intrusion of the granites of the sound. It is later than any of the rocks present in the Ellamar region, since all of these rocks are involved in the deformation. Most of the faulting appears also to have occurred before the deposition of the ore, although the presence of slickensides on some of the sulphide ore lenses, as at Ellamar, is indicative of postmineral movement along the fault planes. Jointing is also evident in the massive pyrite lens of the Ellamar ore body. These later movements, how- 
ever, appear to have been slight, and the mineral deposits apparently stand in approximately the same attitudes that they had when originally formed.

Fissure systems.-Two fairly well defined systems of shearing and faulting are recognizable, the faults of one system striking a.little east of northeast and those of the other west-northwest. ${ }^{1}$ (See fig. 5.) The west-northwest system of fissuring, which parallels in a general way the strike of the Landlock overthrust fault, is the more prominent

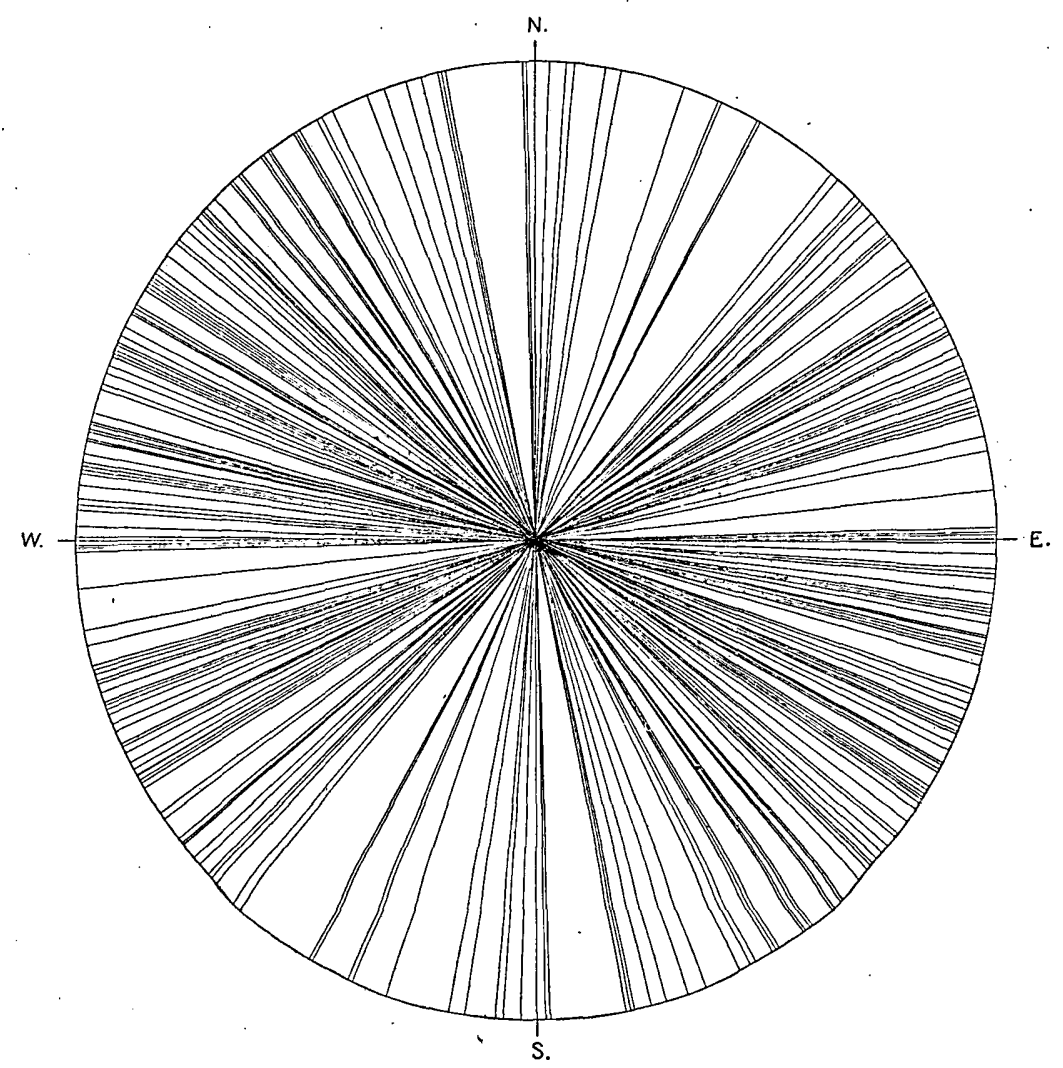

FIGURe 5.-Strike of fissures in Jillamar district.

and contains the larger number of shear zones and faults. The dips of both systems are steep, generally from $55^{\circ}$ to $90^{\circ}$.

Relation of the ore deposits to fissuring.-All the mineral deposits are closely connected with faults or fissures. They are most abundant in the highly faulted and sheared belt bordering the trace of the Landlock overthrust fault, where the shattering has been most intense. None are known in the comparatively little disturbed sections, such as Bligh Island and the region between Gladhaugh Creek and Galena Bay. 
RELATION OF THE MINERAL DEPOSITS TO THE COUNTRY ROCK.

The mineral deposits of the Ellamar district occur in both the igneous and sedimentary rocks of the Orca group. The distribution of the geologic formations of the district is shown on Plate II (in pocket). The greenstones (basic lavas) contain most of the copper deposits, which occur chiefly in the highly faulted and shattered parts of the formation. Within the sedimentary areas the Ellamar ore body is the only known copper deposit in the district. It is evident, therefore, that conditions in the sedimentary areas were much less favorable than in certain parts of the greenstone areas for the deposition of metallic ore minerals from solutions of the character of those circulating through the rocks at the time the mineralization of the area took place. It has already been pointed out that the ore bodies occur only in connection with extensive structural dislocations. The conglomerate areas are small, have suffered but slight deformation, and contain no copper deposits. The slightly disturbed slates and graywackes of Bligh Island are not known to contain any copper ores. Certain of the slate-graywacke areas or black slate belts of the mainland have been closely folded and faulted.- Even these, however, throughout most of their. extent exhibit no indications of metallization. At Ellamar, however, impure limestone strata are interbedded with the slates and graywackes of the Orca group. This series of beds has been shattered and sheared and later mineralized. Impure limestones have been noted in one or two other parts of the district but in slightly deformed areas where the mineralizing solutions failed to obtain access.

The greenstones, argillites, and graywackes of the Orca group bordering the Landlock overthrust fault have been minutely shattered over a considerable area. The fractures in the argillites and graywackes have been closed by tiny reticulating mineralized quartz veinlets in which the metallic minerals are widely scattered. There is practically no mineralization of the country rock in this type of deposit. The similarly shattered areas in the greenstones appear to be somewhat more highly mineralized as a result of a slight metallization of the greenstone associated with the ore.

Open fissures in both the greenstones and the sedimentary rocks have been filled by quartz veins, which, so far as known, are only slightly mineralized. Their relation to the copper deposits is in general unknown. In one place, however, a gradation was observed along the strike from a copper-bearing shear zone in the greenstone to a quartz-filled fissure vein in the same rock. The quartz vein carried few sulphides. The quartz veins do not appear to show any greater development in one than in another type of rock,

$86673^{\circ}-$ Bull. $605-15-5$ 


\section{CHARACTER OF THE ORE DEPOSITS.}

Mineral deposits may be classified in many ways. Those most commonly employed are based on uses, economically important metal, mineral composition, character of country rock, form, and genesis.

The only mineral deposits of the Ellamar district at present commercially important are metallic ores. The principal valuable metal is copper, but the ores generally carry gold and silver. The ore minerals are chiefly sulphides, chalcopyrite, pyrrhotite, and pyrite predominating, with smaller amounts of sphalerite, galena, arsenopyrite, and an undetermined minéral, presumably a copper-iron sulphide. Nonmetallic minerals introduced contemporaneously with the sulphides form but a slight percentage of the ores. The deposits are most abundant in the greenstones but are also found in the sedimentary rocks. The deposits are believed to be primary impregnations by sulphide minerals of the crushed filling of shear zones in greenstones of the Orca group and of certain sheared and shattered zones (presumably calcareous) in the Orca sediments. The copper deposits are shear-zone deposits, both in the greenstones and sedimentary rocks. The ore minerals cement many small fractures of the shattered rock and replace other portions of the rock. Quartzfilled fissure veins carrying similar mineral associations occur but are not numerous. The evidence thus far obtained indicates that the mineralization was performed under moderately deep seated conditions by hot alkaline mineral-bearing solutions of magmatic origin, circulating shortly after the intrusion of the Mesozoic granitic rocks of the Prince William Sound region and probably genetically related to them. The evidence on which this view of the genesis is based is given on pages $82-84$.

As noted above most of the ore deposits of the Ellamar district appear to be the result of primary impregnation by sulphide minerals of shear zones in greenstone or, as at Ellamar, in sedimentary beds. Only a few sharply defined quartz-filled fissure veins have been found and one of these changes along its strike to a mineralized shear zone that carries principally sulphides and but little quartz. Large masses of low-grade ore are found on the north and east slopes of Copper Mountain, where the Orca rocks, now lying west of the trace of the Landlock overthrust fault, were minutely shattered by the faulting. In the argillites and graywackes the fractures were cemented by tiny reticulating mineralized quartz veins. Within similarly shattered greenstones a certain amount of mineralization of the wall rock occurred together with the cementation of the fractures by the quartz veinlets. Considerable areas were thus slightly mineralized. 
The greenstone shear-zone type of copper deposit is the most numerous, and most of the prospects in this district have been located on deposits of this character. The width of the greenstone shear zones ranges from a few inches to several feet, but the exact width is in many places hard to determine because of cover, lack of sharp boundaries between sheared and unsheared rock, or the inclusion of horses of unsheared rock within the shear zone. Many of the shear zones are of considerable length; some on Landlocked Bay having been traced 900 to 1,500 feet.

The metallization within these greenstone shear zones changes vertically, laterally across the shear zone, and along the strike of the zone. Masses of nearly solid sulphides, lenticular both in plan and section, are irregularly distributed within the sheared material. Several ore lenses thus occur within a single shear zone. Some of these may not be yet uncovered by erosion. Others are but partly exposed, as at the property of the Threeman Mining Co. on Landlocked Bay, where the tip of a steeply dipping sulphide lens in a shear zone striking at right angles to the hillside barely cuts the surface of the more gently sloping hillside. At Ellamar a considerable part of the upper portion of the lode has apparently been eroded.

Development work on the shear zones has not yet outlined many large sulphide lenses. The thickness of the known lenses ranges from mere films to several feet, but at most of the prospects thicknesses of more than 5 feet are not common. The maximum thickness reported is $9 \frac{1}{2}$ feet, on an ore body, largely sulphides, whose maximum stope length, as developed, is about 70 feet and whose pitch length, as now exposed, is over 200 feet. This ore body, however, is not one solid lens but a compact combination of smaller lenses of different sizes. The smaller lenses are much more common. Outside of these solid or nearly solid sulphide lenses the other portions of the shear zones are less highly metallized.

Because of the nearly vertical position of the shear zones it naturally follows that the lodes of the greenstone shear-zone type of deposit are also nearly vertical. The strikes also correspond with those of the containing shear zones. Many of the ore lenses, though corresponding in strike and dip with the containing shear zones, pitch steeply within the plane of the shear zone.

The deposits of sulphide ores in sedimentary rocks are represented in the Ellamar district by but one example, the ore body of the Ellamar mine. This is the largest body of massive sulphide ore yet found in this district. Erosion has removed the upper part of this ore body, but the greatest horizontal dimension of the ore lens appears to have been about 90 by 240 feet. The ore body at present 
known pinches out between 500 and 600 feet below sea level. No definite conclusions can be drawn regarding the sizes of ore bodies of this type, as no others have thus far been found within this district. A detailed description of this particular ore body is given on pages 90-92.

The intense glacial scouring to which all this district has been subjected has exposed the primary ore bodies at the surface. Any preglacial enriched zones or weathered parts of the lodes which may once have existed were removed by the glaciation, the recency of which has, moreover, afforded little opportunity for surface alteration of the ore deposits. Recent weathering has extended a few inches below the surface and in most places the alteration is only partly complete. There is thus no considerable leached zone in the upper portions of the lodes and consequently no postglacial enriched zones. Though chemical agents have altered the deposits but little, physical processes have been more active. The soft filling of the shear zones is readily removed by degradation and the shallow troughs formed are traceable in many localities over considerable distances.

\section{ORE MINERALS.}

\section{GENERAL FEATURES.}

The mineralogy of the ore deposits of the Ellamar district is extremely simple. The economically important minerals are chiefly sulphides. Gold is present, probably native. It has not been recognized in any of the specimens examined, but its presence is proved by the assay returns. Silver is also reported in small quantities in the ores, probably in part alloyed with the gold. Secondary minerals are rare and of no economic importance.

The minerals reported by different writers to occur in the ore deposits of the Ellamar district are here tabulated. The reports cited show that many of these minerals occur in the Prince William Sound region, but do not state that they occur in the Ellamar district. However, so far as the present writers are aware, any mineral found in the larger region may be found within the arbitrary limits chosen in this report for the Ellamar district, so that all the minerals mentioned in these earlier reports are here included. Those minerals which are definitely stated as found within the limits of the Ellamar district as defined in this report have been assigned a distinct symbol (•). 
Ore minerals mentioned in reports that refer to the Ellamar district.

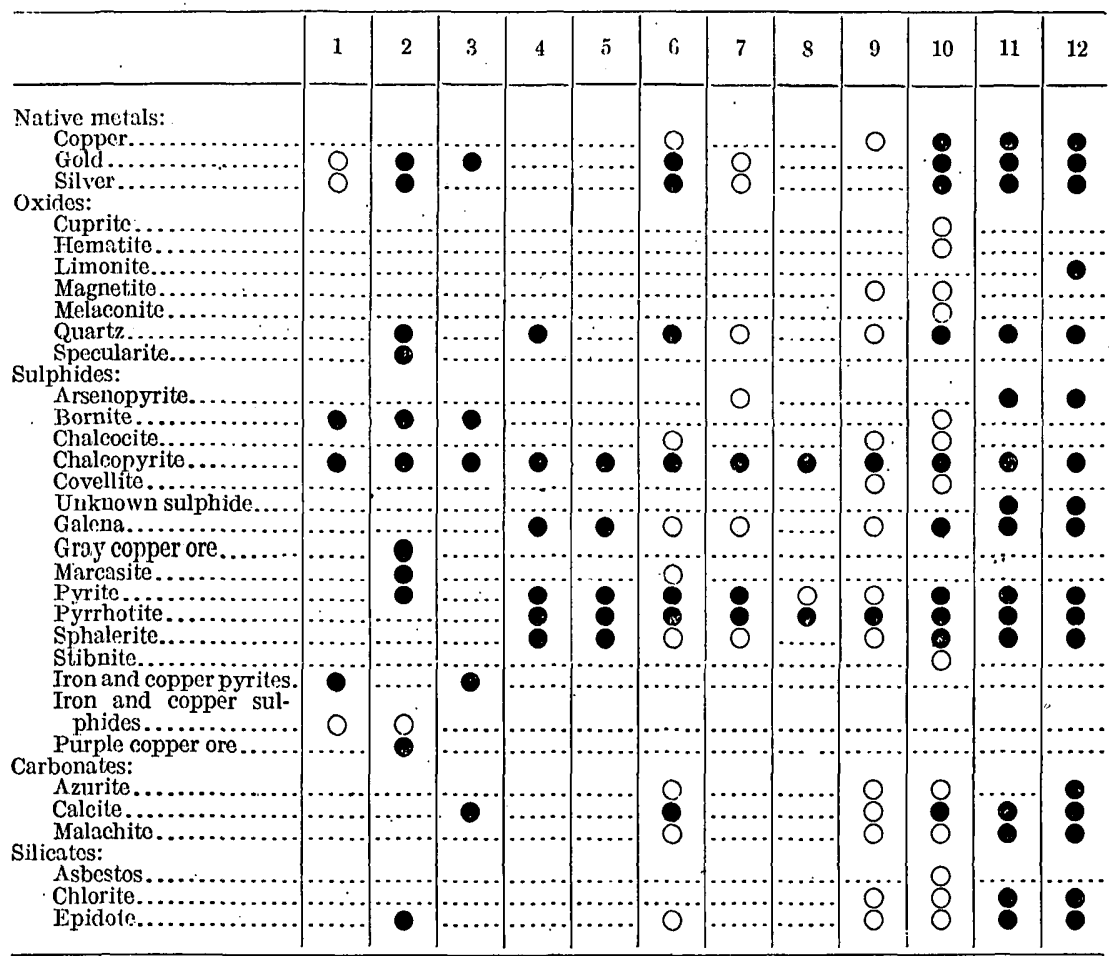

NoTE.-Minerals reported to occur in the ore deposits of the Ellamar district indicated by $\bullet$. Minerals mentioned as found in the Prince William Sound region but not definitely stated as occurring in the Ellamar district indicated by $O$.

1. Schrader, F. C., Report on Prince William Sound and the Copper River region, in "Maps and descriptions of routes of exploration in Alaska in 1898, with general information concerning the territory," U. $S$. Geol. Survey special pub., pp. 51- $63,1899$.

2. Schrader, F. C., A reconnaissance of part of Prince William Sound and the Copper River district, Alaska, in 189s: U. S. Geol. Survey Twenticth Ann. Rept.,pt. 7, pp. 347-423, 1900

3. Schrader, F. C., and spencer, A.C., The geologv and mincral resources of a portion of the Copper River district, Alaska: U.' S. Geol. Survey special pub., ion.

4. Emerson, B. K., General geology: Alaska, vol. 4, Harriman Alaska Expedition, pp. 11-56, 1904.

5. Palache, Charles, Notes on the minerals collected: Alaska, vol. 4, Harriman Alaska Expedition, pp. 91-96, 1904 .

6. Grant, U. S., Copper and other mineral resources of Prince William Sound: U. S. Geol. Survey Bull. 2S4, pp. $78-87,1906$

7. Grant, U. S., and Figgins, D. F., jr., Copper mining and prospecting on Prince William Sound: U. S. Geol. Survey Bull. 379, pp. 87-96, 1909 .

8. Stevens, Blamey, Prince William Sound, its geology and mineralogy: Northwest Min. Jour., vol. 8 , pp. 3-6, 1909.

9. Grant, U. S., Copper deposits of Prince William Sound, Alaska: Min. and Sci. Press, vol. 100, pp. 63$64,1910$.

10. Grant, U. S., and Higgins, D. F., Reconnaissance of the geology and mineral resources of Prince William Sound, Alaska: U. S. Geol. Survey Bull. 4\$3, 1910 .

11. Capps, S. R., and Johnson, B. L., Mineral deposits of the Ellamar district: U. S. Geol. Survey Bull. 542 , pp. 8i-124, 1913.

12. Capps, S. R., and Johnson, B. L., this report.

The earlier reports contain references to the presence of marcasite, bornite, specularite, and gray copper ore in the ore deposits of the Ellamar district, minerals which have not been detected in the present investigation. Bornite has not been noticed by the present writers and it appears probable, since pyrrhotite is not mentioned as a characteristic ore mineral by the early writers, that this mineral was mistaken for bornite. Marcasite is hardly to be expected in primary sulphide ore deposits, such as are found in this region. Its presence 
can not be considered as proved. No mineral recognizable as such was seen during recent examinations. Specularite and gray copper ore have not been observed.

The accompanying table gives, in alphabetic order, the minerals recognized in the ores of the Ellamar region by the present writers. Only those minerals are listed which constitute or accompany the ore deposits. The original constituents of the wall rocks which have not been affected by the mineralizing solutions are not included.

Minerals occurring in the ore deposits of the Ellamar district.

\begin{tabular}{|c|c|c|}
\hline Mineral. & Composition. & Occurrence. \\
\hline Arsenopyrite. & FeAsS & Associated with other sulphides at old Alaska Commercial \\
\hline Azuri & $2 \mathrm{CuCO}_{3} \cdot \mathrm{Cu}(\mathrm{OH})$ & Oxidation product of the copper sulphides. \\
\hline 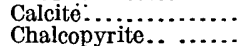 & $\mathrm{CaCO}_{3}-$ & Gangue mineral of the ores. \\
\hline $\begin{array}{l}\text { Chalcopyrite........... } \\
\text { Chlorite............. }\end{array}$ & $\begin{array}{l}\text { CuFespex hydrous sili- } \\
\text { cate of } \mathrm{Fe}, \mathrm{Mg} \text {, and }\end{array}$ & $\begin{array}{l}\text { Principal copper-bearing mineral of the ores. } \\
\text { Alteration product of minerals of wall rock of ore kodies. }\end{array}$ \\
\hline & Al. & vidation mrad net ofon \\
\hline Epido & $\begin{array}{l}\text { Complex hydrous sili- } \\
\text { cate of } \mathrm{Ca}, \mathrm{Al} \text {, and }\end{array}$ & $\begin{array}{l}\text { Oxidation product of copper minerals of ore. } \\
\Lambda \text { gangue mineral in some of the ores. }\end{array}$ \\
\hline Gal & Pbs. & One of the sulphides of the ores. Not very common. \\
\hline & Au. & Present in most of the ores. Relationship unknown. \\
\hline $\operatorname{Lim}$ & $2 \mathrm{Fe}_{2} \mathrm{O}_{3} .3 \mathrm{H}_{2} \mathrm{O} \ldots$ & Oxidation product of iron minerals. \\
\hline Malachit & $\mathrm{CuCO}_{3} \cdot \mathrm{Cu}(\mathrm{OH})_{2}$ & Oxidation product of the copper sulphides. \\
\hline & $\mathrm{FeS}_{2}$ & A bundant ore mineral at some prospects. \\
\hline Py & FeS(S) $x$. & Abundant ore mineral at most prospects. \\
\hline & $\mathrm{SiO}_{2} \ldots \ldots \ldots$ & Gangue mineral of the ores. \\
\hline & $\mathrm{Ag}(\mathrm{Fe}) \mathrm{S} \ldots \ldots \ldots$ & $\begin{array}{l}\text { Presence in ores shown by assays. } \\
\text { A common ore mineral. }\end{array}$ \\
\hline Unknown s & $\begin{array}{l}\text { Probably an isomor- } \\
\text { phous mixture of } \\
\text { covelliteandpyrrho- } \\
\text { tite. (See pp.95-96.) }\end{array}$ & $\begin{array}{l}\text { Intimately associated with chalcopyrite at Threeman } \\
\text { Mining Co.'s mine on Landlocked Bay. }\end{array}$ \\
\hline
\end{tabular}

It is possible also to make a genetic classification of the minerals that occur in the deposits of the Ellamar district. Certain minerals existed originally in the sedimentary rocks of the region. Others were introduced or developed by metamorphism during the extrusion of the basic lavas. Other minerals were contained in these lavas. Certain minerals were developed during the subsequent intense deformation of both sedimentary and igneous rocks. 'The ore-bearing solutions introduced or formed still others, and recent weathering (oxidation) has resulted in the slight development of minerals characteristic of that condition. Tabulated, this distinction can be shown thus:

Pre-ore minerals:

1. Original in the sedimentary rock.

2. Developed by metamorphism by lavas.

3. Constituents of lavas and later sediments.

4. Minerals developed during deformation of region.

Ore minerals and later:

5. Minerals introduced by ore-bearing solutions.

6. Oxidation products (secondary from ore minerals). 
copper, silver, and gold. One of the results of this investigation has been to show that the copper occurs apparently as a definite mineral, chiefly chalcopyrite, and not chemically combined with pyrite. This agrees with the conclusions of Simpson ${ }^{1}$ on the copper ores of Butte, Mont., and with Finlayson ${ }^{2}$ on the pyritic deposits of Huelva, Spain.

The pyrite, under the metallographic microscope, is shown definitely to be of a slightly earlier generation, cut and replaced by the later chalcopyrite. The massive pyrite lens of the Ellamar mine shows very little copper content in assays. Metallographic examinations of this pyritic ore invariably show the copper content to be contained in the later chalcopyrite. Qualitative tests on a pale brass-yellow sulphide intimately associated with the chalcopyrite at the mine of the Threeman Mining Co., on Landlocked Bay, show that this mineral has apparently a low copper content. A careful determination of this mineral is being made. (See pp. 95-96.) No other primary copper-bearing minerals are found in the ores and no evidences of any copper silicates were seen in any of the ores or rocks examined in the Ellamar district.

Gold has not been observed in any of the specimens examined. Its presence in both copper and gold ores of the district, however, is amply proved by the results of assays. The Ellamar mine, formerly chiefly a copper producer, has in recent years produced large quantities of gold. This metal is also found in the Threeman ore. Though it is not definitely known that the gold occurs native, no tellurides or other gold minerals are known to occur in this district, and by analogy it is presumed, until further evidence is produced, that here, as in other parts of the Pacific coast region where similar genetic relationships exist, the gold occurs native.

Assay returns show the presence of silver in the gold and copper ores of the Ellamar district, but the metal has not been seen in any specimen examined. Inasmuch as all lode gold contains some alloyed silver, a part at least of the silver in the ores of the Ellamar district is presumed to occur alloyed with the gold of the lodes. No silver minerals have been found in this district.

\section{SECONDARY COPPER MINERALS.}

Secondary copper minerals are of little importance in this district. Green malachite stains are visible at many prospects, and here and there azurite, the blue copper carbonate, is seen. Small flakes of native copper have been found in the weathered outcrops of the copper lodes on the property of the Threeman Mining Co. and on the prospects of L. P. M. Falck, on Landlocked Bay.

1 Simpson, J. F., The relations of copper to pyrite in the lean copper ores of Butte, Mont.: Econ. Geology, vol. 3, p. 628,1908 .

2 Finlayson, A. M., The pyritic deposits of Huelva, Spain: Econ. Geology, vol. 5, p. 420, 1910. 


\section{GENESIS OF THE ORES.}

\section{VALUE AND SCOPE OF THE DISCUSSIONं.}

The question of the genesis of the ores of any district is of much practical importance in any careful estimate of the future of that district, in the determination of the most economic mining and metallurgic treatment of the ores, and in ascertaining those parts of the district in which prospecting would most likely yield favorable results. For these reasons certain generalizations as to the genesis of the ores of the Ellamar district, in accord with the present knowledge of the science of ore deposition, are here drawn from the observations recorded in the preceding pages regarding the character and occurrence of the metallic ores of this district.

It should be pointed out first that the Ellamar district is but a small part of a much larger area. (the Prince William Sound region) in which similar conditions of mineralization exist. Any broad general laws applicable to the entire area should be based on principles of wide application, and the processes taking place in accordance with these general laws should yield results of common occurrence. The broad relations shown by general laws should serve, as Umpleby ${ }^{1}$ has suggested, as primary control in the interpretation of local detailed observations. Conversely, the facts gathered regarding the mineral deposits of one part of a large mineralized area should fit in a broad general genetic classification of the mineral deposits of the whole region.

The views of previous writers regarding the genesis of these ores are given elsewhere in this report. Basic igneous rocks have heretofore been presumed to have something to do with the formation of the ore deposits. The present writers, in a recent publication of the United States Geological Survey,2. suggested a possible genetic origin for the ores of the Ellamar district considerably at variance with those of earlier investigators. The conclusions there presented are here discussed in some detail and it is believed that they present the most logical explanation of the distribution and occurrence of the ores of the Ellamar district yet presented. It further appears that the conclusions are applicable not only to the Ellamar district but to most, if not all, of the mineral deposits of the entire Prince William Sound region.

PERIODS OF MINERALIZATION IN PRINCE WILLIAM SOUND REGION.

Many of the ore deposits of the Prince William Sound and adjacent regions have been examined in more or less detail. The association of primary minerals in the ores of the various districts included in

1 Umpleby, J. B., The lead-silver deposits of the Dome district, Idaho: U. S. Geol. Survey Bull. 540, p. 58,1914 .

2 Capps, S. R., and Johnson, B. L., Mineral deposits of the Ellamar district: U. S. Geol. Survey Bull. 542, pp. 102-105, 1014. 
these regions, whether from gold quartz or copper lodes, is almost identical, however great the disparity in the relative proportions of the different minerals present in the ores or in the mode of occurrence of the ores. This is evident from the lists already published of the primary ore minerals occurring in the lodes of the Seward-Sunrise district $^{1}$ on Kenai Peninsula, the Valdez district, ${ }^{2}$ and the Ellamar district. $^{3}$ These occurrences are tabulated here for convenience of comparison.

Primary mineral associations in the Seward-Sunrise gold quartz, Valdez gold quartz, and Ellamar copper districts.

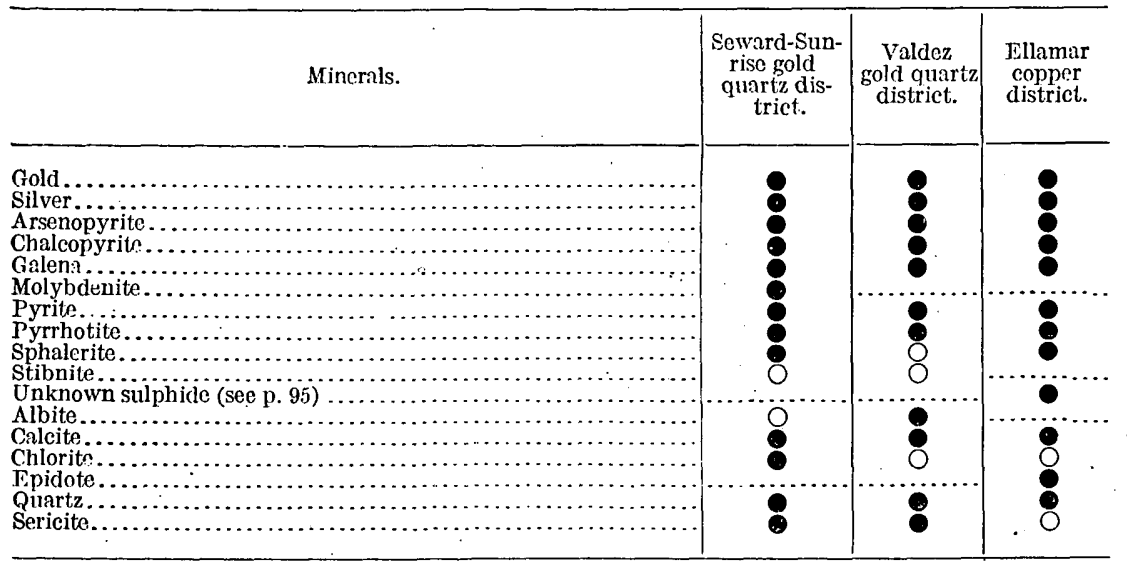

Note.-Minerals observed in these districts but not mentioned in the reports cited above are indicated by $O$. Minerals whose occurrence is mentioned in those reports are indicated by 0 .

Two gold quartz districts and one copper district are included. Investigations, not yet completed, of other gold and copper ores of the region show similar mineral associations. This similarity of the primary mineral associations of the gold and copper lodes of the region is indicative of a common source of the ore-bearing solutions from which the ores were deposited, as well as a single period of mineralization, provided, of course, that field relations show no evidence of two distinct periods of mineralization with similar mineral associations. Not only has no evidence of this nature been recognized but in one instance an actual gradation has been observed, in the greenstone of Copper Mountain, from a sulphide-bearing shear zone to a quartz-filled fissure vein with low sulphide content, along the strike of the ore body. In this locality two markedly different forms of mineral deposits came from one common ore-bearing solution as a result of different physical conditions existing during the

1 Johnson, B. L., Gold deposits of the Seward-Sunrise region, Kenai Peninsula: U. S. Geol. Survey Bull. 520, pp. 131-173, 1912 .

2 Brooks, A. H., Gold deposits near Valdez: U. S. Geol. Survey Bull. 520, pp. 108-130, 1912.

3 Capps, S. R., and Johnson, B. L., Mineral deposits of the Ellamar district: U. S. Geol. Survey Bull. o42, pp. 8G-124, 1913. 
formation of the ore body. Though no other gradational examples are yet known, it appears reasonable to presume, in the absence of contradictory evidence, that many if not all of the gold quartz and copper lodes of the region with similar mineral associations were deposited from similar solutions at approximately the same time, and that therefore but one distinct period of primary mineralization existed in the Prince William Sound region.

\section{DEPOSITION OF THE ORES.}

It has been pointed out that there is apparently but one general period of mineralization. It has also been stated that the sulphides occur most abundantly in shear zones with but little quartz, whereas the quartz veins fill open fissures and carry but few sulphides. Gradations exist from one type to the other. The shear zones occur in both sedimentary and basic igneous rocks, but the sulphide ore bodies are by far the most common in shear zones in the greenstones. The quartz veins, so far as observed, show no preference for any particular type of rock. The data at hand seem to indicate that at the time of metallization the clean-cut fractures in all types of rocks were filled with quartz and minor amounts of sulphides, and that the shear zones in greenstones and in certain types of sedimentary rocks (limestones at Ellamar) were impregnated with and replaced by an abundance of sulphides and little quartz. The character of the country rock appears to have had considerable effect on the deposition of the ore minerals in the shear zones.

The causes which resulted in these peculiarities of distribution of the ores appear to have been partly physical and partly chemical. As will be shown later, the mineralization was moderately deep seated and it is known to have had a range of at least 3,000 feet. No marked differences in characteristics due to elevation have been observed in deposits situated in different portions of this range. Presumably there was little variation in temperature and pressure throughout the present known vertical extent of mineralization during the deposition of the ores.

The principal physical factor involved appears to have been the degree of comminution of the material of the shear zones previous to the metallization. All gradations from finely crushed to massive rock occur. Other things being equal, the not too finely pulverized material appears to have been the most favorable for the sulphide deposition, the crushed and shattered rocks exposing far greater surfaces, in proportion to their mass, to the chemical attack of the metallizing solutions than was afforded by the less shattered, more

- massive rock. Consequently, when other conditions were favorable these shattered portions were replaced by the ore minerals with much greater readiness than the more massive rock. 
As to the depth below the surface at which the deposition of the ore minerals took place, there is no positive direct evidence available on account of lack of data as to the extent of erosion of the overlying rock masses subsequent to the ore deposition. There is, however, the evidence furnished by the mineral association, which is that characteristic of ore bodies of deep-seated origin deposited under conditions of moderately high temperature and pressure and at a depth below the surface of several thousand feet as a minimum. 1 .

The mineral association in the different types of ore is practically the same, but a marked difference exists in the relative proportion of the minerals present. The principal gangue mineral of the veins is quartz, whereas in the shear-zone deposits quartz is not at all abundant. This mineral is usually assumed to exist in natural waters in the colloidal state, and it is possible that the finely crushed material of the shear zones acted as a semipermeable membrane and did not admit the colloidal silica but permitted the passage of the sulphides in solution through the crushed material, where they were deposited as a replacement of the crushed rock and a cement to tiny fractures. In open fissures this condition did not exist and the silica was deposited as quartz. It is also possible that some of the quartz now filling the fissures is silica set free during the alteration of the material of the shear zone by the metallizing solutions and carried out and deposited in the fractures.

The quartz lodes are undoubtedly the filling of open fractures by deposition of the gangue and ore minerals from aqueous solutions. The field evidence and that furnished by thin sections of the ores prove that ore deposits of the shear-zone type (sulphide ore bodies) were formed partly by the replacement of zones of sheeted and crushed rocks and partly by the filling of many tiny fractures in minutely shattered rock.

The field evidence of replacement consists of-

1. The absence of comb structure or vugs in any of the shear-zone deposits.

2. Inclosed horses of country rock-unreplaced remnants of the original country rock-within the lodes. These are not fragments of rocks broken off and inclosed in the ore as it was deposited.

3. Gradual transitions from slightly mineralized country rock to masses of solid sulphides.

4. Retention of traces of original structure, such as banding or - shearing, of the shear zones, in the ore.

5. Parallelism of the ore banding in places to the shear-zone walls.

6. Numerous unreplaced small masses of the crushed rock of the shear zone in masses of nearly solid sulphide ore, giving rise to a

${ }^{1}$ Lindgren, Waldemar, The relation of ore deposition to physical conditions: Econ. Geology, vol. 2, pp. 105-127, 1907. 
spotted ore seen in many of the greenstone shear-zone ore deposits. Presence of partly replaced, undigested fragments of country rock.

7. The fine-grained character of the sulphides.

8. Absence of crystals of any of the sulphides except pyrite, which in a few specimens shows crystallized form.

9. Difficulty of open spaces of the size of the massive pyrite lens of the Ellamar mine forming or keeping open long enough for the ores to have been deposited under the deep-seated conditions existing at the time of their deposition.

In many of the deposits in rocks such as graywackes, which were comparatively unattackable by the metallizing solutions, the numerous fractures and joints formed in the rocks during the development of the shear zone are cemented together by deposition of solid sulphides with no replacement of the wall rock. Numerous tiny openings in the sheared material were probably also filled by deposition of the sulphides in small open spaces, but the main features of the deposits appear to be due chiefly to a replacement of the sheared rocks, where these consist of greenstones or limestones.

Microscopic examination corroborates the field evidence that most of the sulphide ores have originated through replacement. Under the microscope the replacement of the dark limestone of the Ellamar mine by pyrite is clearly shown and also a partial recrystallization of the fine-grained limestone to a coarser-grained aggregate of dark calcite. Strain striations show on much of this dark-colored calcite, which, together with the shattered pyrite, is cut by small seams of later white calcite carrying the other sulphides. The later sulphides also replace portions of the country rock left unreplaced by the pyrite, as well as a portion of the pyrite. The dark and light calcite shows in many specimens from the massive pyrite lens as well as from other parts of this ore body. Most of the original fine-grained dark limestone, however, appears to have been completely replaced or recrystallized. The replacement by pyrite of certain thin parallel beds in dark-banded argillitic rocks, the major portion of which is unfavorable to replacement, is also seen in some specimens from the Ellamar ore body. Replacements of calcite (apparently recrystallized limestones) by sulphides are found in other deposits of the district, including some in greenstone shear zones, and it is probable that some of the sediments interbedded with the greenstones and involved with them in the folding and shearing were calcareous. Similar interbedded limestones and greenstones occur in the less deformed and unmineralized portion of the district.

The greenstones alter under deep-seated conditions with greater ease than do the slates and graywackes of either the Valdez or Orca groups, which is well illustrated by the comparatively fresh condition of the constituents of the sedimentary rocks, whereas much of 
the greenstone has undergone an appreciable amount of alteration, especially in the vicinity of the ore deposits. This is especially evident on microscopic examination of thin sections of the rocks, but it is also indicated in the field by the greater intensity of the green color in the more highly altered rocks, owing to the development of chlorite during the process of alteration. This readily alterable state is indicative of the existence in these basic igneous rocks of minerals that are unstable in the presence of metallizing solutions. Slides of sheared and mineralized greenstones showed the introduction of epidote, quartz, and sulphides after the development of the schistosity. In some places veinlets of these minerals crosscut the schistose structure, but in general, however, the metallizing solutions appear to have followed along the schistosity, which probably yielded easy passage for them. Chlorite and a little calcite are the chief secondary minerals in the altered rock. Comparatively little sericite is seen. The relationships of the calcite indicate that it is a recrystallization of an original limestone. Limestones interbedded with greenstones and which were later involved in the shearing have been observed in other places, and some if not much of the sulphide deposition in these greenstone shear zones is probably due to the calcareous nature of these included sediments.

\section{COMPOSITION OF THE ORE-BEARING SOLUTIONS.}

The chemical character of the ore-bearing solutions is indicated by the mineral composition of the ores deposited and the alterations of the rock that were effected by the metallizing solutions. The association of primary minerals in the ores of the Ellamar district-namely, chalcopyrite, pyrrhotite, pyrite, sphalerite, arsenopyrite, galena, gold, silver, an undetermined mineral that is apparently a copper-iron sulphide, quartz, calcite, and epidote-is that characteristic of primary ore bodies of deep-seated origin ${ }^{1}$ deposited by alkaline solutions ${ }^{2}$ under conditions of moderately high temperature and pressure. Such hot alkaline solutions are usually ascending waters. The rock alterations are correspondingly characteristic.

\section{COURSE OF THE ORE SOLUTIONS.}

Channels were necessary for the passage of the mineralizing solutions. The deformation of the area, already referred to (pp. 62-64), resulted in numerous faults and shear zones. Open fissures were rarely formed, probably because the reverse type of faulting (com-

1 Lindgren, Waldemar, The relation of ore deposition to physical conditions: Econ. Geology, vol. 2, pp. 105-127, 1907. Emmons, W. H., A genetic classification of minerals: Econ. Geology, vol. 3, pp. 611-627, 1908. Farrell, J. H., Practical field geology, pp. 127-138, New York, 1912.

2 Allen, E. T., and Crenshaw, J. L., Sulphides of zinc, cadmium, and mercury; their crystalline forms and genetic conditions: Am. Jour. Sci., 4th ser., vol. 34, pp. 341-396, 1912. Iindgren, op. cit., p. 121. 
pression faulting), of which the best example is the Landlock overthrust, is predominant in the area. The shear zones and faults furnished channels for the circulating mineral-bearing solutions, which appear to have circulated in them and to have penetrated but slightly into the massive rocks. The larger faults were naturally the main passageways for these waters, which appear to have risen principally along the Landlock overthrust and the large faults associated with it and circulated through the shattered rocks bordering the thrust plane of this great fault. Since many of these faults and shear zones cut sedimentary rocks as well as the greenstones the solutions passed through crushed and shattered rocks of both types. They also circulated in a few open fissures as well as filtered through the crushed material of numerous shear zones.

\section{SOURCE OF 'THE METALLIZING SOLU'TIONS.}

It has been shown that there was but one general period of metallization and it will be shown later that this one period of metallization of the Prince William Sound region took place subsequent to the granitic intrusion in that region. As noted previously, the mineralizing agents were probably heated aqueous solutions of an alkaline character carrying dissolved metals and gases. The ore-bearing solution was possibly either meteoric water heated by the granitic intrusions, magmatic water genetically related to the granites, or a mixture of both. The view is commonly accepted, however, that intrusive rocks are causatively related to the deposition of ores, especially of ores of the precious metals. The similarity of the mineral association over broad areas in this part of Alaska points to an extensive common source of the ores and ore-bearing solutions, one capable of generating solutions with great similarity of composition over a large area. It should be noted that the Prince William Sound region lies within the probable linear extension of the late Mesozoic petrographic and metallogenetic provinces of the Pacific coast of North America, that the ore deposits of the Prince William Sound region are similar to those of that province, and that the geologic history of the region is very similar to that of southeastern Alaska and California during late Mesozoic time. This as stated by Spencer, ${ }^{1}$ in a discussion of the possible magmatic origin of the vein-forming waters of southeastern Alaska, was as follows:

(1) Intense folding and metamorphism followed the deposition of strata which paleobotanists agree are either uppermost Jurassic or lowest Cretaceous (Mariposa beds of California); (2) intrusion of granitic rocks (mainly granodiorite and diorite) accompanied the later stages of folding or closely followed the plication and metamorphism; (3) after the intruded rocks had solidified, both they and the inclosing formations were

${ }^{1}$ Spencer, A. C., The magmatic origin of vein-forming waters in southeastern Alaska: Am. Inst. Min. Eng. Trans., vol. 36, pp. 364-365, 1906. 
fractured; (4) the multitude of wounds were healed by the deposition of vein fillings, the minerals of which correspond in almost every respect in the two fields; (5) erosion ensued and was followed by the deposition of formations of Tertiary age.

The Prince William Sound region has had a similar geologic history, except that the age of the sedimentary beds intruded by the granites can not as yet be assigned to a definite horizon in the Mesozoic. From this resemblance alone it would appear reasonable to belieye that the origin of the ore deposits in these regions is identical and that inasmuch as a magmatic origin best explains the genesis of the ore-bearing solutions of southeastern Alaska, British Columbia, and California, a magmatic origin for the metallizing solutions of the Prince William Sound region (including the Ellamar district) should be considered most probable. The presence of albite in the gold quartz veins of the Valdez district and of Kenai Peninsula, of epidote in the quartz veins of the Ellamar district, and of epidote-axinitequartz float in Kenai Peninsula in places where its derivation from near-by ledges was more than probable, is additional evidence in favor of a magmatic source for the ore solutions. Furthermore, the distance of some of the ore bodies of the region from the granitic stocks would seem to militate against the theory that the ore-bearing solutions were meteoric waters heated by the granitic intrusions. The writers believe that the available evidence indicates that magmatic waters were, if not the sole vehicle of introduction of the ores, at least the preponderating one; that the magmas and the ore solutions had a common source; and that the heated aqueous solutions from the deep unconsolidated portions of the magma rose through the cold fractured granitic stocks or through convenient fissures and faults in the overlying sediments, depositing their metallic content along the channels.

\section{SOURCE OF THE COPPER AND OTHER METALS.}

The earlier writers (see pp. 52-61) concluded that the copper deposits of this district were formed either by the concentration of disseminated copper minerals of the greenstones or in connection with the intrusion of basic igneous rocks. To the present writers an apparently more probable hypothesis.is that the metallic ore minerals, chalcopyrite, pyrite, pyrrhotite, sphalerite, galena, arsenopyrite, gold, and silver, were introduced by magmatic waters, following the intrusions of the Mesozoic granitic rocks, and that the ultimate source of the metallic content of these minerals was in these igneous rocks. Emphasis has been laid by the earlier writers on the copper content of these ores without any consideration of the facts that many other metals were introduced into the rocks at the same time as the copper and that any adequate explanation of the source of the copper must embrace also the other intimately associated metals-iron, zinc, lead, arsenic, gold, and silver. Were the copper derived from the green- 
stone by chemical activity during the shearing, aided by a moderate supply of rock moisture, it would naturally follow that the other metals were derived from the greenstone also during this metamorphism. Sheared greenstones occur in the Prince William Sound region, however, without associated copper or other mineral deposits. Moreover, the development of the schistosity in the ores is shown under the microscope to be definitely earlier than the metallization. This later introduction of the ore minerals was presumably, as has been shown, by heated alkaline solutions.

The possibility exists that these heated alkaline solutions leached the metallic mineral content from the greenstones and concentrated it in the present ore bodies. The adequacy of this leaching process to perform this operation under deep-seated conditions; granting a sufficient metallic content in the rock, is questioned by the writers. Serious doubts have been cast upon its efficacy in general by recent writers, principally Kemp. It is believed that undue importance is attached to the possibility of the formation of ore bodies of the types under consideration by this process of leaching. With well-defined channels open for the passage of the metallizing solutions, it does not appear that they would penetrate the massive country rock in sufficient quantities to abstract any large portion of its metallic content. The leaching process, moreover, fails to account for those ore deposits that are in no way associated with the greenstones, and some of which are thousands of feet away. No original copper-bearing minerals have been observed in the unaltered greenstones of the area or in the much altered greenstones away from the ore deposits. This is true of other regions also. Chemical analysis shows a small copper content in most basic igneous rocks, but as petrographic search fails to show it the usual presumption is that the mineral is present as a copper silicate. Microscopic evidence in all ore and greenstone sections examined in the Ellamar district indicates an introduction of the ore minerals into the rock mass, and not a transference from one place to another within the rock mass.

The marked association of most of the sulphide ore deposits with the greenstone appears best explained by the more ready replaceability of the crushed filling of the greenstone shear zones; and in some places the involved interbedded limestones, than that of most of the sedimentary beds. Impure limestone strata occur in the Orca group but are comparatively scarce, and at only a few places have they been favorably situated for mineralization, whereas the greater abundance of greenstone offered relatively greater opportunity for deformation and subsequent mineralization.

The assumption has been made that the ore-bearing solutions were magmatic waters which derived their metallic content from igneous $\$ 6673^{\circ}-$ Bull. $605-15--6$ 
intrusive rocks. Grant, in his reports, suggested a possible connection with basic intrusives, which he considered as possibly later than the deformation of the area, but he failed to show any direct connection between these basic rocks and the ore deposits. Work in the Ellamar district has not shown any basic intrusives later than the greenstones. In the entire Prince William Sound region no basic igneous intrusive rocks are known of later age than the intrusion of the granites which preceded the mineralization and from which, therefore, the magmatic waters were probably derived as well as their metallic contents.

\section{TIME OF METALLIZATION.}

The metallization of the rocks of the Ellamar district took place subsequent to the folding and faulting of the sedimentary rocks and associated lava flows. There was but one period of metallization. From the analogy of the conditions here to those in other parts of the Prince William Sound region, it is seen that this metallization took place slightly later than the intrusion of the granites of Prince William Sound. The age of these granites of Prince William Sound is not definitely known. In some places they intrude Orca rocks (presumably of early Mesozoic age) and are therefore younger than those rocks. The nearest large granitic intrusions whose age has been fairly definitely determined lie in the Iliamna and Talkeetna regions. Martin and Katz ${ }^{1}$ have concluded that the granites of southwestern Alaska are all pre-Upper Jurassic in age, and Paige and Knopf ${ }^{2}$ regard the quartz diorites of the Talkeetna Mountains and upper Matanuska Valley as of Middle Jurassic age. If the granitic intrusions of Prince William Sound can be correlated with the other granitic intrusions of southwestern Alaska, which appears likely, they are also probably of Mesozoic age. Brooks ${ }^{3}$ states the matter as follows:

The genesis of most of the Alaskan ore bodies is more or less directly traceable to the influence of intrusions which took place during Mesozoic time. During this period of intrusion probably most of Alaska south of the Endicott Mountains was injected by igneous rocks. The intrusions began in early Jurassic time, possibly in some parts of the region in Triassic or even in late Paleozoic time, and culminated during Lower Cretaceous time but continued in some places into the Upper Cretaceous. This epoch of volcanism followed and accompanied crustal movements which were continental in their effect and as a result of which many of the main structural lines were established.

The great batholiths of the Coast Range of southeastern Alaska were probably intruded during: Jurassic and Cretaceous time. The northwesterly extension of this same belt of intrusive rocks carries them into the Alaska Range, where large stocks of igneous rocks are common. All these intrusive rocks show the same lithologic facies,

1 Martin, G. C., and Katz, F. J., A geologic reconnaissance of the Iliamna region, Alaska: U. S. Geol. Survey Bull. 485, p. 77, 1912.

${ }^{2}$ Paige, Sidney, and Knopf, Adolph, Geologic reconnaissance in the Matanuska and Talkeetna basins, Alaska: U. S. Geol. Survey Bull. 327, p. 20, 1907.

${ }^{3}$ Brooks, A. H., Geologic features of Alaskan metalliferous lodes: U. S. Geol. Survey Bull. 480, p. 57, 1911. 
ranging from granites to diorites in composition. Rocks of the same varieties and of approximately the same age of intrusion are found in the batholiths of the Talkeetna Mountains, north of Cook Inlet.

It appears altogether probable that the granitic intrusives of Prince William Sound and vicinity are smaller stocks-offshoots of this same great Mesozoic batholith.

It will be shown below that the metallization followed these intrusions. Further, none of the known Tertiary rocks of this part of Alaska show the characteristic type of mineralization exhibited by the rocks of Prince William Sound. This would seem to restrict the mineralizing period to that portion of the Mesozoic era between the intrusion of the granites and the beginning of Tertiary time, and since a close relationship exists in general between intrusives and ore deposits it is probable that the mineralization closely followed the granitic intrusions.

\section{RELATION OF THE ORE DEPOSITS TO INTRUSIVE ROCKS.}

The field work of 1912 suggested that the mineralizing solutions were of magmatic origin and probably circulated shortly after the intrusion of the granitic rocks of the Prince William Sound region. The writers were unable to substantiate this suggestion that season on account of the small portion of the Prince William Sound region examined and the lack of granitic intrusives closely associated with the ore deposits of the Ellamar district. In 1913 B. L. Johnson, during reconnaissance work in other parts of the Prince William Sound region, obtained definite proof that the metallization is later than the granite intrusions.

It should be emphasized here that the Ellamar district is but a small portion of the much larger Prince William Sound mineral belt and that, so far as present investigations have been carried on, the genetic relations of the ore deposits were practically identical throughout this whole belt. General conclusions drawn from the study of the district as a whole should therefore, if correct, be applicable to any of the smaller districts, in any one of which certain necessary steps in the genetic history of the ore deposits may appear to be lacking.

Numerous small bodies of granitic material, conveniently referred to as subordinate or "cupola" stocks of an underlying granitic batholith, dot the inner or landward shore of Prince William Sound. The character and mode of occurrence of these igneous masses have been described by Grant and Higgins. ${ }^{1}$ One large granitic mass forms the eastern shore of Wells Bay in the northern part of Prince William Sound. On Cedar Bay, an arm of Wells Bay extending up

\footnotetext{
1 Grant, U. S., and Figgins, D. F., Reconnaissance of the geology and mineral resources of Prince William Sound, Alaska: U. S. Geol. Survey Bull. 443, pp. 33-50, 1910.
} 
into this granitic area, an extensive sheeted zone in the granite has suffered later hydrothermal alteration accompanied by the deposition of abundant pyrite, sphalerite, and chalcopyrite.

Numerous acidic dikes are associated with the granitic stocks of the Prince William Sound region. Certain of these dikes in the Port Wells and Seward-Sunrise districts have been fractured and mineralized subsequent to their intrusion. Similar conditions probably exist in other parts of the Prince William Sound. A granitic stock cut by gold-bearing quartz veins is reported. in one of the nunataks of the Columbia Glacier.

It has already been suggested that the gold and copper deposits of the Prince William Sound region presumably had a common origin and that within this region but one general period of mineralization has been recognized. It has just been shown that in several parts of the Prince. William Sound region this mineralization took place subsequent to the granitic intrusion. Presumably these conditions held over the entire region and the ores of the Ellamar district are therefore considered to have been deposited at the same time as those in other portions of the sound, and like them subsequent to the intrusion of the granite stocks of Prince William Sound.

RELATION OF THE MINERAL DEPOSITS OF THE ELLAMAR DISTRICT TO METALIOGENETIC EPOCHS AND PROVINCES.

The recurrence of metallogenetic epochs at different periods in the geologic history of the North American continent has been pointed out by Lindgren, ${ }^{1}$ who has subdivided the complex metallogenetic history of the Cordilleran region of North America into seven epochs, namely, (1) pre-Cambrian, (2) early Mesozoic, (3) late Mesozoic, (4) early Tertiary, (5) late Tertiary, (6) post-Pliocene, and (7) Cretaceous or later epochs of copper concentration in sedimentary rocks.

The two Mesozoic epochs are described as follows:

The early Mesozoic epoch.-Sometime during the Triassic an epoch of intense igneous activity began and continued through the Jurassic. Basic lavas, mainly of the types of diabases and andesites, were erupted, largely as volcanic flows, from California to Alaska. A distinct epoch of metallization, principally yielding copper deposits, accompanied or followed these eruptions. We shall not err greatly in ascribing some copper deposits of California and British Columbia to this the second metallogenetic epoch definitely recognized on the Pacific coast.

The late Mesozoic epoch.-The third and most important epoch followed the intrusions of the great batholiths of the Pacific coast to which an early Cretaceous age is generally assigned. These intrusions of intermediate quartz monzonitic or granodioritic character took place upon a scale difficult to grasp in its immensity. The present exposures show two main granitic masses, possibly connected beneath the Tertiary

1 Lindgren, Waldemar, Metallogenetic epochs: Econ. Geology, vol. 4, pp. 409-420, 1909; Canadian Min. Jour., vol. 30, pp. 430-434, 1909; Min. World, vol. 31, pp. 1111-1113, 1909; Canadian Min. Inst. Jour., vol. 12, pp. 102-113,1910. 
lavas. The southern batholith extends through California, the northern batholith stretches from Washington up through British Columbia to Alaska. Another smaller mass now occupies the central part of Idaho. Innumerable intrusives of less volume broke through the crust in southern California, southern Arizona, western Nevada, Oregon, and elsewhere. The age of the batholith of western Montana is somewhat in doubt, it may belong to a later epoch. But throughout this revolution and the birth of the mountain ranges on the coast, the Cretaceous was being quietly deposited at sea level all over the eastern Cordilleran region.

An epoch of intense metallization followed these intrusions within the areas indicated. The great interior masses of the batholiths are usually free from deposits, as shown in the high Sierra, in the Clearwater region, and in British Columbia. But along their margins mineral deposits formed in abundance, as along the gold belt of California, and along the two contacts of the batholith of the Canadian and Alaskan coast regions. The latest researches by the Alaskan division of the United States Geological Survey indicate that the great placer fields of Alaska derived their gold from deposits of this epoch. Gold primarily and copper secondarily are the characteristic metals. Along the Pacific const, where there is little limestone in the intruded sediments, lead is practically absent, but in the interior, as in Nevada and Idaho, where the intrusions came in contact with Paleozoic limestone, this metal, with zinc, begins to appear. Silver is everywhere present, but scarcely ever important, except where lead appears. Arsenic and antimony are not abundant. Mercury is nowhere present in commercial quantities.

The broader relationships of the Alaskan metalliferous deposits have been discussed by Brooks ${ }^{1}$ and more recently briefly referred to by Butler. ${ }^{2}$

Brooks has shown that many of the metalliferous deposits of Alaska are of Mesozoic age. He also says: ${ }^{3}$

The time of most intense and widespread metallization can probably be still further limited to the Jurassic or Cretaceous and was thus synchronous with the mineralization which produced the valuable deposits of California and other parts of the western Cordillera. Therefore most of Alaska's metallic deposits belong to the same metallogenetic province as those of the western United States.

\section{He further states: ${ }^{4}$}

The gold and copper deposits of southeastern Alaska and of the Iliamna region, the gold deposits of the Nizina, Yukon-Tanana, Chistochina, Yentna, Willow Creek, Koyukuk-Chandalar, Innoko-Iditarod, and possibly those of Prince William Sound and Kenai Peninsula, all appear to be genetically related to the Mesozoic intrusive rocks.

The association of the cupriferous deposits of Prince William Sound with greenstones and sediments of the Orca group is noted, but the statement is made in regard to these occurrences as well as certain others that "none of these deposits are known to have such marked association with intrusive rocks as has been noted in the

\footnotetext{
1. Brooks, A. H., Geologic features of Alaskan metalliferous lodes: U. S. Geol. Survey Bull. 480, pp. 4393, 1911.

2 Butler, B. S., Copper: U. S. Geol. Survey Mineral Resources, 1911, pt. 1, pp. 259, 260, 1912; idem, 1912, pt. 1; pp. 279, 281, 1913.

3 Brooks, A. H., op. cit., p. 56.

${ }_{4}^{4}$ Idem, p. 58.
} 
metalliferous veins of southeastern Alaska." 1 Under a discussion of the copper deposits of Alaska, the statement is made ${ }^{2}$ that-

The fourth group of copper deposits comprises those which are associated with greenstones (altered volcanic rocks) and sediments of various types. - These deposits, so far as known, have no direct relation to igneous intrusive rocks, but it is possible that in the deposits of the Prince William Sound type belonging to this group there may be a connection between the genesis of the ores and certain basic intrusive rocks. While definite proof is lacking, it seems probable that the copper of $* * *$ the Prince William Sound $*^{*} *$ deposits was derived from copper minerals disseminated in the associated volcanic rocks.

Butler ${ }^{3}$ in 1912 assigned the Alaskan copper deposits to the period of copper deposition which "occurred in the Mesozoic era, preceding the main deposition of Cretaceous sediments and probably at about the close of the Jurassic or in the early Cretaceous.: These deposits are associated with the great masses of monzonitic and dioritic intrusives."

Later he states" that "some of the deposits included in this group are believed to have been formed early in Mesozoic time."

Though the general characteristics of the ore deposits of the Ellamar district might seem from previous descriptions to fall within the early Mesozoic epoch as defined by Lindgren, it is believed that the data obtained in 1911 to 1913 indicate fairly definitely that the metallization is that of the later Mesozoic epoch. The evidence indicates but one period of mineralization in which both gold and copper deposits were formed, and that these deposits were formed by hydrothermal solutions subsequent to and genetically connected with the Mesozoic granitic intrusions, and consequently were of late Mesozoic age. The ore deposits of the Ellamar district are therefore considered to belong in the late Mesozoic metallogenetic epoch as defined by Lindgren, and to be a part of the late Mesozoic metallogenetic province of which gold and copper are the characteristic metals, associated with the petrographic province characterized by the intermediate quartz monzonite or granodiorite magmas of the great batholith of the Pacific coast, the intrusion of which in late Mesozoic time was immediately followed by intense metallization along its borders. These ore deposits of the Ellamar district appear to correspond, therefore, in both age and genetic relations, with many of Alaska's gold-lode deposits and with certain of the copper deposits, and to belong to the same metallogenetic epoch and province as those of the western coast of the United States.

\footnotetext{
1 Brooks, A. H., op. cit., p. 47.

2 Idem, p. 80.

${ }^{3}$ Butler, B. S., Copper: U. S. Geol. Survey Mineral Resources, 1911, pt. 1, pp. 258-259, 1912.

4 Butler, B. S., Copper: U. S. Geol. Survey Mineral Resources, 1912, pt. 1, p. 279, 1913.
} 


\section{MINES AND PROSPECTS OF ELLAMAR DISTRICT.}

Comparatively little development work has been done in the Ellamar district, except at the mines now producing, since the region was visited by Grant and Higgins in $1909 .{ }^{1}$

The writers are indebted to Mr. L. L. Middelkamp, Mr. W. A. Dickey, and Mr. W. A. Rystrom for information furnished and for permission to examine the workings of the mines of the Ellamar Mining Co., Threeman Mining Co., and Landlock Bay Copper Mining Co., respectively. The writers' thanks are also due to Messrs. Peter Steinmetz, Guy Banta, W. B. Hancock, and George Walentine, who acted as guides and furnished considerable information regarding the prospects, and to Mr. Charles Simenstad, who supplied much information regarding the Galena Bay prospects. The mines of the district are chiefly copper producers, although gold and silver are present in the ores, and in recent years the Ellamar mine has been shipping ore with a considerable gold content. Most of the prospects were located for copper, but a few are on gold quartz lodes. The absence of anyone familiar with the underground development at many of the prospects prevented as complete a study of the deposits as might otherwise have been possible. The producing mines are arranged in order of their present importance as producers. The prospects are described as nearly in geographic order from north to south as is possible. The length of descriptions bears no relation whatever to the relative values of the different prospects.

Most of the economic studies were made in 1912, but some additional notes on the larger operations in the district were obtained in. the following year. Therefore the mining developments here recorded for the most part represent the status of affairs in the district at the close of $1913 .^{2}$

\section{COPPER MINES.}

ELLAMAR MINE.

Location.-The Ellamar mine is situated at the town of Ellamar, on the east shore of Virgin Bay (see Pl. I, in pocket), about 20 miles southwest of Valdez. The ore body outcrops on the beach between high and low tide marks. The workings are on the Copper King and Gladhaugh claims, and the original discovery was on the end line between these two claims, which were staked along the lead. (See Pl. X, A.)

History and development.-The Gladhaugh and Copper King claims were located early in 1897 by M. O. Gladhaugh and C. Peterson. The first shipment of ore, blasted from the outcrop of the ore body,

\footnotetext{
1 Grant, U. S., and Higgins, D. F., Reconnaissance of the geology and mineral resources of Prince William Sound, Alaska: U. S. Geol. Survey Bull, 443, 1910.

2 The developments in the district are recorded in the reports issued annually on the investigations of the mineral resources of Alaska.
} 
was made late in the fall of 1900 on the steamer Bertha. Two hundred and forty-eight tons of this shipment was smelted at Tacoma, Wash. The sinking of the shaft was started in the summer of that year, about 150 feet landward from the outcrop of the ore body. The following year the Ellamar Mining Co. was formed. In 1902 a crosscut was driven from the shaft and the ore body was struck on the 100-foot level. In 1905 the shaft had reached a depth of 500 feet and the 500-foot level had been opened, but the ore body had not been struck on that level. In the two following years development work was in progress on the 500 and 600 foot levels and ore was found on the 500-foot level. As the ore body was not found on the 600 -foot level a raise was started and an intermediate level driven at 530 feet. In September, 1907, the lower end of the ore body was found on this intermediate level. The cofferdam was started in 1909 to exclude the tides from the outcrop of the ore body, so that the portion of the ore body between the 100-foot level and the surface could be removed. In 1910 the cofferdam was completed, and between 1910 and 1913 mining was confined to that portion of the ore body between the 200-foot level and the surface. In 1912 the lower levels were flooded and the water stood several feet deep on the station at the 400-foot level. In 1913 the 400-foot level was unwatered. Development in that year was confined to the 200, 300 ; and 400 foot levels and the stopes between these levels. The earlier development was confined to the removal of a rich copper shoot. In recent years other portions of the deposit have been found to yield pay ore, containing gold as well as copper, and at present the entire sulphide deposit, of which the rich copper shoot formed a small part, is being mined as ore.

The underground workings at present comprise a large glory hole, a 600-foot three-compartment vertical shaft, about 4,000 feet of drifts and crosscuts on eight levels, and stopes between several of the levels. The mine has been a regular producer since 1900.

Equipment.-One 200-horsepower Geary water-tube boiler, fired with crude oil, handles all the work at the mine at present, but two 70-horsepower Brownwell tubular boilers are being installed. These will also be fired with oil. The plant when completed will have available about double the necessary horsepower. A 1,200-foot two-stage compound Nordberg air compressor, operating condensing, installed in the spring of 1913, furnishes air for all undergr.vund work-drilling machines, mine pumps, and diamond drill. One 8 by 24 by $12 \frac{3}{4}$ inch Nordberg steam air compressor installed in the fall of 1912 furnishes air for operating the air lift, which pumps the seepage water from the cofferdam sump. A steam hoist is used for 


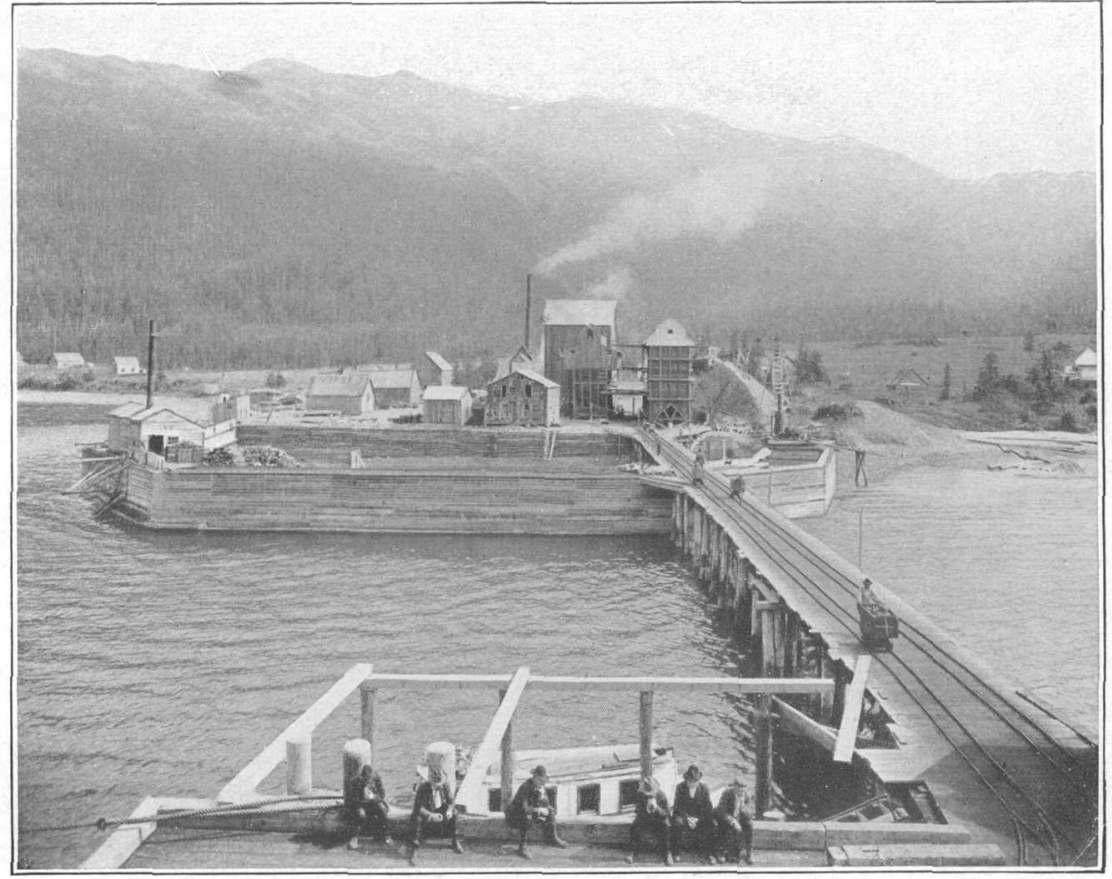

A. ELLAMAR Mine.

The workings are inclosed by a cofferdam.

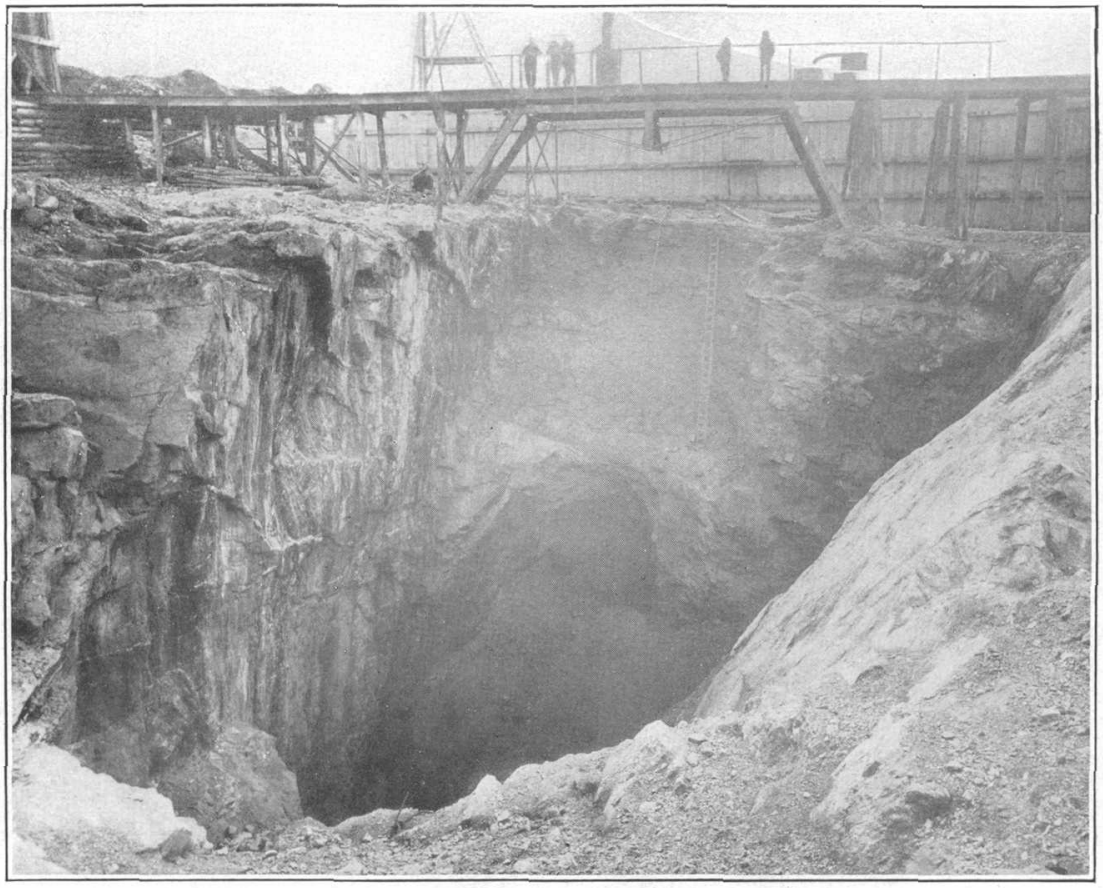

B. ORE BODY OF ELLAMAR MINE, EXPOSED IN GLORY HOLE WITHIN COFFERDAM.

From a photograph by E. A. Hegg. 
hoisting ore and men from the mine and for lowering the men to work.

The plant is electric lighted, a 6-kilowatt generator belted to the small compressor furnishing the lighting current. A 400-foot Rand steam-driven compressor is held for emergency use. A small steam engine furnishes auxiliary service in the machine shop, blacksmith shop, etc. The mine buildings include superintendent's house, assayer's house, store, office building, assay laboratory, mess house, bunk houses, machine shop, blacksmith shop, shaft house, compressor house, ore bunkers of 2,200 tons capacity, and oil tanks. A 28-room bunk house, capable of housing 56 men, was erected.in 1913. A small wireless plant was also installed in that year. A large wharf

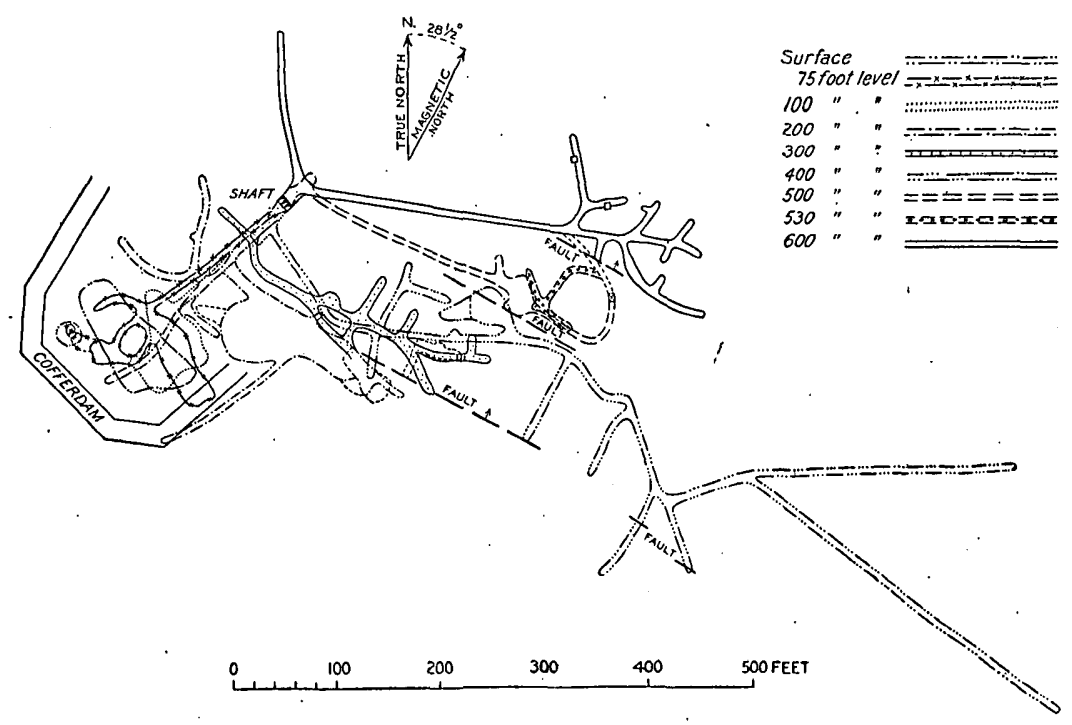

FIGURE 6.-Plan of underground workings of Ellamar mine.

extends from the ore bunkers across the glory hole and out into the bay. In 1913 an inclined skipway'was erected at the end of the wharf and ore loaded direct to steamers, doing away with the old method of pushing cars from the ore bunkers to the ships. An average of 40 men were employed about the property in 1913.

Method of mining and ore treatment.-The first stoping method used was that of shrinkage with ample pillars at the levels. After these stopes were finished and the ore pulled, considerable ore was found here and there on the sides of these old stopes and it was taken out in whatsoever way or manner presented itself to the man in charge. In the summer of 1913 the method of mining the ore was changed and the filling system was started. All the ore from the slate hanging wall to the slate footwall is mined, and mucked into 
chutes. The chutes and manways are run up to within working distance of the ore and the stopes filled with slate secured by running waste raises into both foot and hanging walls. The ore is trammed by man power to the shaft, raised by steam hoist, partly hand sorted, stored in the ore bunkers, and finally shipped to the Tacoma smelter.

Geology of ore body.-The ore body of the Ellamar mine lies within the lower series of slate and graywackes of the Orca group (see Pl. $\mathrm{X}, B)$, the lithologic characteristics of which are described on page 88. Bedrock outcrops are scarce near the ore body. To the north, south, and east lie till-covered flats and to the west Virgin Bay. Along the shore at low tide a few outcrops are exposed between the mine and the mouth of Gladhaugh Creek. These outcrops consist, at the northern end, of interbedded slates and graywackes-thinbedded black slates with a few thin intercalated graywacke beds up to 2 inches thick, from 1 inch to 8 inches apart. One graywacke bed has a thickness of about 18 inches. The strike of the bedding here was N. $60^{\circ} \mathrm{W}$. and the dip was $50^{\circ} \mathrm{E}$. At a point about halfway between the above outcrop and the cofferdam the thin-bedded graywackes predominate and the slates are sandy. Here the strike is N. $50^{\circ} \mathrm{W}$. and the dip $75^{\circ} \mathrm{E}$. Similar isolated outcrops occur to a point within 400 feet of the cofferdam. All other known outcrops in the vicinity of the mine are inclosed within the cofferdam, except at extreme low tide, when small additional exposures are visible just outside the cofferdam along the strike of the ore body. 'The country rock inclosed within the cofferdam, and consequently in the immediate vicinity of the ore deposit, consists of interbedded soft black slate, black limestone, dark-colored argillites, and a few beds of finegrained graywacke. The nearest known igneous rocks are the greenstone lava flows north of Gladhaugh Creek, nearly half a mile away. No dikes or igneous rocks, such as are mentioned in the earlier reports (see "Literature," pp. 52-61) as occurring in the immediate vicinity of the mine, were observed by the writers or are known to the present management of the mine.

The strike of the sedimentary beds at the mine is northwesterly, and the dip is about $80^{\circ} \mathrm{NE}$. The rocks were much crushed and sheared by faulting previous to the formation of the ore body. The strike and dip of the shearing are approximately parallel to those of the bedding. A large fault which strikes about S. $60^{\circ} \mathrm{E}$. and dips $55^{\circ}$. NE. has been found below the ore body on the 400 and 500 foot levels. The plane of this fault crosses the plane of the ore body between the 500 and 600 foot levels and is cut again on the 600 -foot level. The upper levels of the mine were not extended westward far enough to intersect the probable upward extension of this fault. Considerable movement has taken place along the sheared zone inclosing the Ellamar ore body subsequent to the ore deposition, 
but apparently has resulted in only slight displacements, slickensiding the ore, and developing joints in the large pyrite lens.

Ore deposit.-The ore deposit is a large lenticular mass of sulphides. The major horizontal axis strikes about N. $35^{\circ} \mathrm{W}$. The ore lens dips $80^{\circ} \mathrm{NE}$. and pitches steeply toward the southeast. The strike and dip of the ore body appear to be the same as those of the bedding of the country rock. The maximum horizontal dimensions of the ore body are on the 200-foot level, where the major axis of the elliptical cross section is about 240 feet and the minor axis about 90 feet in length. The more highly mineralized portion of the outcrop of the ore body measured 80 by 130 feet and is now inclosed by the cofferdam. Less mineralized portions extend outside of the cofferdam along the strike of the ore body. The ore lens is reported to have pinched out between the 500 and 600 foot levels, at 530 feet below sea level.

The ore body consists of two distinct parts-(1) a large lens of solid pyrite, forming the hanging wall for (2) smaller, closely packed parallel lenses, consisting largely of other sulphides. These two parts are separated from each other by a thin but continuous band of black slate, which averages about 2 feet in thickness. Development has not completely outlined the hanging-wall pyrite lens. It outcrops on the surface and is known to extend at least to the 300 -foot level. The maximum thickness of this lens, 35 feet, occurs on the 100-foot level. Its greatest stope length appears to be about 250 feet.

The distribution of the sulphides-chalcopyrite, pyrrhotite, sphalerite, and pyrite--within the second part of the ore body is irregular, and considerable country rock is included in the ore. This portion of the ore body contained the rich chalcopyrite shoot from which has come most of the copper ore mined in the past. In this second part of the ore body southeast of the copper shoot there is a gradual but marked increase in the amount of sphalerite present in the ore, a decrease in the copper content, and an increase in the gold and silver to such an extent that this part of the ore. body is referred to as a gold ore shoot. Most of the ore mined in 1912 came from this shoot. A portion of the hanging-wall pyrite lens was also removed.

The ore.-The metallic minerals in the ore include chalcopyrite, pyrrhotite, pyrite, and sphalerite. Small amounts of galena are probably also present, as lead has been reported in some of the assays. Chalcopyrite is the only copper-bearing mineral in the ore. A close association of sphalerite and gold is. shown in the gold ore shoot, specimens of solid fine-grained sphalerite from which have assayed $\$ 22, \$ 45$, and $\$ 90$ in gold to the ton. The rich copper ore and the hanging-wall pyrite have a very low gold content.

The gangue minerals of the ore body include the country rock, quartz, brownish-black calcite, and white calcite. The black calcite 
is usually marked by fine striations, which are not seen on the later white calcitè.

The order of deposition of the metallic minerals, as determined under a metallographic microscope, was (1) pyrite, (2) pyrrhotite, chalcopyrite, and sphalerite, all later than the pyrite. In most of the polished surfaces of the ore examined these later sulphides appear to have been deposited contemporaneously with one another. One specimen, however, showed tiny veinlets of chalcopyrite with a small amount of sphalerite cutting sphalerite. The black calcite and the pyrite are apparently earlier than the white calcite and the other sulphides. All the sulphide ore minerals were introduced subsequent to the shearing and shattering of the country rock.

Ore genesis.-The Ellamar ore body is the only one of its kind known within the Ellamar district. It has apparently resulted from the sulphide impregnation and replacement of shattered sedimentary strata (some of which were dark-colored limestone) by mineralbearing solutions which probably obtained access to these beds along a faulted zone and deposited the sulphides, impregnating and metasomatically replacing portions of the strata. The pyrite was deposited first, replacing the black calcite, which appears to represent recrystallized limy portions of the original sediments (renascent limestones). The pyrite and black calcite were then shattered. Further replacement of the rocks next took place by mineralizing solutions of slightly different character from those depositing the pyrite. Chalcopyrite, pyrrhotite, and sphalerite were deposited, partly at the expense of the pyrite. White calcite carrying these later sulphides recemented the fractures in the strained black calcite. The hanging-wall pyrite lens maintained its individuality, being but little affected by these later changes in the mineralizing process, although some of the later sulphide-bearing solution penetrated it and deposited its metallic content throughout the interstices of the pyritic mass, partly completing the impregnation and replacement of the original country rock started by the pyrite, and replacing some of the pyrite.

\section{THREEMAN MINING CO.'S MINE.}

Location of property. - The Threeman Mining Co. has a number of claims, locally.known as the Dickey claims, about the head of Landlocked Bay. Most of the development work has been on the north side of the bay, and according to $\mathrm{Mr}$. W. A. Dickey all the present productive workings are on the Keystone claim.

History and development.-The Keystone claim was staked about 1903. The only development on the property at that time was an open cut close to the edge of the bay. After finding prospects there work was started on what is now adit No. 1 and ore was found 
within a few feet of the surface. A shipment of $12 \frac{1}{2}$ tons of ore, assaying a little over 12 per cent copper, from this adit was made in the fall of 1904. The developments in July, 1905, consisted of two 50-foot adits with some short drifts, one 20-foot tunnel, and a few open cuts. Forty-five tons of ore, assaying a little less than 13 per cent copper, are reported to have been shipped in 1906 . Considerable development work was done in the following years, and a few irregular shipments of ore were made. In 1912 the mine was a regular shipper. The underground workings in that year comprised 2,000 feet of adits, drifts, and crosscuts on five levels, at eleva-

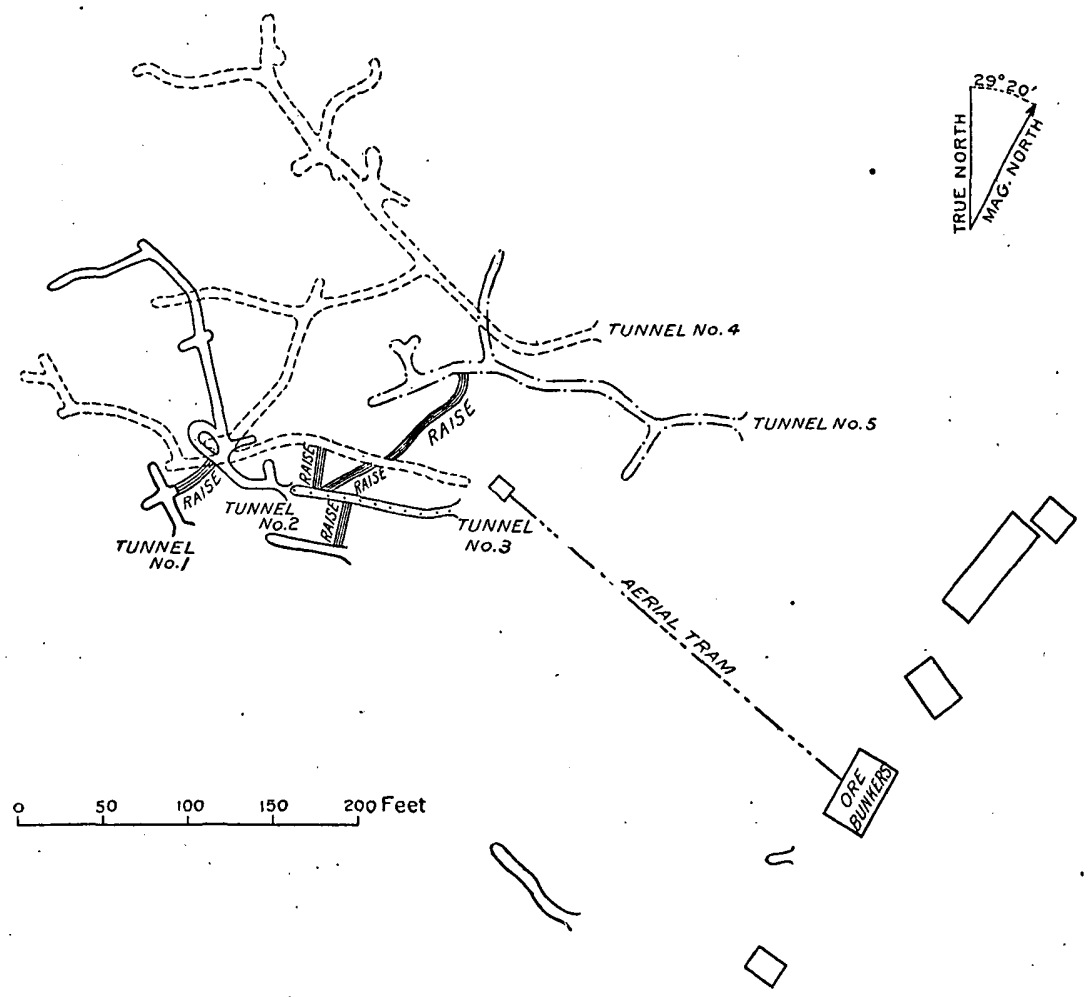

Figuke 7.-Plan of underground workings on Keystone cląim, Threeman Mining Co., Landlock, Alaska.

tions of $282,235,168,122$, and 57 feet above sea level. Considerable stoping was done in a large sulphide ore body opened on levels 3,4 , and 5, and most of the ore shipped in 1912 came from this lens. A little development work was also in progress on the second and fifth levels. No ore shipments were made in 1913, but some underground development work was done.

The extent of the underground development work early in 1912 is shown on the accompanying plan (fig. 7).

Equipment and ore treatment.-No hoisting machinery has been necessary in the underground workings as the property is developed by adit tunnels. Hand drilling only is used in the exploration and 
exploitation of the ore bodies (1913). There are several buildings on the property, including the manager's house, miners' eating and sleeping quarters, ore bunkers, and ore sorting shed. A long wharf was completed in 1911. A short aerial tram extends from the mouth of No. 3 adit to the ore bunkers. The ore after hand sorting is stored in the bunkers until shipped. Shipments in 1912 were to the Tacoma smelter.

Ore deposit.-The country rocks of the ore bodies are the greenstones, graywackes, and slates of the Orca group: The geology is complex on account of the extensive faulting. The trace of the Landlock overthrust fault crosses the head of Landlocked Bay just east of the mine workings, and the rocks west of the fault plane and consequently below it have been intensely shattered, sheared, and faulted. A few of the shear zones are of considerable extent; many are short and narrow. Their strikes differ greatly, but most of them lie within the west-northwest system of fissuring. The dips are steep, $45^{\circ}$ to $90^{\circ}$, and are principally to the north.

Much of the sheared material is mineralized. The ore bodies of workable size and shipping grade, however, are lenticular masses of nearly solid sulphides within the larger shear zones. Recent underground work has been confined to the exploitation of two ore bodies found in two of the larger shear zones. The two upper adits, Nos. 1 and 2, have exposed an ore body in the more northerly zone, and tunnels Nos. 3, 4, and 5 cut one in the southerly zone. These two shear zones are but 20 feet apart on the level of adit No. 2. The northern zone strikes N. $60^{\circ} \mathrm{W}$. and dips $35^{\circ} \mathrm{N}$.; the southern zone strikes $\mathrm{N} .75^{\circ} \mathrm{W}$. and dips $65^{\circ} \mathrm{N}$. The northern shear zone is thought to have been cut in 1912 in adit No. 5, 60 feet north of the other zone.

The dimensions of these ore bodies are not fully known. The width of the northern shear zone is 18 feet at the level of adit No. 1 . The thickness of the ore body ranges from 1 to 6 feet of solid sulphides. The stope length has not been determined, and but 50 feet of the pitch length, that portion between the first and second levels, is known. The continuation of this ore shoot is thought to have been found in the end of tunnel No. 2, 140 feet northwest of the present stopes. Stoping has been confined on this shoot between the second and first levels, and only a small amount of ore has been removed.

The ore body in the southern of these two shear zones ranges from 2 to $9 \frac{1}{2}$ feet in thickness and has been cut on the second, third, fourth, and fifth levels. The present stopes indicate a maximum stope length of about 80 feet. The pitch of the ore body is eastward at an angle slightly greater than the slope of the hill. On the fifth level at an elevation of 57 feet the ore body is 140 feet from the surface; on the third level only 20 feet; and above the third level erosion has removed 
a portion of the eastern edge of the ore body, which extends still farther up the slope. Considerable stoping has been done on this ore body between the fifth level and the surface cropping, and a stope has been started on the second level. A considerable portion of these ore bodies is composed of solid sulphide ore.

The ores are partly replacements by sulphide minerals of the crushed material of the shear zones and partly the cementation of small fractures in the shattered rocks by solid sulphides. Specks of native copper are found in the weathered surface croppings of the lodes. The gangue minerals are quartz, calcite, and the sheared and altered country rocks.

The sulphides in the ore are chalcopyrite, pyrrhotite, sphalerite, and pyrite. A soft pale brass-yellow metallic mineral is intergrown, with the chalcopyrite. This mineral has not been determined, but an analysis was made of a selected sample by $R$. C. Wells in the chemical laboratory of the United States Geological Survey. The ore from which the sample was obtained consists of a mediumgrained intermixture of pyrrhotite, chalcopyrite, sphalerite, galena, and this unknown sulphide. No large pure specimens of any of these sulphides are obtainable. As pure material as could be selected under a high-power microscope was used for this analysis, but on account of the very intimate association of this sulphide with chalcopyrite a very small quantity of chalcopyrite is known to have been included in the sample. The zinc content shown by the analysis is probably due to the presence of a little sphalerite, and the lead content is probably derived from galena, which is known to occur in minute specks in the ores of the district.

Mr. Wells has furnished the following notes on an analysis of this mineral:

The mineral under consideration does not at first sight seem to have a simple formula. It may represent a product of alteration. On the other hand, it appears to be homogeneous, and moreover it is not attacked by dilute hydrochloric acid as is pyrrhotite. If the percentages are converted into atomic values, it appears possible to interpret the mineral as an isomorphous mixture of pyrrhotite and covellite, thus ( $\mathrm{Fe}, \mathrm{Cu}) \mathrm{S}$.

Sulphide from property of Threeman Mining Co.; Landlocked Bay.

\begin{tabular}{|c|c|c|}
\hline . & Analysis. & . $\mathrm{t}$ tomic values. \\
\hline \multirow[t]{2}{*}{$\begin{array}{l}\text { Sulphur (S). } \\
\text { Copper (Cu) } \\
\text { Lead (Pb)... } \\
\text { Iron (Fe)... } \\
\text { Zinc (Zn)... }\end{array}$} & $\begin{array}{r}\text { Per cent. } \\
35.67 \\
16.57 \\
1.30 \\
46.48 \\
.38\end{array}$ & \multirow[t]{2}{*}{$\left.\begin{array}{l}0.261 \\
.006 \\
.832 \\
.006\end{array}\right\} 1.110$} \\
\hline & 100.40 & \\
\hline
\end{tabular}

The question naturally arises whether pyrrhotite and covellite are capable of isomorphous replacement. W. T. Schaller has made a careful examination of the data on this point and concludes that $\mathrm{CuS}$ and FeS are capable of existing in isomorphous mixture. His statement is as follows: 
Pyrrhotite is dimorphous, being hexagonal ( $\beta$-pyrrhotite) and orthorhombic ( $\alpha$-pyrrhotite). The axial ratios for $\alpha$-pyrrhotite, the high temperature form, vary ${ }^{1}$ from $a: b: c=0.5793: 1: 0.9267$ to $0.5793: 1: 0.9927$, the variation in the $c$ axis being due to varying composition of the pyrrhotite (dissolved sulphur?).

Covellite crystals from Serbia were described by Stevanovic ${ }^{2}$ as thin six-sided plates. Goniometric measurements gave very irregular variations, so that the exact " symmetry of the crystals could not be determined. Moreover, a complicated twinning structure made the interpretation of the true symmetry of the mineral almost impossible. Some crystals are hexagonal or rhombohedral, others orthorhombic, and still others either monoclinic or triclinic. Stevanovic decides in favor of the monoclinic system and gives the axial ratio $a: b: c=0.5746: 1: 0.6168, \beta=90^{\circ} 46^{\prime}$. If now the $c$ axis be multiplied by $\frac{3}{2}$-that is, if Stevanovie's form $\{032\}$ be changed to $\{011\}$-then a new axial ratio is obtained which is very close to one of the two values given by Larsen for $\alpha$-pyrrhotite.

$$
\begin{array}{r}
\text { Covellite, } a: b: \frac{3}{2} c=0.5746: 1: 0.9252, \beta=90^{\circ} 46^{\prime} \\
\alpha \text {-Pyrrhotite, } a: b: c=0.5793: 1: 0.9267, \beta=90^{\circ} 00^{\prime} .
\end{array}
$$

The apparent difference in $\beta$ is unimportant, for it has not been proved that covellite is monoclinic or triclinic.

The agreement in crystal form is so very close that an isomorpious mixing of covellite (CuS) with pyrrhotite ( FeS) seems entirely possible.

\section{LANDLOCK BAY COPPER MINING CO.}

Location of property.-The property of the Landlock Bay Copper Mining Co. is situated on the south side of Landlocked Bay, on a narrow greenstone ridge projecting northwestward. into the bay about half a mile southwest of the Threeman mine. The property includes several claims, but the development work has been confined to three of them. The present workings are on the northeast side of the ridge, on the Moonshine claim.

History and development.-The discovery of copper ore on this property was made in 1898. The present owners took hold of the property in 1903, and the Landlock Bay Copper Mining Co. was incorporated in 1906. All the underground development work has been done since 1903, and the present mine workings are reported to have been driven since the incorporation of the company. The present mine workings comprise about 500 feet of drifts, a 25-foot winze, and three short raises. (See fig. 8.) There are three other tunnels on the property that total a little over 400 feet in length.

Equipment and ore treatment.-The mine has been developed by driving an adit 80 feet above sea level and by sinking and raising on the ore bodies from the adit. No hoisting machinery is needed and only hand drilling is used in obtaining the ore. In October, 1912, four men were employed in mining and one in hand sorting the ore. Ore bunkers having a capacity of 800 tons have been built near the mouth of the mine. The living quarters are on level ground close to

${ }_{1}$ Allen, E. T., Crenshaw, J. L., and Johnston, John, The mineral sulphides of iron, with crystallographic study by E. S. Larsen: Am. Jour. Sci., 4th ser., vol. 33, p. 217, 1912.

2 Stevanovié, S., Covellin (Kupferindig) und Enargit von Bor in Servien: Zeitschr. Kryst. Min., vol. 44, p. $349,1908$. 
shore on the southwest side of the ridge. Seven men were employed on the property in 1912. Development work was continued in 1913, but with a smaller force of men.

Ore deposit.-The ore deposit now being developed lies in a shear zone in greenstone, with some interbedded sediments, principally black slate, and a little limestone. A crosscut tunnel was started $\$ 0$ feet above sea level. The lead was cut 180 feet from the mouth of the adit, and 260 feet of drift has been driven along the shear :zone, the strike of which changes from N. $76^{\circ} \mathrm{W}$. in the western 'drift to north at the southeastern end of the present workings. The dip flattens from $65^{\circ} \mathrm{N}$. to $30^{\circ} \mathrm{E}$. along the drift. The width ranges from 4 to 15 feet. Two ore shoots have been found, each of which has a stope length of 25 to 30 feet and a thickness ranging from 1 foot to 7 feet. A 20-foot raise has been driven on one shoot and a 25 -foot winze sunk on the other. The pitch lengths of these shoots have not been determined. Ore from the winze is reported to average at least $7 \frac{1}{2}$ per cent copper. Another 20foot raise was driven in the shear, 25 feet west of the winze, on 10 to 12 inches of ore that is said to assay 4 per cent.

A copper-bearing shear zone on the south side of the ridge, 300 feet above sea level, strikes S. $60^{\circ}$ E. and dips $67^{\circ}$ N. Its width ranges from 2 to 5 feet. The lead is traceable on the surface for some distance east and west of a shaft which has been sunk on the outcrop of the shear zone. The country rock is

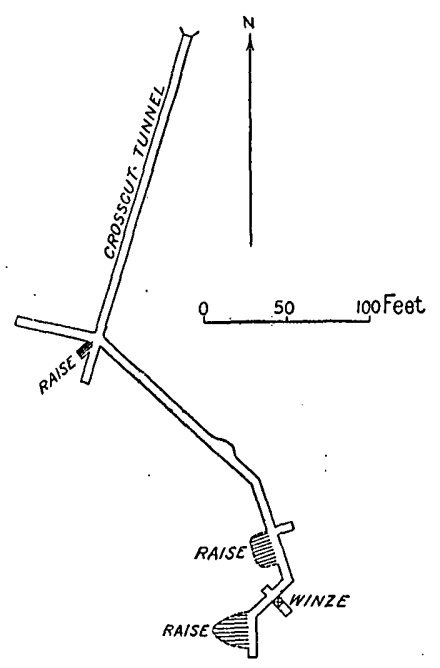

FIGURE 8.-Sketch plan of main underground workings of Landlock Bay Copper Mining Co. (1913). greenstone and hard blocky slates. The ore occurs in masses. A crosscut tunnel has been started northward from a lower elevation on the hill slope to intersect this lead. Other undeveloped mineralized shear zones are reported on the property.

The ores are chiefly replacements by sulphide minerals of the crushed material of the shear zones. To a much less extent the sulphides fill small fractures in shattered black slate. The sulphides include chalcopyrite, pyrrhotite, sphalerite, and a few specks of an undetermined sulphide resembling the sulphide found at the Threeman mine. The gangue includes quartz, calcite, slate, and greenstone. Much of the calcite has a fine white sugary appearance. It is possibly a recrystallized limestone that was originally interbedded with the other sediments and the greenstone.

$$
86673^{\circ}-B 111.605-15-7
$$




\section{COPPER PROSPECTS.}

\section{BANTA \& OAMERON PROSPECT.}

The Mogul group, the property of Guy Banta and Fred Cameron, is situated on the east side of the gap between Boulder and Galena bays, about $1 \frac{3}{4}$ miles from the head of Galena Bay at an elevation of 1,600 feet above sea level. The development work in September, 1913, consisted of a shaft 10 feet deep and several open cuts. The ore occurs in shattered and sheared greenstone in irregular masses. Considerable quartz shows as a fine irregular network on weathered surfaces. The ore minerals include chalcopyrite, pyrite, pyrrhotite, and sphalerite.

\section{FIELDER \& HEMPLE PROSPECT.}

The Fielder \& Hemple prospect is situated at the northeast salient of Boulder Bay, a short distance northeast of the Boulder Bay property of the Reynolds Alaska Development Co. The lower and longer tunnel is at an elevation of 350 feet above sea level.

The development work consists of two adits and some surface stripping. The lower tunnel, which has 260 feet of drifts and a 25-foot raise, was driven to intersect a shear zone which outcrops about 100 feet above the tunnel mouth. The upper tunnel, 20 feet long, at an elevation approximating 450 feet above sea level, is driven along the shear zone.

The country rock at the lower adit is greenstone with some hard black slate, fractures in which are filled with quartz. No well-defined shear zone or ore body was seen in this tunnel. At the adit tunnel the country rock appears to be all greenstone. The ore deposit consists of a poorly mineralized shear zone lying at the foot of an overhanging ellipsoidal greenstone bluff. This shear zone strikes N. $45^{\circ}$ E., dips $65^{\circ} \mathrm{N}$., and is from 25 to 30 feet wide. The shearing is poorly developed. The ore occurs in small masses, of which the largest seen was 10 inches thick, and consists of much fine-grained pyrite with only. a little chalcopyrite, pyrrhotite, and quartz.

\section{PROSPECTS OF GALENA BAY MINING CO.}

Location.-The prospects of the Galena Bay Mining Co. are situated on the north slope of Copper Mountain near the head of Vesuvius Valley. They are about 3 miles in an air line south of the head of Galena Bay.

History and development.-The early history of this property is summarized by Mr. Chas. Simenstad, ${ }^{1}$ one of the original locators:

The original discovery of the ground which now constitutes the property of the Galena Bay Mining Co. was made in the month of October, 1899, by A. M. Hendrie and 
myself, during which year only one location was made, namely, the Minnehaha No. 2 . The following'year three more locations were made and during the months of September and October, 1901, the balance of 21 locations were made, all by the same locators. Assessment work was the only work attempted up to May, 1903, when we gave an option to purchase to the Prince William Sound Mining Co., whose headquarters were Los Angeles, Cal.

During the summers of 1903 and 1904 this company constructed a pack trail from the head of Galena Bay to the properties, with a storehouse and barn at the bay and cook-

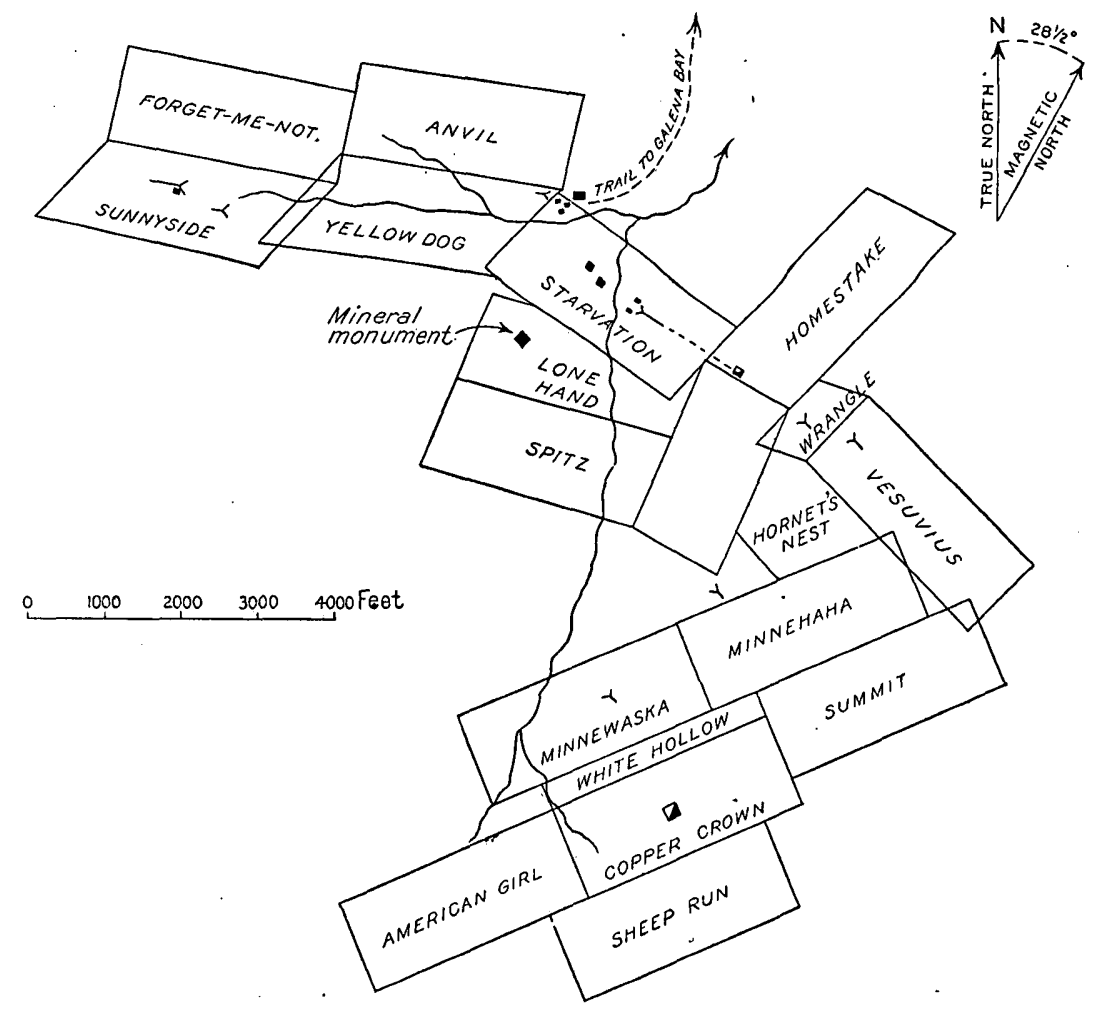

Figure 9.-Claim map of property of Galena Bay Mining Co. in Vesuvius Valley.

house and workhouse at the properties. Two cabins at the property had previously been constructed by Hendrie and myself.

This company also drove about 300 feet of tunnel on the Starvation claim, the ore zone on the Vesuvius claim being the objective point, sunk a shaft 6 feet in depth on the Copper Crown ore body, and drove a 20 -foot tunnel on the Minnewaska claim.

Prince William Sound Mining Co. forfeited their option and during the year of 1905 Hendrie and myself, owners, did the assessment work.

In the month of November, 1905, we gave an option to purchase to the Galena Bay Mining Co., a Washington corporation, to which company the title to the claims as shown on the map was transferred in 1909, and which company is the present owner.

The long adit, started on the Starvation claim, has since been extended to a length of about 2,200 feet. Several shorter adits have been driven on the various claims. Four hundred feet of adit, a shaft 47 feet in depth, and numerous open cuts constitute the development 
work on the Sunnyside claim. Some stripping and open-cut work have also been done on the Sheep Run and Copper Crown claims. Considerable diamond drilling has been done by the Galena Bay Mining Co. In 1912 and 1913 only assessment work was done.

Equipment.-Considerable money has been expended in the development of this property. Several buildings, including.four dwellings, a bunkhouse, and a storehouse, have been erected on the shore at the head of Galena Bay. Bottle Creek has been dammed three-fourths of a-mile from its mouth and gives a 52 -foot head of water. A turbine and generator installed here at the dam furnished electric current, which was transmitted to the mine where it operated motor-driven 1-drill and 2-drill air compressors and lighted the camps. Other equipment includes a large fan for ventilating purposes, two gasoline engines, one electric-driven Sullivan diamond drill, machine drills, steel mining tools, and machine and blacksmith shops. Seven buildings have been erected at the mine camp. Material for an aerial tramway 3 miles in length, from the mine to the head of Galena Bay, is on the ground, but the tramway has not been erected. A road connects the ore camp with the power house and mine, and a telephone system is in operation between these three places:

Ore deposits.-The claims of the Galena Bay Mining Co. lie within the sheared and shattered zone, here composed principally of greenstone, which borders to the westward the trace of the Landlock overthrust fault. The principal ore bodies are on the Vesuvius, Sunnyside, Copper Crown, and Sheep Run claims. The country rock is predominantly greenstone, with some graywacke and slate. The greenstone is ellipsoidal in places.

The 2,200-foot crosscut tunnel was started on the Starvation claim, north of and beneath the shear zone on the Vesuvius claim, which it was intended to intersect and which outcrops on the east side of the valley. The adit was started on a small iron-stained shear zone carrying a few small stringers of chalcopyrite, pyrrhotite, pyrite, and quartz. About 1,700 feet from the mouth the tunnel forks. The right branch was driven forward until a wet strip (possibly the Vesuvius shear zone) was reached. The left branch was swung a little to the north and was then continued for 500 feet. At the end it separates into three branches, each about 50 feet in length. The main shear zone was not recognized in the adit.

On the surface the Vesuvius shear zone passes between the mouth of the crosscut tunnel and the steep rock bluff a short distance to the south. To the west it heads for the low saddle on the Sunnyside claim. To the east it extends up the steep east wall of the valley toward the Landlock overthrust fault. At an elevation of 1,060 feet a 15-foot adit has been driven on a poorly developed shear zone which strikes $\mathrm{N}$. $75^{\circ} \mathrm{W}$., dips $60^{\circ} \mathrm{N}$., and contains a few lenses 
of chalcopyrite, pyrrhotite, quartz, and calcite, 4 to 5 feet in length and up to 14 inches in width. At 1,180 feet a 20 -foot tunnel has a long, narrow epidote-bearing quartz vein in the face but contains no ore. At 1,400 feet a 15 -foot adit is driven on the Vesuvius shear zone and the ore which has thus far been found on this claim is said to have been found in this adit and above it. The shear zone is about 20 feet wide; strikes N. $50^{\circ} \mathrm{W}$., and dips steeply to the south. Some ore is found in this adit but no solid masses of sulphides. At an elevation of 1,450 feet the shear zone splits. The south fork strikes N. $30^{\circ}$ W. and dips vertically. The north fork strikes N. $50^{\circ} \mathrm{W}$. and dips $70^{\circ} \mathrm{S}$. The shear zone has a width of 12 feet at 1,500 feet elevation and is heavily iron stained. Quartz, calcite, pyrrhotite, and chalcopyrite occur in narrow irregular stringers in the sheared and shattered greenstones and slates. The principal sulphide is pyrrhotite.

The lead on the Copper Crown claim is located at an elevation of 2,250 feet on the east wall of the cirque at the head of the valley. Where the lead is best developed, 4 feet of solid sulphide ore is contained in a shear zone that strikes N. $75^{\circ} \mathrm{E}$. and dips $80^{\circ} \mathrm{S}$. The country rock is massive unsheared greenstone. The width of the shear zone ranges from 3 inches to over 4 feet. The mineral content also varies and in places there are only a few narrow stringers of sulphides. The shear zone is traceable to the northeast about 250 feet and then appears to pinch out. In this portion the lead changes to a fairly well defined quartz vein carrying small amounts of sulphides and reported to assay from $\$ 3$ to $\$ 4$ a ton in gold. The quartz is frozen to the walls. An open cut has also been made on the shear zone 200 feet southwest of the 4 -foot sulphide open cut referred to above. Here the lead strikes N. $65^{\circ} \mathrm{W}$. and dips $75^{\circ} \mathrm{N}$. The width ranges from 2 to 5 feet and some good ore is exposed. The walls are sheared ellipsoidal greenstone. Average assays of 12 per cent copper are reported on ore from this shear zone, but so far the only development work has consisted of a few open cuts.

The exposure of the ore on the Sheep Run claim is at an elevation of about 2,480 feet on the east side of the valley. About 30 feet of the outcrop is exposed along the strike of the lead. The maximum width of the lead is about 8 feet. The country rock is greenstone, which in the bluffeast and above the ore body shows well-developed ellipsoidal structure. The shear zone strikes N. $60^{\circ} \mathrm{E}$. and dips $55^{\circ}$ SE. The hanging wall is sharply defined, but the footwall is indefinite. Considerable quartz is associated with the ore. The only development is a little open-cut work.

The Sunnyside claim is located. on the ridge west of the cabins. The country rock is principally greenstone, much shattered, cemented by a fine network of quartz veinlets, and extensively mineralized. 
Numerous small shear zones have different strikes, but most of them lie within the east-west system of fissuring. No large continuous shear zones have been found. The distribution of the mineralization is irregular and bunchy. A 28 -foot adit has been driven at an elevation of 1,550 feet on a shear zone that strikes S. $70^{\circ} \mathrm{E}$. The ore is principally pyrrhotite with small amounts of chalcopyrite in the sheared and shattered greenstones. The upper and longer adit, which has about 400 feet of drifts and two winzes, is at an elevation of 1,700 feet. Two ore bodies, containing ore said to average as high as 12 to 14 per cent copper, were struck in this adit. A shallow shaft on the crest of the ridge, which is sunk on a 5 -foot shear zone that strikes N. $10^{\circ}$ W. and dips $85^{\circ}$ E., contains a 20 -foot lens, 8 inches wide in places, of solid sulphides.

The ores, with the exception of a portion of the Copper Crown lead, are believed to be partly replacements of the sheared and shattered greenstones and partly the filling of tiny fractures in the shattered rocks by solid sulphides, comprising chalcopyrite, pyrrhotite, pyrite, and sphalerite. The gangue minerals are quartz, calcite, and the sheared and altered country rock. A portion of the Copper Crown lead is plainly the filling of an open fissure by a siliceous sulphidebearing solution. The sulphides deposited in this portion of the lead are the same as those in the replaced portions.

\section{PROSPECTS OF REYNOLDS ALASKA DEVELOPMENT CO.}

The Landlocked Bay property of the Reynolds Alaska Development Co. is situated near the head of a small northern tributary about a mile from the head of Landlocked Bay.

The first discovery on the property is reported to have been made by Joseph Putz and Peter Steinmetz about 1899. Other claims were located later. The Reynolds Alaska Development Co. was formed in 1903 and is reported to have obtained control of the Landlocked Bay claims in 1904 or 1905 . There is about 900 feet of underground development work on the property at the present time, including two long adits, measuring 600 and 220 feet, respectively, several short adits, open cuts, and a shallow shaft. The surface improvements include a trail from tidewater to the mines, a small warehouse at the bay shore, and a few buildings near the upper workings.

The ore bodies comprise several small shear zones lying close to but a little to the west of the Landlock overthrust fault. The country rock is interbedded greenstone, graywacke, and blue-black slate. At the lower adit, 600 feet above sea level, a shear zone 5 feet in width was cut 60 feet from the portal and a drift was carried 110 feet $\mathrm{N} .35^{\circ} \mathrm{W}$. along the shear, which dips $55^{\circ} \mathrm{N}$. The ore of this shear 
zone is reported to average 5 per cent copper, though some highergrade ore is said to have been obtained in a 6 -foot winze sunk on the lead where the shear zone was first struck in the adit. This shear zone is said to be traceable on the surface for a considerable distance. A shaft 16 feet deep was sunk near the upper cabins in an iron-stained outcrop of much jointed greenstone that contains small patches of chalcopyrite-pyrrhotite ore, 2 inches in maximum thickness, and considerable disseminated sulphides in the more highly shattered portions. A sample taken across 20 feet of this outcrop is said to have averaged 1 per cent of copper.

At an elevation of 845 feet a 600 -foot adit has been driven toward Copper Mountain on an iron-stained shear zone, 3 to 4 feet wide, which has been traced up the slope by open cuts for a short distance. Sixty feet above the adit mouth the shear zone contains 4 feet of solid sulphide ore. No well-defined continuous lead or zone was observed in the adit, although numerous well-defined joints exist. Very little ore was seen. Sulphide stringers, having a maximum thickness of 3 inches and showing more pyrrhotite than chalcopyrite, are found in places, and the sulphides also occur disseminated in the greenstone.

At an elevation of approximately 1,000 feet two short adits, 30 and 35 feet in length, have been driven on parallel leads in greenstone 100 feet apart that strike N. $60^{\circ}$ E. and dip $60^{\circ}$ N. Considerable ore, some of which is reported to average 8 per cent copper, is exposed in the workings. Some of the sulphide lenses are 8 to 10 inches wide.

The ores are believed to be replacements and impregnations of sheared greenstones by the sulphides, chalcopyrite and pyrrhotite. Pyrrhotite is the more abundant. The percentage of chalcopyrite

- present is indicated by the fact that the best assay reported, on picked specimens, showed between 9 and 10 per cent copper. The average copper content of the ore is much less. The gangue material comprises quartz, calcite, and sheared greenstone. Unreplaced fragments of the dark sheared greenstone are scattered through the masses of solid sulphides.

No development work has been done on the property of this company, on Boulder Bay since Grant and Higgins visited it. ${ }^{1}$

PROSPECTS OF L. P. M. FALCK.

The claims belonging to L. P. M. Falck are situated on the east slope of Copper Mountain a short distance west of the Landlocked Bay property of the Reynolds Alaska Development Co. The claims,

1 Grant, U. S., and Higgins, D. F., Reconnaissance of the geology and mineral resources of Prince William Sound, Alaska: U. S. Geol. Survey Bull. 443, p. 61, 1910. 
reported to be 6 in number, were located about 1900. Only assessment work has been done on them. The developments include a 25-foot adit at an elevation of about 1,100 feet and numerous open cuts. Several leads are reported on the property. The highest showing is said to be at an elevation of about 1,600 feet above sea level.

The country rock of the ore bodies is principally greenstone, but considerable black slate and a little graywacke are usually associated with the ore deposits. The 25 -foot tunnel is driven in greenstone with associated black slate, on a shear zone which strikes N. $70^{\circ} \mathrm{E}$. and dips $83^{\circ} \mathrm{S}$. The width of the shear zone exposed at the adit mouth is about 20 feet. This shear zone is reported to extend for a considerable distance both above and below this adit. The shear zones exposed in open cuts at the points on the claims showed strikes ranging from N. $40^{\circ} \mathrm{E}$. to N. $68^{\circ} \mathrm{E}$., with dips from $70^{\circ} \mathrm{N}$. to vertical. The width of the shearing exposed ranged from 1 to 7 feet. The primary ore minerals include chalcopyrite, pyrrhotite, sphalerite, quartz, and calcite. Thin films of native copper (secondary) are found in the surface showings.

\section{STANDARD COPPER MINES CO.}

The underground workings of the Standard Copper Mines Co. are on the steep south face of Copper Mountain, between 1,400' and 2,100 feet above Landlocked Bay. The present company was organized. in 1906 and most of the development work on the property has been done since that year. The tunnels are connected by an aerial tram with 500-ton ore bunkers on a wharf on Landlocked Bay. Other surface improvements include the manager's house, office, and a large bunkhouse, all in good condition, on the shore of Landlocked Bay, and camp buildings near the upper end of the tram line. A few tons of ore are reported to have been shipped between 1906 and 1911. The property was idle in 1912 and 1913.

The underground workings total about 1,300 feet in length and consist of five tunnels, about $660,290,175,85$, and 28 feet long. A 50 -foot winze has been sunk in the longest adit at a distance of 54 feet from the mouth.

The ore bodies consist of lenticular masses of sulphides of different lengths and widths, and of bunches of sulphides at the intersection of shear zones. The country rock of the shear zones is principally greenstone, but includes some graywacke and black slate. The geology is complex on account of much shearing and faulting. The ore bodies, however, all lie within the greenstone division of the Orca group.

Adit No. 1, driven at an elevation of 1,820 feet, is 175 feet long. Several lines of shearing intersect in the vicinity of this adit, and 
the following bearings have been recorded on these shear zones: Strike N. $90^{\circ} \mathrm{E}$., $\operatorname{dip} 60^{\circ} \mathrm{N}$.; strike north, dip $60^{\circ} \mathrm{W}$.; strike N. $45^{\circ}$ W., dip $65^{\circ} \mathrm{NE}$; ; strike N. $70^{\circ} \mathrm{E}$., $\operatorname{dip} 60^{\circ} \mathrm{N}$.; strike N. $75^{\circ} \mathrm{E}$., dip $35^{\circ} \mathrm{N}$.; strike N. $55^{\circ} \mathrm{E}$., dip $50^{\circ} \mathrm{N}$. Their width ranges from 1 to 20 feet. The linear extent of most of the shear zones is not known. The zone which crosses this adit 30 feet from the mouth and strikes N. $75^{\circ} \mathrm{E}$. and $\operatorname{dips} 35^{\circ} \mathrm{N}$. is traceable on the surface for over 100 feet. A 10-foot raise on this shear zone shows considerable chalcopyrite in the face. In a gulch a short distance east of this adit about $1 \frac{1}{2}$ feet of solid sulphide ore is reported in a 5 -foot shear zone which strikes N. $55^{\circ} \mathrm{E}$. and dips $50^{\circ} \mathrm{N}$. Stringers of mixed chalcopyrite and pyrrhotite that are 1 inch in maximum thickness fill cracks in the overlying ellipsoidal greenstone. Thirty feet farther east this shear zone is much less mineralized.

A short adit, driven at an elevation of 1,800 feet, crosscuts a shear zone about 20 feet wide, possibly the same as the one mentioned above, and is then driven 8 feet along the shearing. This shear zone strikes approximately N. $60^{\circ} \mathrm{E}$. and dips $60^{\circ} \mathrm{N}$.

.Adit No. 2, at an elevation of 2,070 feet, has 660 feet of underground development work. This adit was driven to intersect three ore-bearing zones outcropping on the mountain above. The lowest zone, encountered 45 feet from the mouth of the adit, strikes N. $55^{\circ}$ E. and dips $45^{\circ} \mathrm{N}$. A winze 50 feet deep has been sunk on this lead. Adit No. 4, driven along this same shear zone, crosses adit No. 2 at this point. Several hundred tons of ore, most of which has been shipped, is reported to have been mined from this zone. Two hundred and thirty feet from the adit mouth a 33-foot drift has been driven on a narrow $1 \frac{1}{2}$-foot mineralized shear zone. Three hundred and fifty feet from the mouth a drift has been driven 260 feet S. $60^{\circ} \mathrm{W}$. along a narrow mineralized shear zone, 3 to 6 feet wide, which dips $40^{\circ} \mathrm{N}$. Numerous small quartz-calcite stringers are inclosed in the shear. The ore is reported to assay 4 to 5 per cent copper.

Adit No. 3, at an elevation of 1,450 feet, is 290 feet long. The greenstone at this adit as a whole is massive and not badly sheared. The face is in blocky black slate. A short distance inside of the tunnel a wide shear zone, which strikes N. $40^{\circ}$ W. and dips $60^{\circ} \mathrm{N}$, is crossed. The sheared portions are 2 inches to 2 feet thick and are separated by several feet of solid greenstone. Joints at the mouth of the adit strike N. $15^{\circ} \mathrm{W}$. and $\operatorname{dip} 55^{\circ} \mathrm{W}$. A shear zone 50 feet west of the adit strikes N. $10^{\circ} \mathrm{W}$. and dips $80^{\circ} \mathrm{W}$. Malachite staining is abundant at the mouth of the adit.

Forty-five feet from its mouth adit No. 2 is crossed by adit No. 4, which is driven on a shear zone, 3 to 15 feet in width, that strikes N. $55^{\circ}-80^{\circ}$ W. and dips $60^{\circ} \mathrm{N}$. Adit No. 4 was started in 
a gully 30 feet east of adit No. 2 , which it crosses, extending beyond it about 50 feet to the west. The shear zone is stoped to the surface, except for at least 25 feet. Lenses of sulphides and sheared greenstones lay within the shear zone. The average sulphide content of the entire zone is estimated to be equivalent to a band of solid ore 20 inches thick. The relative proportions of the sulphides vary. The copper content of this ore is not known.

The ores are probably replacements of the crushed filling of the shear zones combined with the cementation of numerous small fractures in the shattered rocks by sulphide minerals, comprising chalcopyrite, pyrrhotite, and sphalerite. The gangue includes calcite, quartz, and the sheared and altered country rock.

\section{HEMPLE COPPER CO.}

The property of the Hemple Copper Co. lies just north of the Threeman Mining Co.'s ground near the head of Landlocked Bay. The company was organized in March, 1910, and its holdings are reported to consist of six claims, all patented, and a 2-acre mill site. The areas included in the claims are timbered. Surface improvements include camp buildings near the lower adits and a good trail to the property from Landlock. There is about 1,350 feet of underground development work, comprising four adits, 800, 450, 65, and 18 feet long, respectively; two shallow shafts, 10 to 15 feet deep; and numerous open cuts. At the lower adit, 450 feet above sea level, a Fairbanks-Morse gasoline engine, belt-connected to a small fan, is used to ventilate the workings. The property was idle when visited in 1912.

The country rock consists of greenstone, black blocky slate, and graywacke. Only one copper lead is reported on the property, a shear zone of irregular width that is said to average 24 feet. Measurements of $5,9,10,15$, and 35 feet were made during the present investigation at different points across the sheared zone, which has been traced by stripping, open cuts, shallow shafts, and adits for over 1,500 feet. The strike of the shear zone changes gradually from N. $55^{\circ} \mathrm{W}$. near its eastern end to the east at its western end. The dip remains constant at about $60^{\circ} \mathrm{N}$.

The distribution of the metal content of the shear zone as a whole is decidedly irregular. Within the more highly mineralized portions the metallic ore minerals are irregularly distributed as stringers, lenses, and bunches of solid sulphides, or are disseminated through the crushed material. Some of the calcite stringers and bunches in the sheared greenstone also carry small amounts of sulphides. Stringers and lenses of pyrrhotite and chalcopyrite 2 to 18 inches thick lie parallel with the shearing, and a few large irregular masses of solid sulphides are found here and there. The entire width of the shear 
zone is mineralized in some places, whereas in others but little evidence of metallization is visible, for instance, at the west end of the lead, where above the 65-foot crosscut tunnel the iron-stained outcrop of the shear zone has been exposed for over 100 feet. At this locality the ore body shows a maximum width of 10 feet at the center, narrowing at both ends, beyond which but little metallization is evident. The mineralized mass shows a lenticular cross section and contains long, narrow lenses and stringers of solid sulphides 1 foot in greatest thickness, irregularly distributed throughout the ore body, as well as considerable quantities of disseminated sulphides.

The ores are probably chiefly replacements by sulphide minerals of the crushed and altered material of the shear zone and fillings of numerous small fractures in the shattered rock by solid sulphides. The sulphide minerals include pyrrhotite, chalcopyrite, and sphalerite. Pyrrhotite is much more abundant than the other sulphides. The gangue minerals are calcite, quartz, and the sheared and altered country rock. Average assays of the mineralized portions of the shear zone are reported to show from 3 to 6 per cent copper. One assay of a sample taken previous to 1905 across a former face of the lower adit showed 6 per cent copper, $\$ 1.20$ in gold, and $\$ 1.50$ in silver. The copper content of the solid sulphide lenses is reported to be about 6 per cent.

\section{PROSPECTS OF THREEMAN MINING CO.}

Besides the producing mine at the head of Landlocked Bay the Threeman Mining Co. has several prospects at which considerable work has been done. These prospects include the ground formerly owned by the Alaska Commercial Co. on Landlocked Bay, the Montezuma claim on Copper Mountain, some claims on the south side of Landlocked Bay, and others near the summit on the Fish Bay side of the divide between Landlocked Bay and Fish Bay. These claims will be described briefly.

WORKINGS OF ALASKA COMMERCIAL CO.

The workings of the Alaska Commercial Co. are on the north side of Landlocked Bay near its head and only a short distance west of the Threeman mine. This prospect was located in 1897 by Louis Jacobson and is reported to have been the first discovery of copper ore by white men in this district. The underground development work includes a 412-foot crosscut tunnel driven in 1898-99 at an elevation of 200 feet above sea level and two shorter adits driven later that are reported to be 20 and 100 feet in length and 250 feet above the lower adit. Several tons of high-grade ore are said to have been shipped from the upper adits. Since the Threeman Mining Co. has obtained control of the property a drift has been started in the crosscut tunnel about 210 feet from the mouth of the adit. 
In 1912 and 1913 two men were employed extending this drift eastward.

The country rock of the ore deposit is chiefly greenstone, more or less ellipsoidal, with some interbedded black and gray slates and lightcolored fine-grained graywackes. The strikes and dips of the sedimentary beds vary. In the lower crosscut tunnel a strike N. $30^{\circ} \mathrm{W}$. and a dip $50^{\circ} \mathrm{E}$. was observed. Near the upper adits the strike is $\mathrm{N} .20^{\circ} \mathrm{W}$. and the dip $70^{\circ}-80^{\circ} \mathrm{E}$. In a gulch east of the upper adits, at an elevation of 400 feet, a graywacke and black slate band 40 feet or more in thickness strikes N. $5^{\circ} \mathrm{E}$. and dips $70^{\circ} \mathrm{E}$.

The ore occurs in a shear zone about 30 feet wide that carries large lenses of massive unsheared greenstone around which the sheared strips bend. The ore lies in the narrower and more sheared portions and in joint cracks in the massive lenses and the country rock. Some of the smaller sheared strips, 2 to 6 inches wide, are slightly mineralized. The adits are driven in the more highly mineralized part of the shear zone, which is a narrow band that ranges from 2 to 10 feet in width but probably averages only about 4 feet. This band strikes N. $85^{\circ} \mathrm{W}$., dips $60^{\circ} \mathrm{N}$., and is traceable about 250 feet along the strike. It extends about 75 feet west of the present adits but is not well developed. In a gulch at the east end of the known outcrop 2 feet of solid pyrrhotite has been found. In the adit tunnels a few lenses and streaks of chalcopyrite and pyrrhotite, 2 to 8 inches thick, are present. The largest lens is said to have contained a mass of solid chalcopyrite and pyrrhotite 18 inches in thickness.

The long crosscut was driven to intersect the large shear zone outcropping above, but no ore was found in the main adit. Development work in the winter of 1912-13 in the east drift in this adit exposed a foot of solid pyrrhotite but no chalcopyrite.

The ore is probably chiefly a replacement of the sheared greenstone, with some cementation of small fractures by solid sulphides. The sulphide minerals present are chalcopyrite, pyrrhotite, sphalerite, galena, arsenopyrite, and the undetermined sulphide also found at the Threeman mine. Gold and silver are reported in assays of the copper ore. The presence of galena and arsenopyrite in this ore is noteworthy. With the exception of pyrite, which was not observed in the specimens examined, the association of metallic minerals is the same as that in the gold quartz veins of the Prince William Sound region. The gangue minerals include quartz, epidote, and the products formed by the shearing and hydrothermal alteration of the greenstone.

\section{MONTEZUMA CLAIM.}

The Montezuma claim is situated on the steep south slope of Copper Mountain, a little lower and a little to the east of the workings of the Standard Copper Mines Co. The developments comprise a 
straight crosscut tunnel 350 feet long at an elevation of 1,300 feet above sea level, one short crosscut tunnel about 10 feet long, an adit of about the same length, and considerable stripping, reported to be about 900 feet in length, along the lead which outcrops. at an elevation of about 1,400 feet.

The country rock of the lead is principally greenstone with a few beds of interlayered black slate which, as exposed, have a maximum thickness of 15 feet. The ore occurs in a mineralized shear zone 20 feet wide which strikes due east and dips $65^{\circ} \mathrm{N}$. Erosion of the outcrop of this shear zone has resulted in a well-defined shallow trough, which is traceable for a considerable distance eastward toward the head of Landlocked Bay. The mineralization of the shear zone is irregular. Copper ore is reported to have been found in all the pits along the 900 feet for which the lode has been traced by the owner. The ore was formed by the impregnation and replacement of the sheared material by chalcopyrite and pyrrhotite. Some quartz accompanies the sulphides. Lenses of solid chalcopyrite and pyrrhotite 1 to 4 inches thick have been found in some of the open cuts. These sulphides also occur disseminated in the sheared material.

Actual development work on the ore body has thus far been confined to surface stripping and the two adits. The 350 -foot adit was driven to crosscut this lode but has not yet reached the main shear zone.. A small copper lead, however, is reported to have been crossed in this adit.

CLAIMS ON SOUTH SIDE OF LANDLOCKED BAY.

Four tunnels, 115, 65, 35, and 5 feet in length, have been driven on claims belonging to the Threeman Mining Co. on the south side of Landlocked Bay. These workings are located S. $45^{\circ} \mathrm{E}$. of Copper Mountain and between elevations of 450 and 650 feet above sea level. A trail leads from Landlocked Bay to the adits, which have been driven at different elevations in slightly mineralized shear zones in interbedded black slates, graywackes, and greenstones. The recorded strikes and dips of the various shear zones examined are as follows: Strike N. $75^{\circ} \mathrm{W}$., dip $40^{\circ}-50^{\circ} \mathrm{N}$.; strike N. $65^{\circ} \mathrm{E}$., dip vertical; strike N. $35^{\circ} \mathrm{W}$., dip $35^{\circ} \mathrm{N}$.; strike N. $85^{\circ} \mathrm{W}$., dip $52^{\circ} \mathrm{N}$. The stripped outcrops of the shear zones are iron stained in places, with exceptionally a little copper staining. Small lenses of quartz carrying chalcopyrite and pyrrhotite are visible in the lowermost open cut. Very little ore was found in any of the workings. Both greenstones and slates are slightly mineralized, chalcopyrite and pyrrhotite being the sulphide ore minerals.

\section{WORKINGS ON FISH BAY SIDE OF BILLY GOAT MOUNTAIN.}

The workings on the Fish Bay side of Billy Goat Mountain consist of short adits at elevations of approximately 1,150 and 1,750 feet 
above sea level. The country rock of the ore bodies is massive greenstone. The lower adit is driven 30 feet northeastward on a slightly sheared zone along a master joint which strikes N. $45^{\circ}$ E. and dips $45^{\circ} \mathrm{E}$. at the base of a 50-foot bluff of massive greenstone. The thickness of the sheared zone ranges from a fraction of an inch to 6 inches. Slight copper and iron stains appear along the shear zone, which carries a few stringers of chalcopyrite and pyrrhotite and a little quartz. The greenstone beneath the adit is much shattered and contains quartz-calcite veins, short and lenticular, the largest ones 3 feet in width and 10 to 12 feet in length.

The upper workings are in a vertical copper-stained bluff of greenstone. The adits are driven along small shear zones, which strike N. $70^{\circ} \mathrm{W}$. and dip $30^{\circ}-50^{\circ} \mathrm{N}$. The largest body of ore is reported to have been not over 8 feet long and 1 foot wide, and to have contained about 6 per cent copper. The sulphides of the ore are chalcopyrite and pyrrhotite. The ores are sulphide impregnations and replacements of the sheared greenstone.

\section{ALASKA, PIONEER, AND SOURDOUGH FRACTIONS.}

The Alaska, Pioneer, and Sourdough fractions are situated on a small point of land extending southward into Landlocked Bay between the workings of the Old Alaska Commercial Co. and Landlock. The Alaska lode wàs located by Joseph Putz and Peter Steinmetz about 1900. In 1913 all three fractions were said to belong to Peter Steinmetz. Development work at that time consisted of a 40foot adit and a 28-foot shaft close to shore, and several open cuts. Six tons of ore that contained 6 per cent copper are said to have been shipped from this ground.

Several nearly parallel ore-bearing shear zones are reported on these claims. The country rock includes greenstone, slate, and graywacke. The best mineralized shear zone which crosses the tip of the point strikes N. $64^{\circ} \mathrm{E}$. and dips $65^{\circ} \mathrm{NW}$. There is a well-defined massive hanging wall; the footwall is indefinite. The ore is reported to have occurred in bunches or lenses and to have ranged from 2 inches to 4 feet in width. The adit and shaft are on this shear zone. At an elevation of 120 feet a shear zone of indefinite width strikes approximately $\mathrm{N} .70^{\circ} \mathrm{E}$. and forms bluffs and gulches along the hillside. This shear is reported to be traceable from sea level to this elevation. The ore is irregularly distributed within the shear zone. The largest ore lens is reported to have had a length of 8 feet and a maximum width of 2 feet of ore. Chalcopyrite also occurs in joints in the hanging wall of the shear. Another shear zone which strikes N. $65^{\circ} \mathrm{W}$. and dips $55^{\circ} \mathrm{N}$. crosses the ridge at an elevation of 340 feet. It is traceable about 150 feet and forms a gulch as do many of the other shears. As exposed in open cuts it appear's to be about 
6 feet wide. This shear zone is intersected at an elevation of 320 feet by another shear zone which strikes N. $70^{\circ}$ E., dips vertically, and is traceable over 200 feet.

Chalcopyrite and pyrrhotite are the principal sulphide minerals of the ores, and quartz and calcite are the gangue minerals.

\section{HOODOO CLAIM.}

The Hoodoo claim is situated on the south shore of Landlocked Bay, a short distance east of the ore bunkers of the Landlock Bay Copper Mining Co. This claim was located January 1, 1904. Thomas B. Grove and the Threeman Mining Co. each have a half interest in it, according to report. The workings include considerable surface stripping and three adits, 180, 60, and 15 feet long, of which 105 and 45 feet, respectively, of the two longer adits were driven in slide rock. The remainder of the adits is in solid rock. A 30-foot raise has been driven to the surface in the long adit. The 60 -foot adit was driven in 1903. Two men were at work on the property in 1912.

The country rock of the ore bodies is greenstone. The last 75 feet of the long adit is driven S. $66^{\circ}$ E. on a shear zone that dips $60^{\circ} \mathrm{N}$. in the greenstone. The ore is said to have ranged from a thin film to 2 feet in thickness and to have averaged 4 to 5 per cent copper. A 30 -foot raise was put in to the surface along the footwall of this lead where it was first struck in the adit in 1910. Surface stripping at an elevation of 230 feet above sea level has exposed for about 75 feet a 3-foot band of mineralized sheared greenstone, which strikes N. $45^{\circ}$ W. and dips from $60^{\circ} \mathrm{NE}$. to nearly vertical. A network of tiny quartz veinlets shows on the iron-stained outcrop of the lode. The 15 -foot adit, 150 feet above the cabin, is driven S. $60^{\circ}$ E. on a lead reported to show 3 feet of copper ore in the face of the adit. One hundred feet east of the long adit and at the same level stripping has exposed an 18-inch shear zone in greenstone. This lode strikes N. $30^{\circ}$ W., dips $55^{\circ}$ NE., and carries a little copper.

The sulphide minerals of the ore are chalcopyrite, pyrrhotite, and sphalerite. Native copper is found in the iron-stained outcrops above the 15-foot adit. The ore carries only a small amount of copper, but assays of $\$ 10$ to $\$ 22$ in gold are reported. Quartz is an abundant gangue mineral.

CHISNA CONSOLIDATED MINES CO.

The property of the Chisna Consolidated Mines Co. is on the south side of Landlocked Bay near its head. The company is reported ${ }^{1}$ to have been promoted in April, 1909. The development work to date

1 Stevens, H. J., The copper handbook, vol. 10, p. 607, 1911. 
consists of a 40-foot inclined shaft and a few open cuts. Only assessment work has been done in recent years. A few buildings have been erected. The property is located on the trace of the Landlock overthrust fault and the ore body appears to be a slightly mineralized schistose greenstone.

\section{GOLD QUARTZ PROSPECTS.}

A few gold quartz claims have been located in different parts of the Ellamar district on stringers, lenses, and stockworks of gold-bearing quartz, but no prospects of economic importance have as yet been found. Several large low-grade quartz masses are reported on the seaward side of Bligh Island. Near the entrance to Cloudman Bay there is a stockwork of quartz veins in slate 20 to 30 feet wide, containing about equal quantities of quartz and slate. The strike is a little east of south, and the dip is $65^{\circ} \mathrm{N}$. A 4-inch gouge seam forms the south wall and two small faults with gouge were seen at the left edge. Most of the cropping is below high tide, but the lode is stripped 40 feet back from the beach. The quartz is drusy. The sulphides include chalcopyrite, pyrite, and sphalerite: The ore is reported to average $\$ 2$ to $\$ 4.80$ on samples taken across the entire 30 feet.

At the northeast corner of Bligh Island is an old prospect of the Alaska Commercial Co. on a mass of gold quartz that is said to have assayed as high as $\$ 2,500$ to the ton. The ore is reported to have been worked out. The shaft is now caved in and nothing can be seen.

In a bay at the north side of Graveyard Point Mr. L. E. Banzer has put down a couple of shafts and done several hundred feet of stripping, all now caved in and covered and the shafts full of water. The slate and the graywacke in this vicinity are much contorted" and crumpled, but the general strike seems to be a little south of east and the dip steep to the northeast. The slates have many stringers and bunches of quartz up to 6 inches thick. In the bottom of one of the shafts a lead 2 feet wide is reported. On the dump is a good deal of quartz that carries sulphides. Chalcopyrite, pyrrhotite, pyrite, sphalerite, and galena are found in the ore and a little calcite is included in the gangue. Assays as high as $\$ 50$ in gold to the ton are reported on this ore, but the samples are not known to have been average specimens.

\section{MINES AND PROSPECTS ON PORT FIDALGO.}

In 1913 B. L. Johnson made a hasty reconnaissance of the ore deposits of the region bordering Fidalgo Bay and the results are appended to this report. Acknowledgments are made to Messrs: A. H. Brooks, T. W. Blakney, W. A. Dickey, W. B. Harris, and G. E. Scott for assistance rendered in the examination of these deposits. 
Tocilion-The property of the Fidalgo Mining Co. is situated on the suxith side of Port Fidalgo, 15 miles east of Porcupine Point, at the suithern entrance to Port Fidalgo, and about 1 mile southwest of Vialen Bay. It can be reached only by boat. It is about 50 miles by water from Valdez via Tatitlek Narrows, and about 20 miles from Ellamar for boats that can pass through Tatitlek Narrows. Ellamar is the principal supply point.

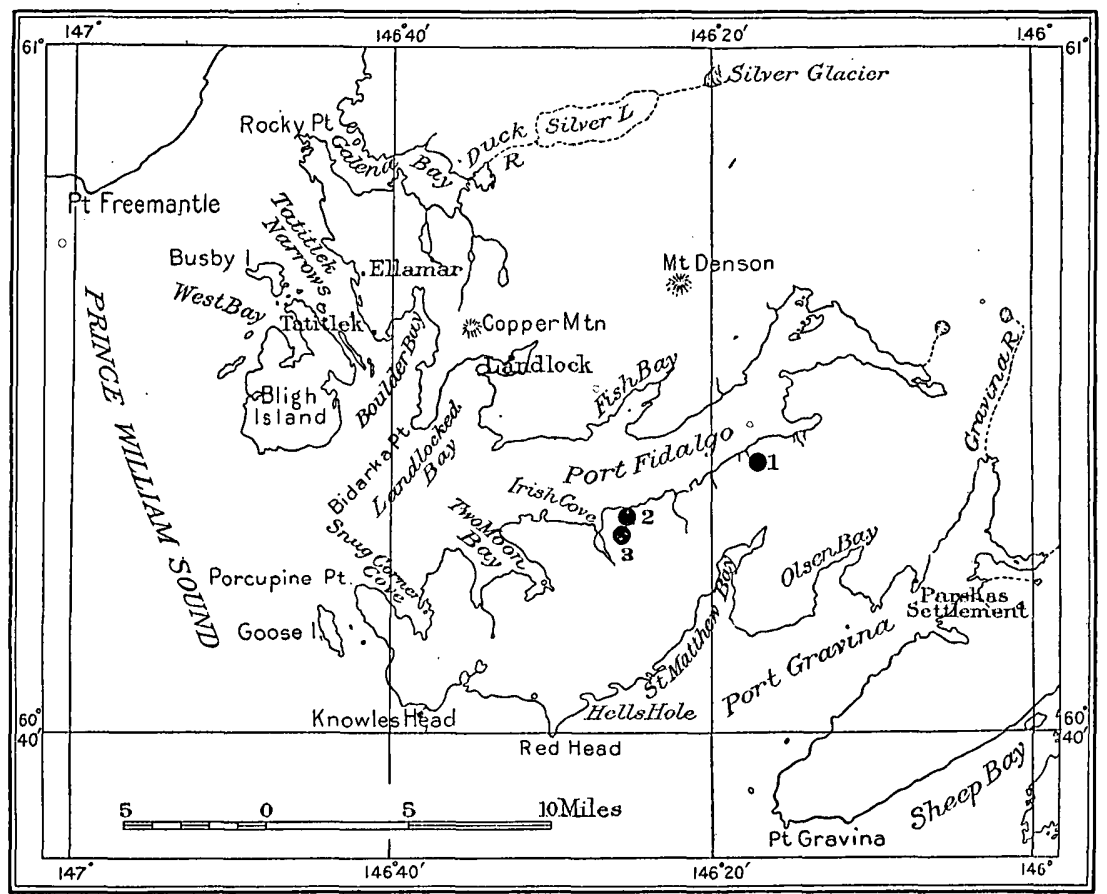

Figure 10.-Sketch map showing locations of properties of Fidalgo Mining Co., Fidalgo Alaska Copper Co., and Dickey Copper Co. on Port Fidalgo.

The property is reported to consist of a group of 24 claims. The principal underground workings are on the Winchester and Elgin claims. A trail extends to the mine workings from a cabin on the shore about 1,000 feet east of the wharf and ore. bunkers. A poorer trail extends from the lower bunkers to the mine workings. This trail parallels the tram line and joins the other trail at the bridge below the upper camp at an elevation of about 550 feet. The entrance to the lower adit is about 2,500 feet from shore, and at an elevation of abont 850 feet above sea level. Parts of the claims are wooded.

ristory and development.-This property was discovered in 1905 by 'T. W. Blakney and H. H. Herren. Mr. Blakney bought out the quarter interest held by $\mathrm{Mr}$. Herren in the fall following the discovery. 
The Fidalgo Mining Co. was incorporated under the laws of Washington in the fall of 1906 or spring of 1907, and no change in ownership of these claims has since taken place. Most of the development work was done in the summer of 1907 and consisted principally of driving the present lower adit about 400 feet. Not much else was done until the fall of 1912 and the winter of 1912-13. The aerial tram was completed early in 1913.

The main developments at present include the lower adit 450 feet long, at an elevation of about 850 feet; an upper adit 240 feet long, 100 feet above the lower adit; and a raise connecting these two adits. A 65-foot raise connecting the upper adit with the surface is reported to have been completed late in 1913. Part of the ore body between the two levels has been stoped out. The mine was operated continuously in 1913 with an average crew of 8 men, working one shift only. Shipping started in February, 1913, and several shipments were made in that year. A 40-foot adit has been driven on the Panama claim and some stripping was done long ago on the property.

Equipment and ore treatment.-The surface improvements on the property; other than the trails already referred to, consist of a wharf (reported to be 125 feet in length); ore bunkers at the landward end of the wharf; a 2,000-foot 2-bucket aerial tram connecting these lower bunkers with the bunkers and sorting house at the upper terminal of the tram; a $1 \frac{1}{2}$-story log building at 825 feet elevation, used as eating and sleeping quarters for the miners; a log blacksmith shed and a log gasoline-engine shed at the north mouth of the lower tunnel; and a log cabin and shake shed at the lower end of the trail on the shore, 1,000 feet east of the wharf. A surface tram extends westward from the mouth of the lower adit for about 900 feet to the upper terminal of the aerial tram. The upper ore bunkers are reported to hold about 50 tons, and the tram will handle, according to report, about 40 to 50 tons of ore a day. The lower bunkers are built of logs and have a shake roof. Their capacity is said to be about 500 tons of ore.

The ore is trammed from the chutes in the lower adit to the sorting house and bunkers at the upper terminal of the aerial tram. It is then sent to the main bunkers at the wharf and shipped by boat to the Tacoma smelter.

Ore deposit.-The geology of the country on the south side of Port Fidalgo has not yet been studied in detail, and the exact age of the rocks is not known nor have their relations to one another been deciphered. Presumably the greenstones are of the same age as those of the Ellamar district and at least a part of the sediments can probably be correlated with those studied in the Ellamar district. The country rock on the claims of the Fidalgo Mining Co. includes 
both sedimentary rocks and basic igneous rocks (greenstones). The igneous rocks are ellipsoidal in places and are apparently lava flows. The sedimentary rocks consist of banded bluish-gray flinty argillites, fine-grained light-gray graywackes, blue-black slates, bluish limylooking beds which weather deeply a light-brown color, and mica schist. At an elevation of about 560 feet on the trail the bedding in banded graywackes strikes N. $80^{\circ} \mathrm{E}$. and dips $65^{\circ} \mathrm{N}$. The schists have apparently been overthrust from the east into their present position. At an elevation of 1,100 feet along the lode the bedding, or possibly the schistosity developed by this overthrusting, strikes about N. $53^{\circ} \mathrm{E}$. and dips $70^{\circ} \mathrm{NW}$. The individual beds are from 4 to 8 inches apart. These schists are hard blocky beds, ranging from pale pink to reddish brown. Under the microscope biotite is seen to be the most conspicuous constituent, although in some specimens numerous small garnets, the largest 0.12 millimeter in diameter, are found. In some of the schist specimens examined a second schistosity appears to be developing at an angle to the earlier schistose structure. One schistosity would appear to have developed in the earlier overthrusting, and the other was formed during the development of the ore-bearing shear zone which cuts across the overthrust beds. Close jointing parallel to the ore-bearing shear is visible in these overthrust schists.

The ore deposit lies in a shear zone which cuts across the earlier overthrust beds. This shear zone is reported to have been actually traced for about 700 feet but to outcrop in places over a distance of 4,000 feet. The hanging wall of the shear zone appears to be principally greenstone. The footwall is in most places the hard blocky mica schist. The strike of the ore-bearing shear zone ranges from $\mathrm{N}$. $4^{\circ} \mathrm{E}$. to $\mathrm{N} .6^{\circ} \mathrm{W}$., and the dip at different points on the lode ranges from $55^{\circ}$ to $75^{\circ} \mathrm{E}$. Most of the recorded dips are between $63^{\circ}$ and $75^{\circ} \mathrm{E}$. Within this shear zone a cross shearing was observed, in greenstone in the lower adit, which strikes N. $30^{\circ} \mathrm{W}$. and dips $65^{\circ}$ NE. This shearing is said to be constant throughout the workings, does not interfere with the strike of the ore bodies, and is separated from them by good walls. There is little if any postmineral movement.

The ore-bearing shear zone forms a pronounced gulch in the mountain side which contains a stream that runs in most places against the schist footwall of the shear zone.

The width of the shear zone is from 20 to 30 feet. The ore occurs within the shear in two zones parallel to the shearing. In places in the mine these two zones practically come together, but usually they are separate. On the upper level they are from 5 to 7 feet apart; on the lower level only 2 to 3 feet apart. The rock between the two zones, usually a sheared greenstone, is in some places slightly 
mineralized. The ore-bearing streak on the footwall is reported to be as strong and persistent as that on the hanging wall but to be less well mineralized and more irregular. The footwall ore is said to have a maximum width of 3 feet and to run about 7 per cent copper at the most favorable place. The best ore yet mined on the property has come from the hanging-wall ore streak, on which a maximum width of $4 \frac{1}{2}$ feet of 14 per cent copper ore is reported to occur in a stope on the lower level.

The first 50 feet of the lower adit is a crosscut; the rest of the adit is driven along the lead. Two stopes have been started on this level on two shoots about 40 feet apart. In one the stope length of the shoot was from 30 to 40 feet, the pitch length as developed was about 90 feet, and the width ranged from 6 inches to 5 feet of solid ore. In the other shoot the stope length was 30 feet, the pitch length as partly developed was 30 feet, and the thickness of ore ranged from $1 \frac{1}{2}$ to 5 feet. In July, 1913, $2 \frac{1}{2}$ feet of ore was visible in the top of this stope. The distribution of ore within this shoot is said to have been rather irregular and bunchy.

The upper adit is driven along the shear zone for most of its length between the two ore streaks previously mentioned. In July, 1913, the upper adit was being advanced along the footwall streak of ore, which at that point, about 150 feet from the adit mouth, showed about 3 feet of good ore. The solid sulphide ore in the upper tunnel is reported to be of lower grade than that in the lower adit, probably because pyrite is more abundant in the ore of the upper tunnel. About 160 feet above this adit, however, 3 feet of highgrade ore lies along the footwall of the shear zone. Chalcopyrite ore also occurs in the shear at an elevation of 1,300 feet.

The metallic minerals in the ore include chalcopyrite, pyrite, and pyrrhotite. Chalcopyrite is the most abundant sulphide and is the source of the copper obtained from this ore. Pyrite is abundant. The pyrrhotite is present in very small amounts and this scarcity of pyrrhotite appears to be characteristic of these Port Fidalgo ores. A low gold content of from 50 cents to $\$ 1$ a ton is reported but no silver. Sphalerite, which occurs in the other Port Fidalgo properties visited, was not seen in the specimens examined from this property but may be present. The average copper content of the ore shipped in 1913 is reported in a recent article ${ }^{1}$ to have been a little over $8 \frac{1}{2}$ per cent. Very little copper stain is seen on the outcrop of the ore body, but iron staining is conspicuous. The gangue minerals of the ore include the country rock and a little quartz. This country rock appears to be chiefly sheared greenstone. Pyrite impregnates the schist to a slight extent, but the copper appears to be chiefly associatèd with the sheared greenstone.

1 Blakney, T. W., Fidalgo Mine, Fidalgo Bay, Alaska: Pacific Min. Jour., August, 1913, pp. 23-24. 
The sulphide mineral association at this deposit is that characteristic of the primary ore deposits of this region. Very lit.tle secondary alteration has taken place and appears to have been confined to a little surficial development of copper carbonates and limonite on the outcrop of the ore body. The sulphide ore is chiefly a replacement by the sulphide minerals of the crushed material of the shear zone and possibly partly the cementation of small openings in the sheared and shattered rocks by these same sulphides. A close association of the ores with the sheared greenstone is noted. Most of the conclusions reached regarding the genesis of the ores of the Ellamar district appear applicable to this ore deposit.

\section{FIDALGO-ALASKA COPPER CO.}

Lacation.-The property of the Fidalgo-Alaska Copper Co., better known in the Prince William Sound region as the Schlosser property, is situated on the south side of Port Fidalgo, about one-half mile east of Irish Cove and about 10 miles east of Porcupine Point at the southern entrance to Port Fidalgo. This property is ordinarily reached by water. It is about 43 miles by water from Valdez by way of Tatitlek Narrows and a little farther by the route outside of Bligh Island used by the steamers. The distance to Ellamar for small boats that can pass through Tatitlek Narrows is about 15 miles. Cordova is 55 miles distant.

The underground workings lie between elevations of 825 and 1,100 feet above sea level, on a northward-facing timbered slope, and about 2,500 feet from the beach. A trail connects the mine workings with the wharf. The property is timbered.

History and development.-This property is said to have been discovered in the later part of June, 1907, by Charles Schlosser. The Fidalgo-Alaska Copper Co., an Alaskan corporation, was then formed. Development started in the fall of 1907 and considerable work has since been done. The property was idle during the summer of 1913, but in the fall of that year work was again started and a small shipment of ore to Tacoma is reported to have been made. Several hundred tons of ore are reported to hare been previously shipped.. The important underground developments at the time of the writer's visit included the lower tunnel, at an elevation of 825 feet, which has about 550 feet of crosscuts and drifts, one large and one small stope, and a raise of unknown height; one small stope parallel to the main adit and 5 feet east of it; and an adit at an elevation of 950 feet that forks at the mouth. The west branch is 75 feet long; the east branch has about 500 feet of work with a raise of unknown height. At an elevation of 1,005 feet a short adit forks 45 feet from its mouth into two branches 10 and 15 feet long, respectively. At an elevation of 1,050 feet two shallow shafts have been sunk, one of which extends down to the west branch of the adit at 1,005 feet elevation. 
A 15-foot adit has also been driven at 1,030 feet above sea level. A winze has been started in this adit.

At an elevation of 1,080 feet there is a 5 -foot shaft and a 40 -foot adit. Fifty feet below this to the west lies a short adit 6 to 8 feet long. A large amount of stripping and open-cut work has also been done on the property.

Equipment and ore treatment.-The surface improvements on the property include the trail from the wharf to the mine workings, a wharf, ore bunkers at the landward end of the wharf, a two-story frame building close to the ore bunkers, an aerial tram, reported to be a little over 2,800 feet long, from the wharf to the mine, and several log buildings, including cook and bunk house, and a blacksmith shop at the mine workings. A portion of the wharf was washed away in the summer of 1913.

The ore is sent from the mine workings, over the aerial tram, to the ore bunkers at the wharf for storage awaiting shipment to the Tacoma smelter.

Ore deposit.-The country rock in the vicinity of the ore deposit on the claims of the Fidalgo-Alaska Copper Co., so far as could be seen when the property was visited, consists entirely of sedimentary rocks, nor are any igneous rocks reported. These sedimentary rocks consist chiefly of interbedded thin-bedded and fine-banded light to dark gray siliceous rocks ranging from fine-grained graywackes through argillites to cherty aphanitic, bluish to darkgray siliceous rocks. Black slates occur and in one ore specimen chalcopyrite replaces dark-gray limestone. Little evidence of bedding is seen near the ore deposit. At the wharf in an interbedded series of slates, argillites, and graywackes the bedding, plainly seen, strikes N. $27^{\circ} \mathrm{W}$. and dips $55^{\circ} \mathrm{W}$.

This sedimentary series has been closely folded and sheared. There appear to be two sets of shearing, the relative ages of which are as yet undetermined. One set has a northeast to due east strike, paralleling in a general way the trend of Port Fidalgo. Certain parallel gulches in the ridge east of the ore deposit probably mark fissures of this set. The other set has a northerly strike and a steep easterly or westerly dip. The mineralization appears to be restricted to this set of fissuring. The lower tunnel is started on a sheeted zone in graywacke, the joints of which strike N. $10^{\circ}-20^{\circ}$ E. and dip $55^{\circ}-65^{\circ}$ W. At 940 feet above sea level the strike of the shearing in closely sheared slates is $\mathrm{S} .86^{\circ} \mathrm{E}$. and the dip $55^{\circ} . \mathrm{N}$. At an elevation of 950 feet there are two sets of shearing; one of these strikes N. $50^{\circ} \mathrm{E}$. and dips $80^{\circ}$ SE. and the other strikes east and dips $75^{\circ} \mathrm{N}$. At 1,030 feet elevation a shear that strikes N. $14^{\circ} \mathrm{E}$. and dips vertically was observed and the eastward-striking shear was also noticeable. A good joint wall traceable for 15 feet strikes N. $23^{\circ}$ E. in the $45-$ foot adit at an elevation of 1,005 feet. At the mouth of this adit 
master joints in massive sheared black slate strike N. $21^{\circ}$ E. and dip $85^{\circ}$ E. At an elevation of 1,050 feet two shafts have been sunk on a curving shear. The strike of the shearing curves from N. $25^{\circ} \mathrm{E}$. to N. $4^{\circ} \mathrm{E}$. at the points where it was measured. The dip was $65^{\circ} \mathrm{E}$. At an elevation of 1,080 feet shearing in a 40 -foot adit on the west side of the ridge strikes $\mathrm{N} .40^{\circ} \mathrm{E}$. and dips $70^{\circ} \mathrm{W}$. On the north side of the ridge at the same elevation the shearing parallel to the shore of Port Fidalgo is noticeable.

The ores occur within a broad crushed zone, apparently from 150 to 200 feet wide, of closely folded, sheared, and shattered sedimentary rocks. This zone is traceable up the slope of the hill from about 825 feet to 1,100 feet above sea level. As noted above, two sets of fissuring are visible, the northward-trending system alone appearing mineralized. The ores are partly the cementation of fractures and joint cracks, partly impregnations of the rocks of the ore zone, and partly replacements of some of the rocks. At the mouth of the lower tunnel an irregular network of small quartz veins cements a shattered graywacke. In some places the sulphides fill the joint cracks; at others they are disseminated through the rocks. In one specimen examined chalcopyrite replaces a sheared dark-gray limestone. A peculiar feature of some of the ore on this property, as well as on the Mason \& Gleason claims, is the filling by chalcopyrite, pyrite, and quartz of irregular"small tubular wormlike channels in the sedimentary rocks.

Several hundred tons of ore are reported to have been shipped from the property, but the dimensions of the ore bodies from which this ore came or the copper content of the ore are not known. The only stopes seen were those in the lower adit and the one between the tunnel at 1,005 feet elevation and the surface, where excavations show the remains of an ore shoot, about 6 feet wide and 10 to 15 feet long, extending down about 40 feet to the adit level. Many of the individual ore-bearing shears seen were not very extensive.

The metallic minerals in the ore comprise chalcopyrite, pyrite, pyrrhotite, and sphalerite. Chalcopyrite and pyrite are the predominant sulphides. Chalcopyrite appears to be the only copperbearing mineral present in the ore. Pyrrhotite is scarce and sphalerite was observed in but one specimen picked up on the dump, but it was abundant in this specimen. A scarcity of pyrrhotite and an abundance of pyrite appear to be characteristic of these Port Fidalgo copper deposits. Pyrite usually occurs as tiny crystals. The gold and silver content of the ore is not known. The gangue minerals introduced contemporaneously with the sulphide minerals consist of a. very small amount of quartz and calcite. Some of this calcite may be a recrystallization of sedimentary limestone by the orebearing solutions. A close association of the chalcopyrite and quartz is noted in several places where both occur. Very little surficial 
alteration of the primary ores has taken place, and consequently there is no appreciable amount of enrichment.

The sulphide minerals at this deposit correspond to those of the other primary ore deposits of the Prince William Sound region. The ores are chiefly replacements of shattered and sheared sedimentary rocks and partly the cementation of small fractures or joint cracks in these rocks by the same sulphides. Most of the conclusions reached regarding the genesis of the ores of the Ellamar district appear applicable to this ore deposit.

\section{DICKEY COPPER CO.}

Location.-The claims of the Dickey Copper Co., better known as the Mason \& Gleason claims, are situated on the south side of Port Fidalgo, a short distance east of Irish Cove and perhaps one-half mile from the south shore of Port Fidalgo. The landing point for the claim, on the east shore of Irish Cove near its head, is about 14 miles from Ellamar by way of Tatitlek Narrows. The mine workings are reached in about 45 minutes by a trail approximately 2 miles long, which starts from a small shake warehouse at the shore, follows southeastward along the base of a timbered ridge for nearly a mile, swings eastward around the ridge, and then doubles back northward through the timber along the east slope of the ridge to the claims. The lower adit is at an elevation of about 470 feet above sea level. The claims are timbered, mostly with hemlock but with some spruce. The property is reported to consist of nine claims.

History and development.- This property is reported to have been discovered by George Mason and Mark Gleason in July, 1907. The Black Bear claim was located by them July 18 of that year. The dates of the discovery and location of the other claims of this group are not known to the writer. The property was bonded in the fall of 1910 to W. A. Dickey, who later bought it. The Dickey Copper Co. is the present owner. About 50 feet of underground development work is reported to have been done prior to the bonding of the property to Mr. Dickey. Some development work was done in 1911 and 1912. In the spring of 1913 , when four men were at work on the property, the trail was made, ore bunkers were built, 110 feet of tunnel and 70 feet of drift were driven, and about 600 tons of ore was mined. At the time the property was visited operations had been temporarily discontinued. No ore shipments had been made to that date.

The underground developments on the property in July, 1913, included the lower adit, at an elevation of about 470 feet, containing approximately 500 feet of drifts and crosscuts and a raise; an upper adit 125 feet long, at an elevation of 540 feet, with a raise of about 25 feet, and a stope 30 by 8 feet extending from the adit up to the 
surface; an intermediate adit 35 feet long between the upper and lower adits; a 30 -foot winze with a slope of $42^{\circ}$ connecting the upper and intermediate levels; and a short crosscut tunnel on the outcrop of the lead at an elevation of about 570 feet.

Equipment and ore treatment.-The surface improvements on the property, besides the trail already mentioned, consist of a small shake warehouse on the shore of Irish Cove; a cabin below the mine workings at an elevation of about 340 feet; two log ore bunkers that have a total capacity of about 800 tons, just below the mouth of the lower adit; two shake sheds at the mouth of the lower adit; a log blacksmith shop and a small log ore shed at the mouth of the upper adit; and a mine car and rails in the lower adit. The ore thus far mined, reported to be between 600 and 700 tons, is stored in the ore bunkers.

Ore deposit.-The country rock seen on this property was entirely of sedimentary origin. No igneous rocks were seen and none are reported in this neighborhood. The country rock of the ore deposit consists of an interbedded series of thin-bedded siliceous rocks grading from graywackes to argillites and slates. No limestones were definitely recognized, although the character of some of the ores suggests that they may be replacements of limestones interbedded with the other sediments, as in similar deposits examined. Some blocky slate occurs in the upper tunnel. The thickness of the individual slate or graywacke beds is not readily determinable on account of the shattering and shearing which the rocks in the immediate vicinity of the ore deposit have undergone. Graywacke beds are not very large or abundant. West of the gulch which limits the main shear zone to the west the interbedded graywacke beds ranged from one-half inch to 4 inches in thickness. Much of the series consists of fine-banded layers of light to dark gray siliceous or argillaceous material. The general tone of the rocks is dark'gray.

This sedimentary series has been closely folded, sheared, and crushed along a zone whose western limit appears to lie along the gulch just west of the ore body. The rocks on both sides of this gulch seem to be of the same general lithologic character but are much less disturbed on the west side of the gulch than on the east side. This gulch fissure is reported to be traceable for a mile or more, but the extent of the ore-bearing zone has been thus far actually traced by the underground developments for a distance of about 300 feet along the strike. The width of the ore-bearing zone is not definitely known. The copper shoot in the upper adit was 6 to 8 feet wide, but the maximum width of the mineralized zone is probably much greater. This ore zone is reported by $\mathrm{Mr}$. Dickey to strike N. $36^{\circ} \mathrm{E}$. Individual shear zones are not usually traceable in the workings for any considerable distance. The strikes of a number of shear zones on the property ranged from N. $64^{\circ} \mathrm{E}$. to N. $41^{\circ} \mathrm{W}$. The greater number 
lay between due north and N. $50^{\circ}$ E., apparently paralleling in general the strike of the main shear zone. In the upper adit the shearing is more or less continuous, but in many places branching and reuniting farther along. Readings on the shearing in the rocks west of the ore body gave strikes of N. $9^{\circ} \mathrm{E}$. and N. $6^{\circ} \mathrm{E}$., with dips of $80^{\circ} \mathrm{E}$. and $47^{\circ} \mathrm{E}$., respectively. The strike of the bedding in these rocks appeared to be closely parallel to the shearing.

There has been a little postmineral movement, which has developed slickensides on some of the sulphide masses.

The ore occurs in the crushed zone of sedimentary rocks referred to above. The distribution and character of the mineralization is irregular. A large copper shoot was found in the upper adit and was stoped to the surface. This shoot was also reported to have been cut on the intermediate level. The ore in the face of the upper adit, in the outcrop tunnel, and some of the ore from the intermediate level carried considerable gold. The difference in the relative abundance of the ore minerals present in different parts of the ore body is marked. As at Ellamar, the gold and copper ores are more or less distinct. Chalcopyrite, the source of the copper, commonly occurs, nearly pure, in solid fine-grained masses. In some places it has impregnated and replaced certain of the narrow beds. The ores that contain the most gold are those that carry abundant fine-grained sphalerite or those in which cherty siliceous rocks have been minutely shattered and recemented by a fine network of sulphide-bearing quartz veins accompanied by silicification of the inclosed rock and its impregnation with sulphides. Chalcopyrite is not abundant in either of these types of ore. Certain of the ores carry the sulphides in irregular tubular wormlike forms similar to those seen in some of the ore from the Schlosser property.

The metallic ore minerals are chalcopyrite, pyrite, sphalerite, and pyrrhotite. Pyrite ând chalcopyrite are abundant. Chalcopyrite was the only primary copper-bearing mineral observed in the ore, and is the source of the copper. Sphalerite is abundant in some parts of the ore body. It appears to be more common at this property than at the other two properties examined on Port Fidalgo. It is usually very fine grained and appears most abundantly in association with pyrite. Pyrrhotite is not very common, a feature which appears to be characteristic of these Port Fidalgo ores. Considerable gold is reported from parts of the ore body. The gangue minerals include a small amount of quartz and calcite, introduced into the rocks contemporaneously with the sulphides.

The mineral association at this ore deposit is characteristic of the primary ore deposits of the Prince William Sound region, and most of the conclusions reached regarding the genesis of the ores of the Ellamar district appear to be applicable here. 


\section{IND́EX.}

A. Page.

Acknowledgments to those aiding ........ 87,112

Alaska claim, description of............. 110-111

Alaska Commercial Co.'s mine, description

ores of.

of ....................... 107-108

B.

Banta \& Cameron prospect, description of.. 98 Bibliogmphy of Prince William Sound ..... 52-61 Billy Goat Mountain, copper on ........... 109-110

Bligh Island, gold on .................. 112

Bonanza mine, discovery of............... 13

ores of........................... 60

Bottle Creek, features of .................. 17

Brewer, W. M., on Ellamar mine .......... 54

Brooks, A. H., on Alaskan metallogenetic epochs....................... 85-86

on origin of ore deposits............. 82-83 on Prince William Sound copper deposits...................... 56,57,61 preface by ....................... 7-8

Butler, B. S., on age of copper deposits...... 86

\section{C.}

Capps, S. R., on general geology............ 25-49 on geography of district............. 14-25 work of . ......................... 13

Chisna Consolidated Mines Co.'s claim, description of .................. 111-112

Chugach Range, history of ............... 29-30

Climate, character of ................... 19-23

Coast line, character of ..................... 15

Conglomerate, character of................ 42-43 distribution of....................... 42

Copper Crown claim, description of........ 101

Copper deposits, character of.............. $66-67$

distribution of........................ 51

mines on, description of............. 87-112

ores of.............................. 54-61 genesis of..................... 59,60-61

source of $\ldots \ldots \ldots \ldots \ldots \ldots \ldots \ldots \ldots \ldots .80-82,86$

See also Ore deposits.

Copper mining, development of ............ 13-14

Copper Mountain, copper deposits on ...... 53,58, 98, 103-106, 108-109

gold lodes on.

56
$20-21$

Cordova, climate at...................... 20-21

D.

Dickey claims. See Threeman Mining Co.

Dickey Copper Co.'s claims, description of. 120-122

history of ....................... 120-121

ore body and ores of .................. 121-122

Dikes, occurrence of..................... 48-49

Drainage, description of .................. 17-18

Duck River, features of.
E.

Page.

Ellamar, climate at ..................... 23

Ellamar mine, description of ............. 87-92

discovery of ....................... 13

history of ....................... 87-88

ore body of....................... $90-91$

ores of......... $52,53,54,55,57,59,60,61,91-92$.

plan of.......................... 89

Emerson, B. K., on Prince William Sound copper deposits. $53-54$

\section{F.}

Falck, L. P. M., prospects of ............ 103-104

Faults, age of ......................... 63-64

distribution of...................... 62-63

relation $c f$, to ore deposits........... 64, 78-79

to structure..................... 63

types of ............................ 63

See also Fissure systems.

Fidalgo Mining Co.'s claims, description of. 113-117

history......................... 113-114

map of........................... 113

ore body and ores.................. 114-117

Fidalgo-A laska Copper Co.'s claim, description of.................... 117-120

history of ......................... 117-118

ore body and ores of............... 118-120

Fielder \& Hemple prospect, description of ... 98

Fish Bay, copper near................. 109-110

Tissure systems, strike of................. 64

strike of, chart showing............... ' 64

Fleming Spit, ores at................... 53

Fort Liscum, climate at.................. 21-22

G.

Galena Bay, copper deposits at........... 55, 98

Galena Bay Mining Co.'s prospects, descrip-

tion of ................... 98-102

history of ............................ $98-99$

map of .......................... 99

ore bodies and ores of ................ 99-102

Game, abundance of...................... 25

Geography, description of ............... 14-25

Geologic history, outline of ................ 26-30

Geologic map......................In pocket. comment on ......................... 26

Geology, account of ...................... 25-49

Glaciation, effect of, on ore deposits......... 68 effect of, on topography................ 16

history of .......................... 29-30

occurrence and character of............ 46-47

Glacier Island, gold lodes on............... 50

Glaciers, erosion by ..................... 46-47

Gladhangh mine. Sec Ellamar mine.

Gold lodes, occurrence of. ............. 51,56,112

Granitic rocks, age of ..................... 82-83 intrusion of.......................... 29 mineralization and................. 8 79-86 
Grant, U. S., on Orca and Valdez groups.... 44-45 on peneplains...................... 15-16 on Prince William Sound copper depos-

its................... 54-56,58-59

Grant, U. S., and Higgins, D. F., jr., on Prince William Sound copper deposits............... 57-58,59-61

Graton, L. C., on Prince William Sound copper deposits...................

Gravels, extent of

Graywacke-slate series. See Slate-graywacke series.

Greenstones, character of............ 38,40-42,49

copper deposits in...............65,80-81

deposition of ..................... 28,39-40

distribttion of......................... 40

relations of . ...................... $38-40,42$

figure showing.

H.

Hemple Copper Co.'s claims, description of. 106-107 ores of ........................ 57-58, 107

Higgins, D. F., jr., and Grant, U. S., on Prince William Sound copper deposits................. 57-58,59-61

Hoodoo claim, description of .............. 111

\section{T.}

Igneous rocks, character and distribution of.. 48-49 Intrusive rocks. See Granitic intrusive rocks.

J.

Johnson, B. L., on mineral resources . . . . . . 50-86 work of. $7-8,13,112$

K.

Keystone claim. Sce Threeman Mining Co.

I.

Lagoon Creek, features, of

Landlocked Bay, copper deposits on...... 52-57, 92-97, 102-112 discovery of .

Landlock Bay Copper Mining Co.'s mine, de scription of 96-97 ore body and ores of ................. 97 plan of........................... 97

Landlock fault, location and character of. 33-34,62 Leacining, ore deposits due to............... 81 Lindgren, Waldemar, on metallogenetic epochs .......................... 84-85

Literature of Prince William Sound ......... 52-61

Location of Ellamar district ............... . 9 map showing........................ 10

\section{M.}

Map, geologic comment on. In pocket.

Mason \& Gleason claims. See Dickey Copper Co.

Mertie, J. B., jr., on igneous rocks of district. Metallogenetic epochs and provinces, Ellamar district and.
Page.

Metals of district, list of. . ................ $\quad 50$

Mineral deposits. See Ore deposits.

Mineralization, depth of .................. 75,76 period of. . ................... $73-75,82-86$ unity of ........................ $74-75,86$

Mineralogy of ore deposits ............. 59,68-71

Mines and prospects, description of ........ 87-112 Moffit, F. H., on Prince William Sound cop-

per deposits................ 57

Montezuma claim, description of . ........ 108-109

o.

Orca, climate at...................... 20

ore deposits near...................... 60

Orca group, age of ....................... 45-46

character of . . . . . . . . . . . . . . . . . . . $36-44$

deposition of . . ....................... 27-29

distribution of...................... 35-36

faulting in........................ 65,66

mineral deposits and.................. 65

relation to Valdez group.............. 44-45

structure of......................... 44-45

Ore-bearing solutions, composition of....... 78

leaching by......................... 81

source of. ........................... $79-80$

Ore deposits, character of................ 66-68

effect of glaciation on .................. 68

minerals of ...................... $59,68-71$

genesis of....................... $73-86$

paragenesis of ............... 59, 71-72

relations of, to faults.............. $64,78-79$

to granitic intrusive rocks ... 8, 79-82, 83-84

structural relations of ................ $62-64$

See also Copper.

Ores, deposition of. . .................. $75-78$

P.

Peneplain, evidence for................. 15-16

Pioneer claim, description of. . .......... 110-111

Population, statistics of . .................. 24-25

Port Fidalgo, copper deposits at... 50-51, 112-122

Port Wells, fossils from localities near....... 45-46

Prince William Sound region, copper belt in. $\quad 50$ gold belt in......................... 50 granitic intrusive rocks of. . ............ 83-84 investigations in ................. 7-8, 9-13 mineral belts of....................... 50

literature on..................... 52-61

relation of to district.............. 50-51

mineralization in, periods of .......... $73-75,84$

Q.

Quaternary deposits.................. 47-48

R.

Relief, description of ................... 14-16

Replacement, evidences of .............. $76-78$

Reynolds Alaska Development Co.'s claims, description of.............. 102-103

ores of.. $, \ldots \ldots \ldots \ldots \ldots \ldots \ldots \ldots .57,61,102-103$

Reynolds Creek, features of.............. 18

Ripstein ledge, ores of .................. 53

Rock formations, descriptions of........... 30-49 sequence of........................ $26-30$ columnar section showing .......... $\quad 27$ 
s.

Schlosser property. See Fidalgo-Alaska Copper Co.

Schrader, F. C., on Prince William Sound copper deposits............. 52-53

Schrader, F. C., and Spencer, A.C., on Prince William Sound copper deposits..

Seward-Sunrise district, minerals of .........

Sheep Run claim, description of........... 101

Slate-graywacke series, lower, character of... 37-39

Slate-graywacke series, upper, character of... $43-44$

Slates, lower, character of................ 37

Solutions, ore-bearing, composition of...... 78 source of .......................... $79-80$

Sourdough claim, description of ........... 110-111

Spencer, A. C., on ore-bearing solutions..... $79-80$

Spencer, A.C., and Schrader, F.C., on Prince William Sound copper deposits. . 53

Standard Copper Mines Co.'s mine, descrip-

tion of ................... 104-106

ores of........................... 104, 106

Starvation claim, workings of........... 99-101

Stevens, Blamey, on Prince William Sound copper deposits

Stratigraphic succession in Ellamar district. $\quad 27$

Streams, description of ................. 17-18

Structure, topography and.............. 16-17

Sulphide ores, distribution of............. 67-68

paragenesis of....................... $71-72$

Sunnyside claim, description of ......... 101-102

Sunrise formation, correlation of............ $30-31$
T.

Page.

Threeman Mining Co.'s mines, description of .................. 92-96, 107-110

history of ....................... $92-93$

ore body and ores of..... 56-57,61,94-96,108-110 analysis of ..................... 95

plan of .......................... 93

Timber, distribution of .................. 23-24

distribution of, map showing........... 24

T'opography, description of .............. 14-16

rock structure and . .................. 16-18

Trausportation, means of............... 18-19

\section{$\mathrm{V}$.}

Valdez district, minerals of ............... 74

Valdez group, character of .............. 31-32,34 correlation of ................... 30-31,34-35 deposition of ...................... 20 distribution of ..................... 26-27,30-31 relation of, to Orca'group............. 44-45 structure of........................ 33-34

Vegetation, character of .................. 23-24 Vesuvius claim, workings on........... 100-101

W.

Water, transportation by ............... 18-19

Weed, W. H., on Prince William Sound copper deposits.............. 57

Wells, R. C., on analysis of ore of Keystone claim..................... 95-96 